GA-A16000

UCT

\title{
NONDESTRUCTIVE EXAMINATION OF 51 FUEL AND REFLECTOR ELEMENTS FROM FORT ST. VRAIN CORE SEGMENT 1
}

\author{
by \\ C. M. MLLER and J. J. SAURWEIN
}

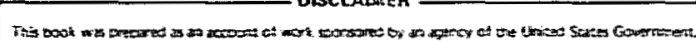

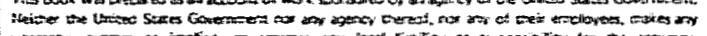

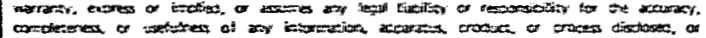

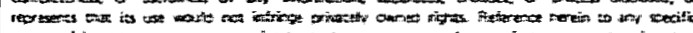

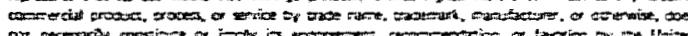

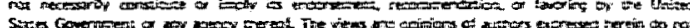

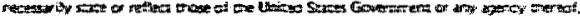

\author{
Prepared under \\ Contract DE-AT03-76ET35300 \\ for the San Francisco Operations Office \\ Department of Energy
}

\begin{abstract}
GENERAL ATOMIC PROJECT 6400 DATE PUBLISHED: DECEMBER 1980
\end{abstract}




\section{DISCLAIMER}

This report was prepared as an account of work sponsored by an agency of the United States Government. Neither the United States Government nor any agency Thereof, nor any of their employees, makes any warranty, express or implied, or assumes any legal liability or responsibility for the accuracy, completeness, or usefulness of any information, apparatus, product, or process disclosed, or represents that its use would not infringe privately owned rights. Reference herein to any specific commercial product, process, or service by trade name, trademark, manufacturer, or otherwise does not necessarily constitute or imply its endorsement, recommendation, or favoring by the United States Government or any agency thereof. The views and opinions of authors expressed herein do not necessarily state or reflect those of the United States Government or any agency thereof. 


\section{DISCLAIMER}

Portions of this document may be illegible in electronic image products. Images are produced from the best available original document. 


\section{ABSTRACT}

Fifty-one fuel and reflector elements irradiated in core segment 1 of the Fort St. Vrain High-Temperature Gas-Cooled Reactor (HTGR) were inspected dimensionally and visually in the Hot Service Facility at Fort St. Vrain in July 1979. These inspections were performed by a robotic device developed by General Atomic Company (GA) in a fraction of the time and at a fraction of the cost required for conventional inspection methods.

Time- and volume-averaged graphite temperatures for the examined fuel elements ranged from $400^{\circ}$ to $750^{\circ} \mathrm{C}$. Fast neutron fluences varied from $0.3 \times 10^{25} \mathrm{n} / \mathrm{m}^{2}$ to $1.0 \times 10^{25} \mathrm{n} / \mathrm{m}^{2}$ (E $\left.>29 \mathrm{fJ}\right)_{\text {HTGR }}$. Near1y all of the examined elements shrank in both axial and radial dimensions. The maximum average shrinkages observed for the elements were $1.85 \mathrm{~m}(0.073 \mathrm{in}$.) in the length and $0.79 \mathrm{~m}(0.031 \mathrm{in.})$ across opposing side faces. These shrinkages correspond to axial and radial strains of $0.23 \%$ and $0.22 \%$, respectively. The maximum bow observed was $0.30 \mathrm{~mm}(0.012 \mathrm{in.})$. A11 of the elements were in good condition. No cracks were observed on the element surfaces. With the exception of two large chips (both noted during preirradiation visual inspections), all blemishes observed were surface markings only.

The measured data were compared with strain and bow predictions obtained from SURVEY/STRESS, a computer code that employs viscoelastic beam theory to calculate stresses and deformations in HTGR fuel elements. Differences between measured and predicted strains were sma11: 1ess than 0.002 in./in. for radial strain and $0.0045 \mathrm{~mm} / \mathrm{mm}$ for axial strain. Differences between measured and predicted bow were also small: less than $0.40 \mathrm{~mm}$. The maximum predicted bow was about $0.50 \mathrm{~mm}$ and the maximum observed bow was $0.30 \mathrm{~mm}$ : 
Although the measurements and predictions are in agreement, in that small dimensional changes and bow were both predicted and measured, some discrepancies were observed:

1. As a group, the axial strains in elements having time-averaged irradiation temperatures less than about $550^{\circ} \mathrm{C}$ were significantly (at the $90 \%$ confidence leve1) overpredicted.

2. The variation in axial strain with temperature was overpredicted.

3. There was very little correlation (correlation coefficient $\approx 0.15$ ) between measured and predicted bow.

These discrepancies are apparently the result of inaccuracy in the design curves that define the irradiation-induced axial strain at low irradiation temperatures and fast neutron fluences. Very little low temperature, low fluence design data are available.

Because they are so small, the differences between the measurements and predictions have no significant effect on the acceptability of the performance of the fuel elements. As to the accuracy of the SURVEY/STRESS calculations, more in-pile data over a wider range of irradiation temperatures and fast neutron fluences are required before overall conclusions can be made. These data will be obtained from future inspections of FSV reload segments. 
CONTENTS

ABSTRACT . . . . . . . . . . . . . . . . . . . . .

1. INTRODUCTION . . . . . . . . . . . . . . . . . . . 1-1

2. DESCRIPTION OF METROLOGY ROBOT . . . . . . . . . . . . . . 2-1

3. DESCRIPTION OF METROLOGICAL AND VISUAL INSPECTIONS . • . • • 3-1

4. ROBOT PERFORMANCE . . . . . . . . . . . . . . . . . . . 4-1

5. RESULTS OF METROLOGICAL INSPECTIONS . . . . . . . . . . . . 5-1

5.1. Measured Strain and Bow .............. . 5-1

5.2. Comparisons of Measured and Calculated Strains and
Bow . . . . . . . . . . . . . . 5-3

6. VERIFICATION OF METROLOGY ROBOT MEASUREMENTS . . . . . . . . 6-1

7. VISUAL INSPECTION . . . . . . . . . . . . . . . . 7-1

7.1. Stains . . . . . . . . . . . . . . . . 7-1

7.2. Rub Marks .................... . . 7-1

7.3. Interface Marks .. . . . . . . . . . . . 7-2

7.4. Soot Deposits ................ . . 7-2

7.5. Side Face C Scratch or Stain . . . . . . . . . . 7-3

7.6. Fingerprints . . . . . . . . . . . . . 7-3

7.7. Chips of Chamfers and Scraped Corners ......... 7-3

7.8. Top Surface Dowels . . . . . . . . . . . . . . 7-4

7.9. Top Surface Circle Around Fuel-Handling Hole . . . . 7-4

7.10. Painted Letters and Numbers on Top Surface . . . . . . 7-4

8. ACKNOWLEDGMENTS . . . . . . . . . . . . . . . . . . 8-1

9. REFERENCES . . . . . . . . . . . . . . . . . . 9 9-1

10. TABLES . . . . . . . . . . . . . . . . . . . 10-1

11. FIGURES . . . . . . . . . . . . . . . . . . . 11-1 


\section{INTRODUCTION}

Fron July 6 through August 1, 1979, dimensional measurements and visual examinations of 51 fuel and reflector elements from core segment 1 were conducted in the Hot Service Facility (HSF) at Fort St. Vrain (FSV). The inspected elements included all 42 fuel blocks from region 17, half-sized top and bottom reflectors from region 17 , two fuel blocks from region 5, and one fuel block from each of regions $22,24,25,27$, and 30 . Time- and volume-averaged graphite temperatures for the examined fuel elements ranged from $\sim 400^{\circ} \mathrm{C}$ to $750^{\circ} \mathrm{C}$ and element average fluences ranged from approximately $0.3 \times 10^{25} \mathrm{n} / \mathrm{m}^{2}$ to $1.0 \times 10^{25} \mathrm{n} / \mathrm{m}^{2}(\mathrm{E}>29 \mathrm{fJ})_{\text {HTGR }}$. Five of the fuel blocks and the two reflectors were surveillance elements. These elements, readily recognized by the fiducial holes drilled in their corners, were extensively characterized prior to irradiation (Ref. 1), A summary of the segment 1 surveillance is given in Table $1-1^{*}$. These inspections were performed by a robotic device developed by General Atomic (GA) in a fraction of the time and at a fraction of the cost required for conventional inspection methods. The data obtained from these inspections of core components are used to monitor the performance of graphite blocks in the core and for verification of HTGR design methods.

${ }^{*}$ Tables and Figures appear in Sections 10 and 11 , respectively. 


\section{DESCRIPTION OF METROLOGY ROBOT}

The metrology robot (Fig. 2-1) consists of a rotary table that positions a hexagonal core component in a vertical configuration and a twofinger replaceable probe (Fig. 2-2) that can move in an $x, y$, and $z$ Cartesian coordinate system (Fig. 2-3). The drive systems are powered by four programmable stepping motors. Each full step of the motors allows $0.025 \mathrm{~mm}$ $(0.001 \mathrm{in.})$ movement in the $x$ and $y$ directions, $0.032 \mathrm{~m}(0.00125 \mathrm{in}$. movement in the $z$ direction, and $0.03 \mathrm{deg}$ of rotation. The stepping motors are coupled with free-wheeling dc motors, which serve as auxiliary drive systems. The motor drives are modularized for quick replacement and maintenance. The coordinates of the probe are predetermined by three drives including rotation, with the fourth system driving the probe into the test object. The probe contains a displacement system to allow activation of two redundant microswitch systems.

The coordinates of the probe table are determined by a magnetic encoder system (Sony Magnescales), with rotary potentiometers as a redundant backup system. The displacement of the probe itself has two Cartesian measurement systems, i.e., linear potentiometers and linear variable differential tiransformers (LVDTS). The position of the rotary table is measured by a dual resolver system.

Data are recorded by a microprocessor controlled data logger (Accurex Autodata 9) with paper printout and magnetic tape deck. For automated operation and on-line evaluation, an LSI 11 minicomputer system (Nuclear Data ND6620) is used. The control and data acquisition units are shown in Fig - 2-4. 
The robot is instrumented with ten resistivity thermometers (RTDs) for temperature monitoring. System heatup occurs from decay heat of the irradiated fuel elements and the heat generated by the lighting required for visual inspections. Radiation- and temperature-resistant components are used as much as practicable.

Three remotely controlled black and white television camera systems for performing visual inspections are mounted on the robot. A color camera system located some distance from the robot is also used for performing visual inspections.

The metrology robot is operated in a fully automated closed-loop mode. This includes computer verification of proper movement and corrective actions with minimum or no operator interface. Intrinsic search routines are available to account for irradiation-induced shrinkage and bow of the graphite core components. Comparison of redundant measurement devices, as well as on-line data reduction, is done by the computer. This allows the system to automatically overcome potential malfunctions, such as motor stalling or missing an intended hole or surface. System redundancy is used to maximize data output and minimize downtime. 


\section{DESCRIPTION OF METROLOGICAL AND VISUAL INSPECTIONS}

A metrological inspection consists of two calibration and five test modules:

1. Calibration Module $I$ is conducted on the calibration cube to characterize probe deflection and robot precision and accuracy.

2. Calibration Module II is conducted on the rotary table for table orientation.

3. Test Module I consists of chord measurements at the top of the element to determine the distance across the flats [radial strain (see Fig. 3-1)].

4. Test Module II is an inspection of the six vertical block surfaces. Each surface is mapped via measurements at up to 55 points to determine the axial bow distribution (see Fig. 3-2).

5. Test Module III is an inspection of the top surface of the block at up to 54 locations to determine length changes (axial strain) and radial bow distribution (see Fig. 3-3).

6. Test Module IV measures the diameters and distances between up to 40 coolant holes at the top surface [incremental radial strain (see Fig . 3-4)] .

7. Test Module $\mathrm{V}$ measures changes in axial length (incremental axial strain) from fiducial holes drilled into each of the six corners of special surveillance and test elements (see Fig. 3-5). 
The time required for a metrological inspection of a full-size fuel element depends on the thoroughness of the inspection. The full-length inspection of a surveillance element includes 604 measurements on the block and requires $\sim 4-1 / 2 \mathrm{~h}$. The abbreviated inspection generally employed for nonsurveillance elements includes 370 measurements and requires $\sim 3 \mathrm{~h}$.

Visual inspections, which are performed concurrently with the metrological inspections, are done with four remotely controlled television camera systems and recorded on videotape in black and white or in color. A11 six sides and the top and bottom surfaces of the block are inspected. All surfaces of the block are also photographed as part of the visual inspection. 


\section{ROBOT PERFORMANCE}

The robot and its control and peripheral hardware performed extremely well over the 27 days of nearly continuous operation at FSV. Robot components were exposed to doses of up to $3 \times 10^{6} \mathrm{R}$ and temperatures close to $60^{\circ} \mathrm{C}$ without any observable detrimental effects. The few equipment failures that did occur are summarized in Table 4-1. None of these failures affected the robot's availability for the task, which was $100 \%$. The failure of the video recorder did, however, prohibit videotaping of the final 12 visual inspections. The doses and maximum temperatures experienced by selected robot components are given in Table 4-2. The doses are based on readings taken by FSV Health Physics. The detector failed after the seventh element. The dose rate measurements taken in the HSF are given in Table 4-3. The measurements at $1 \mathrm{~m}$ are correlated with fast neutron fluences calculated for the elements in Fig. 4-1. An average dose rate of $430 \mathrm{R} / \mathrm{h}$ for all 49 inspected fuel elements was approximated based on this correlation and the average fast neutron fluence for the elements. The reflector blocks were not included in the above calculation since their contribution to total doses was assumed to be negligible. Dose rates for the robot's components were calculated from the average dose rate at $1 \mathrm{~m}$ and the data given in Fig. 4-2 (Ref. 2). The relationship between dose rate and distance from a spent fuel block given in this figure is corroborated by the three measurements for element 1 .

The total time of irradiated fuel element residence on the robot turntable was $305 \mathrm{~h}$. (The residence time for the two reflector elements was about $20 \mathrm{~h}$.) In most cases, the temperatures reported in Table 4-2 are estimates, since the majority of the components were not monitored with RTDs. For these components, either the peak temperature recorded by the nearest RTD or the peak HSF air temperature is reported, depending on which 
was more representative. Heatup of components can be attributed primarily to the HSF lighting, rather than the spent fuel elements. This conclusion is based on the thermal response of the probe head RTD during heatup tests* and inspections of irradiated fuel elements (Table 4-4). The relatively low thermal response of the probe head RTD to spent fuel elements when the HSF air temperature was near $50^{\circ} \mathrm{C}$ and comparison of the RTD response during heatup tests and spent fuel element inspections point to fuel block surface temperatures in the vicinity of $50^{\circ}$ to $70^{\circ} \mathrm{C}$.

After undergoing preliminary decontamination at FSV, the robot was shipped back to San Diego. Final decontamination was performed at the GA hot cell and the robot was returned to the laboratory. Accessible areas of the robot have been cleaned to $<25 \mathrm{~d} / \mathrm{m}$ beta/100 $\mathrm{cm}^{2}$, a level permitting hands-on maintenance.

*Heatup tests were performed at element surface temperatures of $50^{\circ}$, $100^{\circ}, 150^{\circ}, 200^{\circ}$, and $300^{\circ} \mathrm{C}$, using a heatable dummy fuel block. 


\section{RESULTS OF METROLOGICAL INSPECTIONS}

\subsection{MEASURED STRAIN AND BOW}

Results of the metrological inspections of the 51 fuel and reflector elements from FSV core segment 1 are presented in Tables 5-1 and 5-2. Axial strains are element averages determined from element length measurements. Radial strains are average strains at the tops of the elements, as determined from across-flats measurements.* Preirradiation measurements were performed by GA (Ref. 1) and the Great Lakes Carbon Company (CORDAX machine measurements). The calculations employed to obtain strain and bow from preirradiation data and postirradiation metrology robot measurements are described in Ref. 3. Fast neutron fluences and temperatures given in Tables 5-1 and 5-2 were obtained from SURVEY (Ref. 4) code calculations based on the GAUGE (Ref. 5) code depletion analysis of FSV cycle 1, as operated. Time- and volumeaveraged graphite temperatures for the examined elements range from $-400^{\circ} \mathrm{C}$ to $750^{\circ} \mathrm{C}$. Element average fast neutron fluences range from $0.3 \times 10^{25} \mathrm{n} / \mathrm{m}^{2}$ to $1.0 \times 10^{25} \mathrm{n} / \mathrm{m}^{2}$ (E $>29 \mathrm{fJ}$ ) $\mathrm{HTGR}$. Based on the results of thermal and nuclear design verification studies that were performed with data from the Peach Bottom HTGR (Ref. 6), the uncertainty in the fast neutron fluence is assumed to be $\pm 10 \%(1 \sigma)$ and the uncertainty in the temperature is assumed to result from the $\pm 10 \%(1 \sigma)$ uncertainty in power. As such, the temperature uncertainty can be approximated by $10 \%$ of the difference between the local temperature and the gas inlet temperature $\left(330^{\circ} \mathrm{C}\right.$, time averaged). It should be pointed out that the doses received by the segment 1 elements, having been irradiated for

\footnotetext{
*Wobbling of the turntable (see Section 6) prevented radial strains at other axial positions along the elements from being computed from side-face measurements as had been planned. Measurements of coolant hole diameter and distance between coolant holes are too inaccurate to be used to determine radial strains in the segment 1 elements, because of the very small dimensional changes involved.
} 
only one cycle, are significantly less than the lifetime dose which would be received by most fuel elements in an HTGR. Also, since the FSV reactor operated at much less than full power during cycle 1 , the elements experienced lower temperatures than would generally be experienced by HTGR fuel elements except those in the top layers of the core. At these low temperatures and fluences, the strains are relatively small. Figures 5-1 and 5-2 are provided to give the reader some perspective as to how the segment 1 strain data relate to the range of potential strains in HTGR fuel elements.*

The axial and radial dimensions of nearly all of the 49 examined fuel elements were observed to have decreased as a result of irradiation. A few of the elements expanded slightly in the radial direction. The maximum element average axial and radial shrinkages measured for segment 1 fuel elements were $1.85 \mathrm{~mm}(0.073 \mathrm{in.)}$ and $0.79 \mathrm{~mm}(0.031 \mathrm{in.})$, respectively. The maximum expansion was $0.10 \mathrm{~mm}(0.004 \mathrm{in.})$. The maximum observed bow was $0.30 \mathrm{~mm}(0.012 \mathrm{in.})$. Both of the examined reflector elements underwent very little dimensional change. Comparisons of axial strains determined from total length changes and from changes in the distances between fiducial holes (Table 5-3) indicate that the axial shrinkage was uniform over the length of the elements.

One of the objectives of the FSV surveillance program is to inspect one complete core region from each reload segment. For segment 1, region 17 was inspected. Axial strain and bow distributions measured for region 17 elements are shown in Fig. 5-3. Thermal and nuclear calculations for region 17 indicate that temperatures and neutron fluxes increased gradually from one side of the region to the other due to the presence of a partially inserted control rod in region 34. The axial strain distribution in region 17 follows the same pattern. The bow in the elements corresponds to the

\footnotetext{
* Some liberty has been taken in showing the irradiation strain in Figs. 5-1 and 5-2. Although the measured strain, which is the total strain, is not directly comparable with irradiation strain, the irradiation strain is approximately equal to the total strain in an irradiated fuel element measured at room temperature, as is later discussed.
} 
observed axial strains. Generally speaking, faces A and D, B and E, and C and $F$ for a given element are bowed about the same amount in opposite directions. The sides having the lower (more positive) axial strains are convex and the opposite sides are concave.

Comparisons of robot measurements with measurements for surveillance element S/N 1-0743, performed with conventional hot cel1 measuring techniques, and with $Q C$ measurements for calibration element S/N 8-0182 (Section 6) have shown the accuracy of the metrology robot to be $\pm 0.18 \mathrm{~mm}(0.007 \mathrm{in.})$ $1 \sigma$, or better, for all measurements on these two elements. During each inspection at FSV, repeated measurements were made on a precisely machined 25.4-mm (1.000-in.) cube mounted on the turntable platform of the robot, to check the precision and accuracy of robot measurements. Standard deviations for these measurements are given in Table 5-3. These data confirm the quality of robot measurements for all of the examined elements.

\subsection{COMPARISONS OF MEASURED AND CALCULATED STRAINS AND BOW}

Strain and bow predictions obtained using the SURVEY/STRESS (Ref . 7) code are presented along with the corresponding measurements in Tables 5-1 and 5-2. SURVEY/STRESS calculates stresses, strains, and deformations in an LHTGR fuel block based on viscoelastic beam theory. It is one of three computer codes currently employed by GA to calculate stresses in LHTGR fuel blocks. It is the simplest and most efficient of the three and is used to survey the entire core to identify potentially critical elements. Once these elements are identified, they are subjected to more refined analyses using the GBEAM (Ref. 8) and SAFIRE (Ref. 9) codes. Since SURVEY/STRESS is used to calculate all important physical effects and structural interactions, the results obtained from this code should correlate reasonably well with results from the more refined analyses. 
Differences between calculated and measured strains for the segment 1 elements are plotted versus fast neutron fluence in Figs. 5-4 and 5-5. Also shown in each figure is the approximate uncertainty ${ }^{*}$ in the differences. The results of these comparisons are itemized below.

1. Axial Strain

a. Differences between measured and calculated strains are less than 0.0045 in./in. In most cases, the differences are less than the progressed uncertainty $(1 \sigma)$.

b. As a group, the axial strains in elements having timeaveraged irradiation temperatures less than about $550^{\circ} \mathrm{C}$ are significantly (at the $90 \%$ confidence level) overpredicted.

c. The agreement between measured and calculated strains varies significant1y with temperature, indicating that the variation in strain with temperature is overpredicted at low fluence.

d. For a given range of irradiation temperatures, the agreement between measured and calculated strains does not vary significantly with fast neutron fluence, indicating that the variation in strain with fluence is well predicted.

2. Radial Strain

a. Differences between measured and calculated strains are less than $0.002 \mathrm{~mm} / \mathrm{mm}$. This is less than the uncertainty $(1 \sigma)$. Statistical tests show that the differences as a group can

\footnotetext{
* The uncertainty in the measured strain is negligible compared to the uncertainty in the calculated strain. The uncertainties in calculated strains were approximated using Eq. 5-2 .
} 
also be accounted for at 0.05 significance level by the progressed uncertainty.

b. The agreement between measured and calculated strains varies mildly with both fast neutron fluence and temperature, but in general, the variation in strain with both of these parameters is well predicted.

A plot of calculated bow versus measured bow is given in Fig. 5-6. It is evident that there is little correlation (correlation coefficient $\approx 0.15$ ) between measured and calculated bow. This result is not surprising, since it has already been observed (Fig. 5-4) that the variation in axial strain with temperature is overpredicted.

At room temperature, the total strain in an irradiated fuel element is given by

$$
\left(\varepsilon_{\text {tot }}\right)_{\mathrm{RT}}=\varepsilon_{\mathrm{E}}+\varepsilon_{\mathrm{CR}}+\varepsilon_{\mathrm{I}} \text {, }
$$

where $\varepsilon_{E}=$ the elastic strain.

$\varepsilon_{\mathrm{CR}}=$ the creep strain.

$\varepsilon_{I}=$ the irradiation strain.

Based on the stresses calculated by SURVEY/STRESS, elastic and creep strains in the segment 1 elements are relatively sma11. Consequently, at room temperature, the total strain should be approximately equal to the irradiation strain. This was verified via a comparison of calculated irradiation strains with total strains calculated by SURVEY/STRESS for shutdown at end-of-1ife.*

\footnotetext{
* The thermal strain at the $350^{\circ} \mathrm{F}$ shutdown temperature was subtracted from the total strain.
} 
Irradiation strains are calculated by SURVEY/STRESS from a polynomial expression in two independent variables, temperature and fast neutron fluence. The general polynomial form presently used is

$$
\begin{aligned}
\varepsilon_{I} & =\left(C_{1}+C_{2} T+C_{3} T^{2}+C_{4} T^{3}+C_{5} T^{4}\right) \phi \\
& +\left(C_{6}+C_{7} T+C_{8} T^{2}+C_{9} T^{3}+C_{10} T^{4}\right) \phi^{2} \\
& +\left(C_{11}+C_{12} T+C_{13} T^{2}+C_{14} T^{3}+C_{15} T^{4}\right) \phi^{3}
\end{aligned}
$$

The coefficients of the polynomial are found by applying the FUNFIT (Ref. 10) code to correlate a large quantity of data obtained from essentially isothermal irradiations of graphite samples. Since the irradiation strain is not linear with temperature and the temperature history for an element in a commercial reactor will never be isothermal, the irradiation strain cannot be obtained merely by plugging the current temperature and fast fluence into the polynomial. Nonisothermal irradiations are currently handled by an incremental procedure known as the "constant dose shifting rule." In a given time step, the incremental irradiation strain is the difference along an isothermal path between the strain at the end-of-step dose and the strain at the start-of-step dose. When the temperature changes, a shift is made from one isothermal path to another. The irradiation strain is obtained by summing the incremental irradiation strains.

If the total strain at room temperature is approximately equal to the irradiation strain, the uncertainty in the total strain is approximated by the uncertainty in the irradiation strain. This uncertainty is given by the equation

$$
\mathrm{S}_{\varepsilon_{\mathrm{I}}}=\left[\left(\mathrm{S}_{\mathrm{T}} \frac{\partial \varepsilon_{\mathrm{I}}}{\partial \mathrm{T}}\right)^{2}+\left(\mathrm{S}_{\phi} \frac{\partial \varepsilon_{\mathrm{I}}}{\partial \phi}\right)^{2}+\mathrm{S}_{\mathrm{Fit}}^{2}\right]^{1 / 2},
$$


where

$$
\begin{aligned}
S_{\mathrm{T}}= & \text { the uncertainty in the temperature. } \\
\mathrm{S}_{\phi}= & \text { the uncertainty in the fast neutron fluence. } \\
\mathrm{S}_{\mathrm{Fit}}= & \text { the standard deviation of the data about the design } \\
& \text { surface }\left(0.3 \times 10^{-2} \mathrm{~mm} / \mathrm{mm} \text { for axial strain and } 0.375 \mathrm{x}\right. \\
& 10^{-2} \mathrm{~mm} / \mathrm{mm} \text { for radial strain). }
\end{aligned}
$$

$\begin{aligned} \frac{\partial \varepsilon}{\partial T} \text { and } \frac{\partial \varepsilon}{\partial \phi}= & \text { the partial derivatives of the polynomial with respect } \\ & \text { to temperature and fluence. }\end{aligned}$

The uncertainties shown in Figs. 5-4 and 5-5 were obtained using the above equation.

Since the calculated strain at room temperature is almost entirely irradiation strain, the observed discrepancies between measured and calculated axial strains and bow can reasonably be attributed to problems in predicting the irradiation strain. Measured axial strains are compared with the design curves for dimensional change of H-327 graphite at low temperatures and fluences in Fig. 5-7.*

Two conclusions are apparent:

1. Measured axial strains in elements with time- and volume-averaged irradiation temperatures less than $550^{\circ} \mathrm{C}$ are systematically lower than expected, based on the design curves.

2. Axial strains at temperatures below $750^{\circ} \mathrm{C}$ are less temperature-dependent than indicated by the design curves.

\footnotetext{
*The comparison is reasonably valid not only because the strain is almost entirely irradiation strain, but also because the variations in temperature and fast neutron fluence within the segment 1 elements were relatively small (see footnotes to Table 5-1). Consequently, the average strain for an element should be approximately equivalent to the strain determined from the design strain curves using the element-averaged fast neutron fluence and the element- and time-averaged irradiation temperature.
} 
It appears that the design curves do not accurately represent the axial irradiation strain at low temperatures and fluences, particularly at temperatures below $\sim 550^{\circ} \mathrm{C}$. Since there are little 1o'w-temperature, low-fluence strain data available for H-327 graphite, the polynomial that represents the design data is largely determined by the more abundant data at higher fluences and temperatures. The design curves at the low fluences and temperatures are probably mathematical artifacts of the polynomial, and may have no physical significance.

Because they are so small, the differences between measured and calculated strains and bow have no significant effect on the acceptability of the performance of the fuel elements. As to the accuracy of the SURVEY/ STRESS calculations, more in-pile data over a wider range of irradiation temperatures and fast neutron fluences are required before overall conclusions can be made. These data will be obtained from future inspections of FSV reload segments. The approximate ranges of fast neutron fluence over which graphite strain data will be obtained from the examinations of elements from each of the original FSV core reload segments are shown in Figs. 5-1 and 5-2. In general, the data obtained at the lower end of each fast fluence range will be for lower irradiation temperatures and the data obtained at the upper end will be for high irradiation temperatures. 


\section{VERIFICATION OF METROLOGY ROBOT MEASUREMENTS}

Comparisons of robot measurements with $Q C$ measurements on a calibration block ( $\mathrm{S} / \mathrm{N}$ 8-0182) and with measurements made in the GA hot cell on surveillance element S/N 1-0743* were performed to determine the accuracy of robot measurements. These comparisons are shown in Tables 6-1 through 6-13. If it is assumed that the $Q C$ measurements and the hot cel1 measurements are true values, the difference between one of these measurements and the corresponding robot measurement represents a metrology robot measurement error. The average difference for a given type of measurement represents a measurement bias. The variance in the differences defines the accuracy of the measurements, providing the measurements are corrected for the bias. Accuracies and biases for metrology robot measurements, as determined from these comparisons, are given in Table 6-14.

The accuracy of the metrology robot is observed to be \pm 0.18 tm $(0.007$ in.) $1 \sigma$, or better, for each type of robot measurement. Measurement biases were determined to be $0.05 \mathrm{~mm}(0.002 \mathrm{in.)}$, or less, for all robot measurements except length measurements. The bias (ACTUAL-ROBOT) in the length measurements is 0.18 to 0.28 ma $(0.007$ to $0.011 \mathrm{in.})$. The reason for this bias is not currently known, but will be identified and corrected prior to the inspection of FSV segment 2. All length measurements for segment 1 fuel elements were increased by $0.18 \mathrm{~mm}(0.007 \mathrm{in.})$ to account for this bias.**

\footnotetext{
${ }^{*}$ Surveillance element S/N 1-0743 was returned to GA for destructive examination following nondestructive examination in the hot service facility at FSV.

${ }^{\star *}$ Length measurements were increased by 0.18 mather than by the average of 0.18 and $0.28 \mathrm{~mm}$, because the comparison between robot and QC measurements on the unirradiated block is thought to provide the more accurate estimate of the bias.
} 
Comparisons of metrology robot data with the corresponding QC and hot ce11 postirradiation examination (PIE) measurements also revealed two mechanical defects in the robot. Errors in robot bow measurements determined from four such comparisons are shown in Table 6-15. These data clearly identify a position-dependent bias in robot bow measurements and are interpreted to indicate a slight bow in the robot structure. All bow measurements for FSV segment 1 elements were corrected for this bias.

The second mechanical defect, wobbling of the robot turntable, was deduced from comparisons of side-face displacement measurements. These comparisons are shown in Table 6-16. Unlike the bias in bow measurements, the face-dependent bias in the displacement measurements varies significantly from comparison to comparison. Consequently, no correction could be applied to the side-face displacement measurements for segment 1 elements. This precluded the calculation of radial strain at axial locations other than the top of the element. The turntable bearing has been upgraded to eliminate this problem. 


\section{VISUAL INSPECTION}

All of the inspected elements were in good condition. No cracks were observed on any of the element surfaces. With the exception of two large chips on chamfers (both noted during preirradiation visual inspection), all observed abnormalities were surface markings only. These markings had not etched the graphite to any harmful extent. The observed abnormalities are discussed below and photographs are provided as illustrations. The first three abnormalities discussed (stains, rub marks, and interface marks) were previously observed during the inspection of core region 35 and have been well documented in Ref. 11. The format used in that report to identify the locations of these abnormalities has been adopted for Tables 7-1 through 7-3. All markings appearing on each of the examined elements are photographically documented in Ref. 12 .

\subsection{STAINS}

Markings that can best be described as "stains" were observed on the side faces of many elements. These stains were often wavy, very dark, usually about $6 \mathrm{~mm}$ ( $0.25 \mathrm{in.}$ ) wide, and traversed the full length of the block in a free flowing manner. It is assumed that they resulted from water in the core that evaporated, leaving a surface residue behind. These stains were most often seen on face $E$ of the elements; less of ten on faces $A, D$, and $F$; and only rarely on faces $B$ and $C$. Photographs of one such stain are given in Figs. 7-1 through 7-4. The locations of all observed stains are identified in Table 7-1.

\subsection{RUB MARKS}

The presence of surface rub marks confirms that some relative motion occurs between adjacent elements within the core. These rub marks were 
generally vertical columns of short, horizontal and parallel markings. Each marking was $\sim 10 \mathrm{~mm}$ (0.375 in.) long and spaced $6 \mathrm{~mm}(0.25 \mathrm{in.})$ apart. The columns are located about $25 \mathrm{~mm}$ ( 1 in.) from both the right and left corners of the side faces. Faces A, C, D, and F of every element had these rub marks; they were occasionally observed on faces $B$ and $E$ as well. Rub marks were the most prevalent of all distinguishing characteristics, appearing on 34 of the 39 elements for which videotapes were made. A photograph of these rub marks is given in Fig. 7-5. The locations of all rub marks are identified in Table 7-2.

\subsection{INTERFACE MARKS}

Interface marks are dark or light colored bands, $45 \mathrm{~mm}$ (1-3/4 in.) wide, extending across the full width of the block. They were observed on all sides of control elements (column 1) and on face $E$ of most of the regular elements. The core configuration is such that face $E$ is always the surface of the regular elements that faces the control-rod elements. The 45-mm (1-3/4-in.)-wide band represents two chamfer widths of $22 \mathrm{~mm}$ (7/8 in.) each for two elements on top of each other. The control-rod column is offset vertically from the six surrounding columns by one-quarter of a block length, which coincides with the axial position observed for interface marks. It is likely that the interface marks resulted from columns that had leaned together for extended periods during operation. Over time, soot deposits or some other chemical process stained the areas above and below or between the chamfers of vertically adjacent elements and the side faces of elements in neighboring columns. A photograph of an interface mark is given in Fig. 7-6. The locations of all observed interface marks are given in Table 7-3.

\subsection{SOOT DEPOSITS}

Many of the elements had very dark stains along the left or right corners of the side faces, usually located near the top or bottom of the 
block or adjacent to an interface mark (Fig. 7-7). Some of the soot deposits appeared to begin where rub marks ended.

\subsection{SIDE FACE C SCRATCH OR STAIN}

On 21 of the elements, * side face $C$ had a straight, long vertical line down the middle of the face extending the full length of the element. Some markings had the appearance of stains while others looked like scratches. A few of these lines were very light, and, upon closer examination, appeared to be dashed lines. Several of the markings consisted of two closely spaced parallel lines rather than a single line.

Because of the straightness of the line and the fact that face $C$ is the only surface with this particular marking, this abnormality is believed to have resulted from element handling, probably caused by the fuel-handling machine, which has a constant element orientation. An example of this is shown in Figs. 7-8 through 7-11.

\subsection{FINGERPRINTS}

A few elements had what appeared to be fingerprints, usually at the bottom of the side face (Fig, 7-12). These undoubtedly resulted from preirradiation handling of the element.

\subsection{CHIPS OF CHAMFERS AND SCRAPED CORNERS}

Two elements had large chips on the chamfer, one at the top surface and one at the bottom (Fig. 7-13). Both had been noted during the preirradiation inspection of the elements. Several corners between adjacent side faces were scraped or in some way dulled, leaving a portion of the corner flat. These scraped corners were of ten shiny in appearance.

\footnotetext{
*Poor illumination during some of the side face inspections may have prevented detection on more elements.
} 


\subsection{TOP SURFACE DOWELS}

Many top surface inspections showed a dowel with a small chip on the flat top surface. Again, because of the consistency of this type of marking, it is believed to be a result of the fuel-handling machine interface.

A few dowels also had wear debris, which came to rest on the top of the dowels (Fig. 7-14). Apparent1y, material was shaved off dowel holes in the bottom of one element by dowel pins on the top of an element stacked below, and the shavings tended to accumulate on the upper dowel surface.

\subsection{TOP SURFACE CIRCLE AROUND FUEL-HANDLING HOLE}

Many of the elements had a dark concentric circle, approximately $150 \mathrm{~mm}$ (6 in.) in diam, surrounding the centrally located fuel-handling hole in the top surface (Fig. 7-15). This discoloration is also assumed to have resulted from the fuel-handling machine interface.

\subsection{PAINTED LETTERS AND NUMBERS ON TOP SURFACE}

Several elements were observed to have a letter $\mathrm{H}$ and numbers such as 101 and 111 painted on the top surfaces (Fig. 7-16). This agrees with preirradiation documentation, which states that the fuel assembly type and number were stenciled on the top surface. For most elements, the fuel assembly type was either $\mathrm{A}$ or $\mathrm{H}$ and the numbers were $101,102,113,114$, $125,131,168,169$, and 1976 . 


\section{ACKNOWLEDGMENTS}

The authors wish to acknowledge the following individuals for their contributions to the task reported in this document.

Preparation and Preirradiation Characterization of Surveillance

Elements :

W. W. Hudritsch, W. J. Scheffel, and O. M. Stansfield

Metrology Robot Development:

C. F. Wallroth, T. L. Smith, N. I. Marsh, J. P. Smith, and

R. Cicotte (Simpact Associates)

Metrological and Visual Examination of Core Components at FSV:

C. F. Wallroth, T. L. Smith, N. I. Marsh, J. P. Smith, G. L. Hein,

F. McCord, B. L. Norman, R. D. Phelps, and all employees of Public Services of Colorado (PSC) who participated.

Data Reduction:

F. McCord, L. I. Jameson, P. K. Koch, and R. H. Leary

Nuclear, Thermal, and Strain Calculations:

V. Malakhof, S. C. Bachelor, and W. Shen

Hot Cell Measurements:

H. O. Johnson and staff

QC Measurements:

L. E. King 


\section{REFERENCES}

1. Hudritsch, W. W., et al., "Preirradiation Characterization of Material for the Fort St. Vrain HTGR Core Surveillance Program," General Atomic Report GA-A12455, June 30, 1975.

2. Marsh, W., "Dose Rate Calculations for FSV Spent Fuel Block," General Atomic Company unpublished data.

3. Saurwein, J. J., "Specifications for Computer Code to Reduce Dimensional Data for FSV Fuel and Reflector Elements," General Atomic Company unpublished data, April 11, 1980.

4. Georghiou, D. L., "SURVEY, A Computer Code for the Thermal and Fuel Performance Analysis of High Temperature Gas-Cooled Reactors, Part I User's Manual," General Atomic Company unpublished data, November 1978.

5. Wagner, M. R., "GAUGE, A Two-Dimensional Few Group Neutron Diffusion-Depletion Program for a Uniform Triangular Mesh," Gulf Genera1 Atomic Report GA-8307, March 15, 1968.

6. Saurwein, J. J., and C. F. Wallroth, "Nuclear and Thermal Design Verification for the Peach Bottom High-Temperature Gas-Cooled Reactor," DOE Report GA-Al4726, General Atomic Company, September 1979.

7. Smith, P. D., "SURVEY/STRESS, A Model to Calculate Irradiation-Induced Stresses, Strains, and Deformations in an HTGR Fuel Block using Viscoelastic Beam Theory, Part-I - Theory," General Atomic Report GA-A13712, October 20, 1975.

8. Smith, P. D., and D. Georghiou, "GBEAM, A Computer Program to Calculate Irradiation-Induced Stresses, Strains, and Deformations in a Graphite Structure Using Viscoelastic Beam Theory," General Atomic Report GA-A13252, December, 1974.

9. Sevier, L., et al., "A Structural Analysis of FSV Initial Core Fuel Elements Using LHTGR Methods," General Atomic Company unpublished data, December 1977. 
10. Doering, D. A., "FUNFIT N-Space Function Fitting," General Atomic Report GAMD-8630, May 1, 1968.

11. Meyer, R.'J., "Fort St. Vrain In-Core Inspection, Region 35 and Region 13 Core Support Block," General Atomic Report GA-A15465, June 1979.

12. "Visual Examination of FSV Segment 1 - Inspections 1-51," General Atomic Company unpublished data, ( 5 notebooks of photographs). 


\section{TABLES}

1-1. Summary of FSV core segment 1 surveillance.

4-1. Failures in surveillance equipment.

4-2. Environmental conditions for selected robot components.

4-3. Gamma dose rate readings in FSV Hot Service Facility.

4-4. Thermal response of probe head during heatup tests and selected spent fuel element inspections.

5-1. Results of metrological inspections of core components from FSV segment 1 - axial strain and bow.

5-2. Results of metrological inspections of FSV segment 1 core components - radial strain.

5-3. Comparison of axial strains determined from distance between fiducial hole and element length measurements.

5-4. Standard deviations (precision) for robot measurements performed on calibration cube.

6-1. Comparison of robot and hot cell axial dimension measurements for surveillance element S/N 1-0743.

6-2. Comparison of robot and hot cell distance between coolant hole measurements for surveillance element S/N 1-0743. 
6-3. Comparison of robot and hot cell across-flats measurements for surveillance element S/N 1-0743.

6-4. Comparison of robot and hot cell length measurements for surveillance element S/N 1-0743.

6-5. Comparison of robot and hot cell coolant hole diameter measurements for surveillance element $\mathrm{S} / \mathrm{N}$ 1-0743.

6-6. Robot and hot cell bow measurements for surveillance element $\mathrm{S} / \mathrm{N}$ $1-0743$.

6-7. Comparison of robot and hot cell bow measurements for surveillance element S/N 1-0743.

6-8. Distance between fiducial hole measurements for calibration element S/N 8-0182.

6-9. Comparison of robot and QC distance between fiducial hole measurements for calibration element S/N 8-0182.

6-10. Across-flats measurements for calibration elements S/N 8-0182.

6-11. Comparison of robot and QC across-flats measurements for calibration element S/N 8-0182.

6-12. Length measurements for calibration element $\mathrm{S} / \mathrm{N}$ 8-0182.

6-13. Comparison of robot and QC length measurements for calibration element S/N 8-0182.

6-14. Accuracy of metrology robot measurements. 
6-15. Apparent bow in block resulting from bow in robot structure.

6-16. Displacement of side faces at top of block relative to side faces at bottom of block.

7-1. Locations of stains observed during surveillance of core segment 1 .

7-2. Locations of rub marks observed during surveillance of core segment 1 .

7-3. Locations of interface marks observed during surveillance of core segment 1 . 
TABLE $1-1$

SUMMARY OF FSV CORE SEGMENT 1 SURVEILLANCE

\begin{tabular}{|c|c|c|c|c|c|c|}
\hline Element & $\begin{array}{l}\text { Element } \\
\text { Serial No. }\end{array}$ & $\begin{array}{c}\text { Core } \\
\text { Location (a) }\end{array}$ & $\begin{array}{l}\text { Date } \\
(1979)\end{array}$ & $\begin{array}{l}\text { Time on } \\
\text { Robot (b) }\end{array}$ & $\begin{array}{l}\text { Number of } \\
\text { Inspections }\end{array}$ & $\begin{array}{l}\text { Inspection } \\
\text { Version }(c)\end{array}$ \\
\hline 1 & $01-0743$ & $17.04 \cdot F \cdot 06$ (d) & $7 / 6$ & $13: 52$ & 1 & $\mathbf{F}$ \\
\hline 2 & 01-1989 & $17.04 . F .09$ (d) & $7 / 6$ & $7: 55$ & 1 & $\mathbf{F}$ \\
\hline 3 & $02-2187$ & $17.01 . F .03(d)$ & $7 / 6,7 / 9$ & $14: 50$ & 3 & $\mathrm{~F}, \mathrm{~F}_{\mathrm{D}}, \mathrm{F}_{\mathrm{D}}$ \\
\hline 4 & $42-1004$ & $17.05 \cdot R \cdot 10^{(d)}$ & $7 / 10$ & $13: 28$ & 3 & $\mathrm{~F}, \mathrm{~F}, \mathrm{~F}_{\mathrm{p}}$ \\
\hline 5 & 42-1012 & $17.05 \cdot R .03$ (d) & $7 / 11$ & $6: 00$ & 1 & $\mathrm{~F}$ \\
\hline 6 & $01-2935$ & $17.05 . \mathrm{F} .06$ & $7 / 11$ & $8: 15$ & 2 & $\vec{F}, F_{D}$ \\
\hline 7 & $01-1253$ & $05.07 . \mathrm{F} .06$ (d) & $7 / 13-7 / 16$ & $71: 15$ & 4 & $F_{D}, F_{D}, F_{0}, F_{0}$ \\
\hline 8 & $01-0867$ & $05.07 . \mathrm{F} .09$ (d) & $7 / 16$ & $8: 35$ & 2 & $F_{D}, F_{D}=p=p$ \\
\hline 9 & $01-0681$ & $17.06 \cdot F .06$ & $7 / 17$ & $3: 00$ & 1 & \\
\hline 10 & $01-0204$ & $17.07 . F .06$ & $7 / 17$ & $2: 56$ & 1 & A \\
\hline 11 & $02-0286$ & $17.01 . F .05$ & $7 / 17$ & $2: 42$ & 1 & A \\
\hline 12 & $01-0049$ & $17.02 . \mathrm{F} .06$ & $7 / 18$ & $7: 30$ & 2 & $A, A$ \\
\hline 13 & $01-1624$ & $17.03 . F .06$ & $7 / 18$ & $4: 25$ & 1 & A \\
\hline 14 & $01-1714$ & $17.04 . F .08$ & $7 / 18$ & $3: 05$ & 1 & $A$ \\
\hline 15 & $01-2309$ & $17.04 . F .07$ & $7 / 18,7 / 19$ & $8: 50$ & 2 & $\mathrm{~F}, \mathrm{~A}$ \\
\hline 16 & $01-1346$ & $17.04 . F .05$ & $7 / 19$ & $3: 07$ & 1 & $\vec{A}$ \\
\hline 17 & $01-1035$ & $17.04 . F .04$ & $7 / 19$ & $3: 10$ & $i$ & A \\
\hline 18 & $01-2352$ & $17.05 . F .09$ & $7 / 19$ & $3: 55$ & 1 & A \\
\hline 19 & $01-1032$ & $17.06 . F .09$ & $7 / 19$ & $3: 10$ & 1 & A \\
\hline 20 & $01-1949$. & $17.07 . \mathrm{F} .09$ & $7 / 19,7 / 20$ & $8: 00$ & 2 & $F, F$ \\
\hline 21 & $01-0891$ & $17.02 . F .09$ & $7 / 20$ & $4: 25$ & $i$ & A \\
\hline 22 & $01-1054$ & $17.03 . F .09$ & $7 / 20$ & $2: 55$ & 1 & A \\
\hline 23 & $03-1711$ & $17.01 . F .08$ & $7 / 20$ & $2: 38$ & 1 & A \\
\hline 24 & $01-1861$ & $17.03 \cdot \mathrm{F} .08$ & $7 / 20,7 / 23$ & $3: 00$ & 2 & $A_{p}, A_{p}$ \\
\hline 25 & $01-2798$ & $17.05 . \mathrm{F} .08$ & $7 / 23$ & $2: 19$ & 1 & $A^{P}$ \\
\hline 26 & $01-2086$ & $17.06 \cdot F \cdot 08$ & $7 / 23$ & $6: 15$ & 2 & $A_{p}, A_{p}$ \\
\hline 27. & $01-1574$ & $17.07 . \mathrm{F} .08$ & $7 / 24$ & $2: 17$ & 1 & $A^{p}$ \\
\hline 28 & $02-1468$ & $17.01 . \mathrm{F} .07$ & $7 / 24$ & $2: 10$ & 1 & $A_{p}$ \\
\hline 29 & $01-2035$ & $17.02 . F .08$ & $7 / 24$ & $2: 30$ & 1 & $A^{p}$ \\
\hline 30 & $01-0733$ & $17.02 \cdot F .05$ & $7 / 24,7 / 25$ & $3: 35$ & 2 & $A_{p}, A_{p}$ \\
\hline 31 & $01-1658$ & $17.03 . F .05$ & $7 / 25$ & $7: 15$ & 3 & $A_{p}, A_{p}^{P}, A$ \\
\hline 32 & $01-0993$ & $17.05 . F .05$ & $7 / 25$ & $3: 05$ & 1 & $A^{p}$ \\
\hline 33 & $01-4381$ & $17.06 . F .05$ & $7 / 25$ & $2: 50$ & 2 & $A_{p}, A_{p}$ \\
\hline 34 & $01-0641$ & $17.07 . F .05$ & $7 / 25$ & $3: 22$ & 1 & $A^{p-p}$ \\
\hline 35 & $02-2548$ & $17.01 \cdot \mathrm{F} .04$ & $7 / 25,7 / 26$ & $1: 58$ & $i$ & A \\
\hline 36 & $02-2722$ & $17.01 . F .06$ & $7 / 26$ & $7: 23$ & 2 & $A, A$ \\
\hline 37 & $01-1136$ & $17.02 . \mathrm{F} .07$ & $7 / 26$ & $2: 54$ & 1 & A \\
\hline 38 & $01-1450$ & $17.03 . \mathrm{F} .07$ & $7 / 26$ & $5: 30$ & 2 & $A, A_{p}$ \\
\hline 39 & $01-2008$ & $17.05 \cdot \mathrm{F} .07$ & $7 / 26$ & $4: 16$ & $i$ & $\mathrm{~A}$ \\
\hline 40 & $01-1923$ & 17.06 .F. 07 & $7 / 27$ & $7: 35$ & 2 & $A, A$ \\
\hline 41 & $01-1446$ & $17.07 . F .07$ & $7 / 27$ & $3: 15$ & $i$ & $A$ \\
\hline 42 & $04-1050$ & 17.07 .F. 04 & $7 / 27$ & $3: 05$ & 1 & A \\
\hline 43 & $01-0003$ & $17.02 \cdot \mathrm{F} .04$ & $7 / 27$ & $3: 00$ & $i$ & A \\
\hline 44 & $01-0148$ & $17.03 . \mathrm{F} .04$ & $7 / 27$ & $4: 25$ & 1 & A \\
\hline 45 & $01-1215$ & $17.05 \cdot \mathrm{F} .04$ & $7 / 30$ & $7: 30$ & $i$ & A \\
\hline 46 & $01-1055$ & $17.06 . F .04$ & $7 / 30$ & $5: 10$ & $i$ & A \\
\hline 47 & $01-0424$ & $25.07 . F .06$ & $7 / 31$ & $2: 52$ & 1 & A \\
\hline 48 & $01-0990$ & $22.06 \cdot F \cdot 06$ & $7 / 31$ & $4: 15$ & $i$ & A \\
\hline 49 & $01-2928$ & $30.04 . \mathrm{F} .06$ & $7 / 31,8 / 1$ & $8: 45$ & 2 & $A, A$ \\
\hline 50 & $05-2089$ & $24.03 . \mathrm{F} .06$ & $8 / 1$ & $3: 00$ & 1 & A \\
\hline 51 & $01-1262$ & $27.02 . \mathrm{F} .06$ & $8 / 1$ & $3: 15$ & $i$ & A \\
\hline
\end{tabular}

(a) Core location 17.04 .F.06 indicates core region 17, column 4, and axial layer 6. "F" indicates a fuel block element; " $R$ " Indicates a reflector.

(b) Given in hours and minutes.

(c) $F=$ full-length inspection, $A=$ abbreviated inspection; the subscript $p$ Indicates the inspection was only partially completed.

(d) Survelllance element. 
TABLE 4-1

FAILURES IN SURVEILLANCE EQUIPMENT

\begin{tabular}{|c|c|c|}
\hline Component & Reason for Failure & Comment \\
\hline Sony magnescale & $\begin{array}{l}\text { Broken wire in robot } \\
\text { control cabinet }\end{array}$ & $\begin{array}{l}\text { Problem diagnosed and } \\
\text { corrected in } \\
\text { approximately } 24 \mathrm{~h}\end{array}$ \\
\hline TV camera & $\begin{array}{l}\text { Power supply in camera } \\
\text { head failed }\end{array}$ & $\begin{array}{l}\text { Could not be repaired } \\
\text { until removed from the } \\
\text { HSF after all inspections } \\
\text { completed }\end{array}$ \\
\hline Video recorder & $\begin{array}{l}\text { Random failure in control } \\
\text { circuit caused recorder } \\
\text { to jam in rewind mode }\end{array}$ & $\begin{array}{l}\text { Failure occurred after } \\
\text { completion of inspection } \\
\text { for } 39 \text { th element. } \\
\text { Inoperable for remainder } \\
\text { of inspections. }\end{array}$ \\
\hline Floodlights & Burned out & $\begin{array}{l}\text { Inability to turn lights } \\
\text { of resulted in failure } \\
\text { relatively early in life } \\
\text { of project }\end{array}$ \\
\hline $\begin{array}{l}\text { Geiger-Miiller counter } \\
\text { and CdTe crystal }\end{array}$ & Never properly implemented & $\begin{array}{l}\text { Not really a failure, } \\
\text { since they never were } \\
\text { operable }\end{array}$ \\
\hline $\begin{array}{l}2 \text { Stepping } \\
\text { motor }\end{array}$ & $\begin{array}{l}\text { Inleakage of cleaning } \\
\text { fluid during } \\
\text { decontamination }\end{array}$ & $\begin{array}{l}\text { No effect on surveil- } \\
\text { lance since failure } \\
\text { occurred after } \\
\text { completion of task }\end{array}$ \\
\hline
\end{tabular}


TABLE 4-2

ENVIRONMENTAL CONDITIONS FOR SELECTED ROBOT COMPONENTS

\begin{tabular}{l|c|c|c|c}
\hline \multicolumn{1}{c|}{ Component } & $\begin{array}{c}\text { Approximate } \\
\text { Average Distance } \\
\text { from Block } \\
(\mathrm{cm})\end{array}$ & $\begin{array}{c}\text { Dose (a) } \\
(\mathrm{R})\end{array}$ & $\begin{array}{c}\text { Approximate } \\
\text { Peak } \\
\text { Temperature } \\
\left({ }^{\circ} \mathrm{C}\right)\end{array}$ & $\begin{array}{c}\text { Maximum } \\
\text { Rated } \\
\text { Temperature } \\
\left({ }^{\circ} \mathrm{C}\right)\end{array}$ \\
\hline Nearest Sony magnescale & 30 & $7.1 \times 10^{5}$ & 57 & 40 \\
Nearest rotary potentiometer & 30 & $7.1 \times 10^{5}$ & 57 (b) & 125 \\
Nearest linear potentiometer & 8 & $2.0 \times 10^{6}$ & 53 (b) & 175 \\
Nearest LVT & 8 & $2.0 \times 10^{6}$ & 53 (b) & 149 \\
Motor relays & 46 & $4.3 \times 10^{5}$ & 50 (b) & 125 \\
Nearest motor & 30 & $7.1 \times 10^{5}$ & 50 (b) & 65 \\
Probe limit microswitches & 5 & $2.4 \times 10^{6}$ & 53 (b) & 260 \\
Table 1imit microswitches & 23 & $9.4 \times 10^{5}$ & 51 (b) & 538 \\
Resolver & 13 & $1.5 \times 10^{6}$ & 54 & 125 \\
Wiring & 10 & $1.7 \times 10^{6}$ & 53 (b) & 200 \\
Nearest RTD & 3 & $2.9 \times 10^{6}$ & 53 (b) & 500 \\
Nearest TV camera & 41 & $5.0 \times 10^{5}$ & $50^{(\mathrm{b})}$ & 50 \\
\hline
\end{tabular}

(a) Average dose rate of $430 \mathrm{R} / \mathrm{h}$ at $1 \mathrm{~m}$ assumed for all fuel elements. Total residence time for irradiated fuel blocks on robot was $305 \mathrm{~h}$. Dose rates at locations of components were calculated from the average dose rate at $1 \mathrm{~m}$ and the data given in Fig. 4-2.

(b)

No direct temperature reading available. Either temperature of nearest resistivity thermometer (RTD) air temperature has been given, depending on which seems most appropriate. 
TABLE 4-3

GAMMA DOSE RATE READINGS IN FSV HOT SERVICE FACILITY

\begin{tabular}{|c|c|c|c|c|}
\hline \multirow{2}{*}{$\begin{array}{l}\text { Element } \\
\text { Serial } \\
\text { Number }\end{array}$} & \multirow{2}{*}{$\begin{array}{c}\text { Core } \\
\text { Location }\end{array}$} & \multicolumn{2}{|c|}{$\begin{array}{l}\text { Measured } \\
\text { Dose Rate }\end{array}$} & \multirow[b]{2}{*}{ Date } \\
\hline & & $R / h$ & Distance & \\
\hline \multirow[t]{3}{*}{$01-0743$} & $17.04 \cdot F .06$ & 500 & $3 \mathrm{ft}$ & $7 / 6 / 79$ \\
\hline & & 225 & $6 \mathrm{ft}$ & \\
\hline & & 200 & $7.5 \mathrm{ft}$ & \\
\hline \multirow[t]{3}{*}{$01-1989$} & $17.04 . F .09$ & 300 & $3 \mathrm{ft}$ & $7 / 6 / 79$ \\
\hline & & 125 & $6 \mathrm{ft}$ & \\
\hline & & 90 & $7.5 \mathrm{ft}$ & \\
\hline \multirow[t]{3}{*}{$02-2187$} & $17.01 \cdot F .03$ & 350 & $3 \mathrm{ft}$ & $7 / 6 / 69$ \\
\hline & & 175 & $6 \mathrm{ft}$ & \\
\hline & & 100 & $7.5 \mathrm{ft}$ & \\
\hline $42-1004$ & $17.05 \cdot R \cdot 10$ & 4.5 & $1 \mathrm{ft}$ & $7 / 10 / 79$ \\
\hline $42-1012$ & $17.05 \cdot R .03$ & 4.5 & $1 \mathrm{ft}$ & $7 / 11 / 79$ \\
\hline $01-2935$ & $17.05 \cdot F .06$ & 500 & $3 \mathrm{ft}$ & $7 / 11 / 79$ \\
\hline \multirow[t]{3}{*}{$01-1253$} & $05.07 \cdot F \cdot 06$ & 700 & $3 \mathrm{ft}$ & $7 / 13 / 79$ \\
\hline & & 400 & $6 \mathrm{ft}$ & \\
\hline & & 200 & $9 \mathrm{ft}$ & \\
\hline
\end{tabular}


TABLE 4-4

THERMAL RESPONSE OF PROBE HEAD RTD DURING HEATUP TESTS AND SELECTED FUEL ELEMENT INSPECTIONS

\begin{tabular}{|c|c|c|c|c|c|}
\hline Test Type & $\begin{array}{c}\text { Element } \\
\text { Surface } \\
\text { Temperature } \\
\left({ }^{\circ} \mathrm{C}\right)\end{array}$ & $\begin{array}{l}\text { Fast } \\
\text { Neutron } \\
\text { Exposure } \\
\left(10^{25} \mathrm{n} / \mathrm{m}^{2}\right) \\
(\mathrm{E}>29 \mathrm{fJ})_{\text {HTGR }}\end{array}$ & $\begin{array}{c}\text { Probe Head } \\
\operatorname{RTD}(\mathrm{a}) \\
\left({ }^{\circ} \mathrm{C}\right)\end{array}$ & $\begin{array}{c}\text { HSF Air } \\
\text { Temperature }(b) \\
\left({ }^{\circ} \mathrm{C}\right)\end{array}$ & $\begin{array}{l}\text { Thermal } \\
\text { Response } \\
\text { (RTD-Air) } \\
\left({ }^{\circ} \mathrm{C}\right)\end{array}$ \\
\hline Heatup & 300 & -- & 77.4 & 42.2 & 35.2 \\
\hline Heatup & 150 & -- & 58.2 & 40.2 & 18.0 \\
\hline Heatup & 50 & -- & 46.4 & 38.3 & 7.9 \\
\hline $\begin{array}{l}\text { E1ement } \\
\text { inspection } 1\end{array}$ & - & 0.91 & 43.2 & 35.6 & 7.6 \\
\hline $\begin{array}{l}\text { Element } \\
\text { inspection } 2\end{array}$ & - & 0.30 & 41.7 & 39.4 & 2.3 \\
\hline $\begin{array}{l}\text { Element } \\
\text { inspection } 49\end{array}$ & - & 0.90 & 48.7 & 47.1 & 1.6 \\
\hline $\begin{array}{l}\text { Element } \\
\text { inspection } 51\end{array}$ & - & $0.95(c)$ & $50 \cdot 3$ & 46.8 & 3.5 \\
\hline
\end{tabular}

(a) Peak temperature recorded during inspection.

(b) HSF air temperature monitored by RTD mounted on camera 1 at a distance of approximately $2 \mathrm{~m}$ from the top of an element situated on the robot turntable.

(c) Peak fast neutron fluence calculated for the 51 inspected elements. 
TABLE 5-1

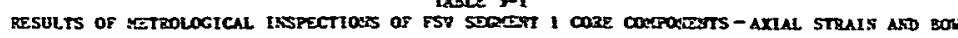

\begin{tabular}{|c|c|c|c|c|c|c|c|c|c|c|c|c|}
\hline \multirow[b]{2}{*}{$\begin{array}{l}\text { Element } \\
\text { Sertal } \\
\text { Number }\end{array}$} & \multirow[b]{2}{*}{$\begin{array}{c}\text { Core } \\
\text { Location }\end{array}$} & & \multicolumn{4}{|c|}{ Axdal Sctaifo(b) } & \multicolumn{3}{|c|}{ Bow } & \multicolumn{2}{|c|}{ Calculated Stresses (c) } \\
\hline & & $\frac{\text { Irradition }}{\substack{\text { Teeperature } \\
\text { ("c) }}}$ & 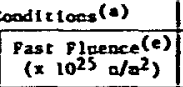 & $\frac{\text { Mess }}{\left(c_{z}\right)_{0}}$ & {$\left[\begin{array}{l}-10 \\
\text { (z) }\end{array}\right.$} & \begin{tabular}{|c|} 
Calc (f) \\
$\left(\varepsilon_{2}\right)_{c}$ \\
$(t)$
\end{tabular} & \begin{tabular}{c|} 
Difference \\
$\left.\left(c_{2}\right)_{c}-\left(c_{2}\right)_{b}\right)$ \\
\end{tabular} & $\begin{array}{l}\text { Mexsared } \\
\text { (m) }\end{array}$ & $\begin{array}{c}\text { Calc. (8) } \\
(-\infty)\end{array}$ & $\begin{array}{c}\text { Differeace } \\
\text { C - } \\
\text { (e) }\end{array}$ & $\begin{array}{l}\text { Yaximen } \\
\text { Stress } \\
\text { (MPa) }\end{array}$ & \begin{tabular}{|c|} 
Maxiaun \\
Seress - \\
Streagth Ratio
\end{tabular} \\
\hline $2-2187$ & $17.01 . F .03$ & 833 & 0.476 & -0.123 & 0.014 & -0.473 & -0.350 & 0.10 & 0.04 & -0.06 & 6.63 & 0.25 \\
\hline $1-\infty 003$ & 17.02 .7 .04 & $\$ 12$ & 0.470 & -0.102 & 0.016 & -0.525 & -0.423 & 0.10 & 0.16 & 0.06 & 5.96 & 0.22 \\
\hline $1-0148$ & 17.03 .7 .04 & 439 & 0.576 & -0.136 & 0.011 & -0.535 & -0.800 & 0.10 & 0.20 & 0.10 & 6.61 & 0.22 \\
\hline $1-1035$ & 17.04 .7 .04 & 484 & 0.613 & -0.125 & 0.017 & -0.552 & -0.366 & 0.13 & 0.21 & 0.08 & 6.67 & 0.24 \\
\hline $1-1215$ & 17.05 .5 .04 & 433 & 0.585 & -0.138 & 0.017 & -0.561 & -0.423 & 0.10 & 0.25 & 0.15 & 6.59 & 0.22 \\
\hline $1-1055$ & 17.06 .7 .04 & 419 & 0.519 & -0.119 & 0.014 & -0.541 & -0.422 & 0.08 & 0.21 & 0.19 & 6.45 & 0.24 \\
\hline $4-1050$ & 17.07 .8 .04 & 403 & 0.464 & -0.091 & 0.017 & -0.523 & -0.632 & 0.05 & 0.19 & 0.14 & 5.52 & 0.21 \\
\hline $2-2548$ & 17.01 .7 .04 & $\$ 20$ & 0.670 & $\mathrm{~m}(\mathrm{~b})$ & - & -0.357 & - & 0.15 & 0.11 & -0.04 & 6.59 & 0.25 \\
\hline $1-0733$ & $17.02 . \mathrm{F} .05$ & 485 & 0.678 & -0.17 & 0.014 & -0.448 & -0.271 & 0.13 & 0.33 & 0.20 & 6.07 & 0.22 \\
\hline $1-1658$ & 17.03 .8 .05 & 533 & 0.820 & -0.211 & 0.014 & -0.374 & -0.163 & 0.23 & 0.17 & -0.06 & 6.25 & 0.27 \\
\hline $1-1346$ & 17.04 .7 .05 & $5 s 1$ & 0.893 & -0.233 & 0.017 & -0.349 & $=0.116$ & 0.23 & 0.03 & -0.25 & 6.47 & 0.28 \\
\hline $1-0993$ & $17.05 . F .05$ & 528 & 0.852 & -0.232 & 0.016 & -0.393 & -0.151 & 0.23 & 0.23 & $0 . \infty$ & 6.40 & 0.27 \\
\hline $1-4381$ & 17.06 .7 .05 & 494 & 0.737 & -0.196 & 0.016 & -0.466 & -0.298 & 0.18 & 0.34 & 0.16 & 6.28 & 0.23 \\
\hline $1-0641$ & 17.07 .5 .05 & 467 & 0.641 & -0.154 & -0.011 & -0.478 & -0.324 & 0.05 & 0.41 & 0.36 & 5.76 & 0.21 \\
\hline $2-0286$ & 17.01 .7 .05 & 570 & 0.732 & -0.110 & 0.017 & -0.209 & -0.099 & 0.10 & 0.16 & 0.06 & 5.10 & 0.19 \\
\hline $1-\infty, 49$ & 17.02 .8 .06 & 543 & 0.737 & -0.159 & 0.011 & -0.289 & -0.130 & 0.18 & 0.39 & 0.20 & 5.32 & 0.20 \\
\hline $1-1624$ & 17.03 .7 .06 & 607 & 0.889 & -0.178 & 0.014 & -0.190 & -0.012 & 0.25 & 0.17 & -0.08 & 4.57 & 0.17 \\
\hline $1-0743$ & 17.04 .8 .06 & 632 & 0.972 & -0.182 & 0.014 & -0.158 & 0.024 & 0.30 & 0.05 & -0.25 & 4.54 & 0.17 \\
\hline $1-2935$ & 17.05 .7 .06 & 601 & 0.927 & -0.184 & 0.011 & -0.203 & -0.019 & 0.25 & 0.18 & -0.08 & 5.02 & 0.19 \\
\hline $1-0.581$ & 17.06 .9 .06 & 553 & 0.799 & $\mathbf{H A}$ & - & -0.271 & - & 0.18 & 0.33 & 0.15 & 5.18 & 0.19 \\
\hline $1-0204$ & 17.07 .8 .06 & 518 & 0.696 & si & - & -0.335 & - & 0.08 & 0.47 & 0.39 & 5.31 & 0.20 \\
\hline $2-2722$ & 17.01 .5 .06 & 609 & 0.611 & -0.065 & 0.017 & -0.125 & -0.060 & 0.05 & 0.13 & 0.08 & 2.97 & 0.11 \\
\hline $1-1136$ & 17.02 .7 .07 & 577 & 0.616 & -0.090 & 0.015 & -0.176 & $-0.02 s$ & 0.10 & 0.30 & 0.20 & 3.37 & 0.13 \\
\hline $1-1450$ & 17.03 .5 .07 & 650 & 0.740 & -0.136 & 0.014 & -0.093 & 0.38 & 0.18 & 0.12 & -0.06 & 2.68 & 0.10 \\
\hline $1-2309$ & .17 .04 .5 .07 & 682 & 0.811 & -0.120 & 0.016 & -0.077 & 0.043 & 0.20 & 0.04 & -0.16 & 1.92 & 0.07 \\
\hline $1-2008$ & 17.05 .7 .07 & 645 & 0.774 & -0.122 & 0.014 & -0.105 & 0.017 & 0.15 & 0.11 & -0.04 & 2.70 & 0.10 \\
\hline $1-1923$ & $17.06 . F .07$ & 587 & 0.665 & -0.095 & 0.014 & -0.166 & -0.071 . & 0.10 & 0.24 & 0.14 & 3.23 & 0.12 \\
\hline $1-1446$ & 17.07 .8 .07 & 548 & 0.580 & -0.098 & 0.011 & -0.217 & $-0.119^{\circ}$ & 0.05 & 0.27 & 0.22 & 3.43 & 0.13 \\
\hline $1-1468$ & 17.01 .5 .07 & 643 & 0.497 & -0.033 & 0.016 & -0.079 & -0.045 & 0.05 & 0.10 & 0.05 & 1.84 & 0.10 \\
\hline $1-2035$ & $17.02,7.08$ & 608 & 0.500 & -0.059 & 0.014 & -0.109 & -0.050 & 0.05 & 0.22 & 0.17 & 2.12 & 0.08 \\
\hline $1-1861$ & $17,03.7 .08$ & 690 & 0.598 & -0.005 & 0.017 & -0.056 & 0.001 & 0.08 & 0.07 & -0.01 & 1.47 & 0.06 \\
\hline $1-1718$ & 17.04 .7 .08 & 126 & 0.657 & -0.058 & 0.014 & -0.044 & 0.014 & 0.10 & 0.01 & -0.09 & $1 . \infty$ & 0.05 \\
\hline $1-2798$ & 17.05 .5 .08 & 683 & 0.627 & -0.061 & 0.011 & -0.059 & 0.002 & 0.08 & 0.07 & $-0.0 t$ & 1.90 & 0.08 \\
\hline $1=2086$ & 17.06 .5 .08 & 618 & 0.337 & -0.048 & 0.021 & -0.101 & -0.0053 & 0.05 & 0.17 & 0.12 & 1.94 & 0.08 \\
\hline $1-1574$ & $17.07 . F .08$ & 574 & 0.472 & -0.055 & 0.014 & -0.142 & -0.087 & 0.05 & 0.30 & 0.25 & 2.50 & 0.10 \\
\hline $3-1711$ & 17.01 .7 .08 & 658 & 0.324 & -0.008 & 0.017 & -0.050 & -0.042 & 0.03 & 0.06 & 0.03 & 1.63 & 0.12 \\
\hline $1-0891$ & 11.02 .8 .09 & 620 & 0.327 & -0.013 & 0.013 & -0.067 & -0.0054 & 0.03 & 0.16 & 0.11 & 2.06 & 0.10 \\
\hline $1-1058$ & 17.03 .7 .09 & 710 & 0.391 & -0.025 & 0.014 & -0.033 & -0.008 & 0.03 & 0.05 & 0.01 & 1.95 & 0.09 \\
\hline 1-1989 & 17.04 .7 .09 & 250 & 0.436 & -0.035 & 0.011 & -0.029 & -0.006 & 0.03 & $0 . \infty$ & -0.03 & 1.30 & 0.06 \\
\hline $1-2352$ & 17.05 .8 .09 & 704 & 0.416 & -0.030 & 0.021 & -0.036 & $-0.00 s$ & 0.03 & 0.08 & 0.01 & 2.50 & 0.12 \\
\hline $1-1032$ & 11.06 .5 .09 & 633 & 0.352 & -0.023 & 0.014 & -0.062 & -0.039 & 0.03 & 0.11 & 0.08 & 1.18 & 0.05 \\
\hline $1-1949$ & 17.07 .8 .09 & 286 & 0.309 & -0.026 & 0.014 & -0.00 & -0.063 & 0.05 & 0.19 & 0.14 & 2.08 & 0.08 \\
\hline $1-1253$ & 5.07 .8 .06 & $\$ 94$ & 0.815 & Es & - & -0.197 & - & 0.20 & 0.17 & -0.03 & 4.38 & 0.16 \\
\hline $1-0,24$ & 25.07 .7 .06 & 603 & 0.631 & -0.100 & 0.017 & -0.185 & -0.046 & 0.15 & 0.16 & 0.01 & 3.41 & 0.13 \\
\hline $1-0990$ & 22.06 .7 .06 & 661 & 0.640 & -0.081 & 0.017 & -0.008 & -0.013 & 0.13 & 0.37 & 0.24 & 3.88 & 0.16 \\
\hline $1-2928$ & 30.04 .5 .06 & 599 & 0.747 & -0.123 & 0.017 & -0.184 & -0.081 & 0.13 & 0.09 & -0.06 & 4.04 & 0.19 \\
\hline$s-2089$ & 24.03 .5 .06 & 556 & 0.501 & -0.073 & 0.016 & -0.193 & -0.120 & 0.10 & 0.44 & 0.34 & 3.85 & 0.21 \\
\hline $1-1262$ & 27.02 .5 .06 & 690 & 0.974 & -0.152 & 0.017 & -0.092 & 0.060 & 0.18 & 0.05 & -0.13 & 2.61 & 0.13 \\
\hline $1-0867$ & 05.07 .7 .09 & 687 & $x$ & -0.081 & 0.011 & $x$ & - & 0.03 & $\mathrm{sx}$ & - & $x$ & $\mathrm{sc}$ \\
\hline $42-1004$ & $17.05 \cdot R \cdot 10$ & $x^{(1)}$ & $s x$ & $0 . \cos$ & 0.027 & $s x$ & - & 0.03 & $x$ & - & $x$ & $\mathbf{N C}$ \\
\hline 42-1012 & 17.05 .8 .03 & $x$ & $x$ & $n$ & - & $x$ & - & $x$ & $x$ & - & $x$ & $x$ \\
\hline
\end{tabular}

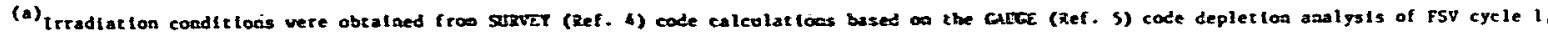
as operaced.

(b) Axial strains are eleont averages.

(c) Calculated atresses were obeal aed froo striver/stress.

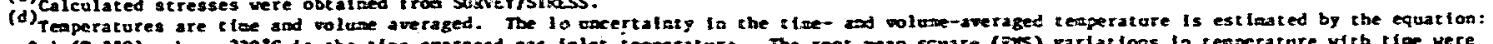

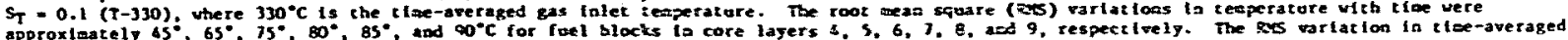

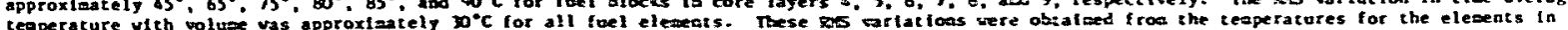

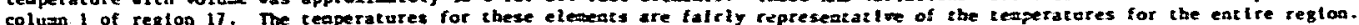

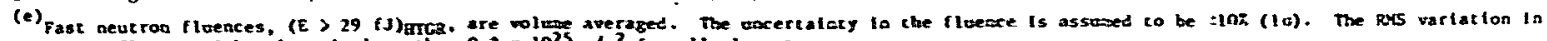
fast neutron fluence vith voluxe is less than $0.2 \times 10^{25} \mathrm{a} / \mathrm{a}^{2}$ for all electeats.

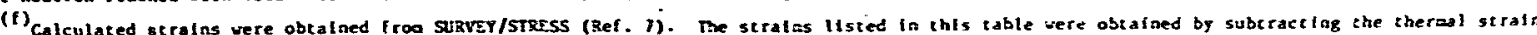

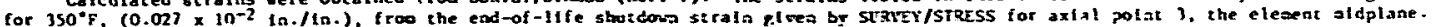

(8) Calculated bou vas obtalned troo suRrey/stress.

(h) $\mathrm{in}$ - Not avallable.

(1) Ne Not calculated. 
TABLE S-2
RESULTS OF METROLOGICAL INSPECTIONS OF FSV SEGMENT I CORE COMPONENTS - RADTAL STRAIN

\begin{tabular}{|c|c|c|c|c|c|c|c|}
\hline \multirow{3}{*}{$\begin{array}{l}\text { Elenent } \\
\text { Serial } \\
\text { Number }\end{array}$} & \multirow[b]{3}{*}{$\begin{array}{c}\text { Core } \\
\text { Location }\end{array}$} & \multirow{2}{*}{\multicolumn{2}{|c|}{ Irradiation Conditions(a) }} & \multicolumn{4}{|c|}{ Radial Strafn(b) } \\
\hline & & & & \multicolumn{2}{|c|}{ Measured } & \multirow{2}{*}{\begin{tabular}{|c|} 
Calculated $(e)$ \\
$\left(\varepsilon_{x}\right)_{c}$ \\
\end{tabular}} & \multirow{2}{*}{$\frac{\text { Difference }}{\left(\varepsilon_{x}\right)_{c}-\left(\varepsilon_{x}\right)_{M}}$} \\
\hline & & $\begin{array}{c}\text { Temperature }(\mathrm{c}) \\
\left({ }^{\circ} \mathrm{C}\right)\end{array}$ & $\begin{array}{l}\text { Fast Fluence }(d) \\
\left(\begin{array}{lll}x & 10^{25} \mathrm{n} / \mathrm{m}^{2}\end{array}\right)\end{array}$ & $\left(\varepsilon_{x}\right)_{y}$ & \pm 10 & & \\
\hline $2-2187$ & $17.01 . \mathrm{F} .03$ & 408 & 0.245 & -0.038 & 0.029 & 0.021 & 0.059 \\
\hline $1-0003$ & L7.02.F.04 & 394 & 0.207 & -0.003 & 0.025 & 0.019 & 0.022 \\
\hline $1-0148$ & $17.03 . F .04$ & 410 & 0.266 & -0.022 & 0.025 & 0.022 & 0.044 \\
\hline $1-1035$ & $17.04: F .04$ & 419 & 0.271 & -0.070 & 0.020 & 0.021 & 0.091 \\
\hline $1-1215$ & $17.05 . F .04$ & 410 & 0.259 & -0.063 & 0.071 & 0.021 & 0.084 \\
\hline $1-1055$ & $17.06 . F .04$ & 395 & 0.240 & -0.046 & 0.047 & 0.021 & 0.067 \\
\hline $4-1050$ & $17.07 . F .04$ & 387 & 0.196 & -0.020 & 0.025 & 0.018 & 0.038 \\
\hline $2-2548$ & 17.01 .8 .04 & 474 & 0.591 & -0.086 & 0.018 & 0.016 & 0.102 \\
\hline $1-0733$ & 17.02 .7 .05 & 448 & 0.593 & -0.091 & 0.015 & 0.026 & 0.117 \\
\hline $1-1658$ & $17.03 . F .05$ & 484 & 0.722 & -0.100 & 0.042 & 0.010 & 0.110 \\
\hline $1-1346$ & $17.04 . F .05$ & 496 & 0.775 & -0.142 & 0.021 & 0.003 & 0.145 \\
\hline $1-0993$ & 17.05 .7 .05 & 479 & 0.740 & -0.120 & 0.025 & 0.011 & 0.131 \\
\hline $1-4381$ & $17.06 . \mathrm{F} .05$ & 455 & 0.649 & -0.107 & 0.042 & 0.021 & 0.128 \\
\hline $1-0641$ & $17.07 . F .05$ & 434 & 0.560 & -0.070 & 0.011 & 0.030 & 0.100 \\
\hline $2-0286$ & 17.01 .F.05 & 546 & 0.717 & -0.071 & 0.032 & -0.019 & 0.052 \\
\hline $1-0049$ & $17.02 . \mathrm{F} .06$ & 516 & 0.725 & -0.150 & 0.030 & -0.005 & 0.145 \\
\hline $1-1624$ & $17.03 . P .06$ & 572 & 0.873 & -0.219 & 0.031 & -0.036 & 0.183 \\
\hline $1-0743$ & $17.04 . F .06$ & 594 & 0.956 & -0.130 & 0.026 & -0.052 & 0.078 \\
\hline $1-2935$ & $17.05 . F .06$ & 567 & 0.913 & -0.152 & 0.032 & -0.038 & 0.114 \\
\hline $1-0681$ & $17.06 . F .06$ & 525 & 0.786 & -0.162 & 0.029 & -0.013 & 0.149 \\
\hline $1-0204$ & 17.07 .F.06 & 494 & 0.685 & -0.129 & 0.024 & -0.005 & 0.134 \\
\hline $2-2722$ & $17.01 . P .06$ & 582 & 0.678 & -0.009 & 0.044 & -0.036 & -0.045 \\
\hline $1-1136$ & 17.02 .5 .07 & 533 & 0.692 & -0.096 & 0.027 & -0.021 & 0.075 \\
\hline $1-1450$ & $17.03 . F .07$ & 620 & 0.831 & -0.086 & 0.035 & -0.056 & 0.030 \\
\hline $1-2309$ & $17.04 . F .07$ & 649 & 0.912 & -0.103 & 0.042 & -0.075 & 0.028 \\
\hline $1-2008$ & 17.05 .7 .07 & 616 & 0.870 & -0.087 & 0.020 & -0.060 & 0.027 \\
\hline $1-1923$ & 17.06 .7 .07 & 563 & 0.746 & -0.075 & 0.019 & -0.030 & 0.045 \\
\hline $1-1446$ & $17.07 . F .07$ & 527 & 0.653 & -0.064 & 0.015 & -0.010 & 0.054 \\
\hline $1-1468$ & $17.01 . F .07$ & 627 & 0.562 & -0.015 & 0.025 & -0.043 & -0.028 \\
\hline $1-2035$ & $17.02 . \mathrm{F} .08$ & 593 & 0.564 & -0.030 & 0.014 & -0.029 & 0.001 \\
\hline $1-1861$ & $17.03 . F .08$ & 672 & 0.678 & -0.029 & 0.035 & -0.063 & -0.034 \\
\hline $1-1714$ & i7 .04.F.08 & 706 & 0.743 & -0.017 & 0.029 & -0.081 & -0.064 \\
\hline $1-2798$ & 17.05 .7 .08 & 666 & 0.709 & -0.036 & 0.021 & -0.065 & -0.029 \\
\hline $1-2086$ & $17.06 . F .08$ & 604 & 0.609 & -0.043 & 0.021 & -0.037 & 0.006 \\
\hline $1-1574$ & $17.07 . F .08$ & 562 & 0.533 & 0.015 & 0.033 & -0.018 & 0.033 \\
\hline $3-1711$ & $17.01 . F .08$ & 652 & 0.411 & 0.022 & 0.034 & -0.038 & 0.060 \\
\hline $1-0891$ & 17.02 .7 .09 & 616 & 0.420 & 0.012 & 0.030 & -0.028 & 0.040 \\
\hline $1-1054$ & $17.03 . \mathrm{F} .09$ & 701 & 0.500 & 0.010 & 0.032 & -0.055 & 0.045 \\
\hline $1-1989$. & $17.04 . P .09$ & 741 & 0.556 & 0.014 & 0.025 & -0.071 & 0.057 \\
\hline $1-2352$ & 17.05 .7 .09 & 696 & 0.531 & 0.009 & 0.023 & -0.058 & 0.049 \\
\hline $1-1032$ & 17.06 .7 .09 & 626 & 0.450 & 0.016 & 0.030 & -0.034 & 0.018 \\
\hline $1-1949$ & $17.07 . \mathrm{F} .09$ & 581 & 0.397 & 0.002 & 0.020 & -0.019 & 0.017 \\
\hline $1-1253$ & $05.07 . F .06$ & 557 & 0.818 & 0.121 & 0.039 & -0.029 & 0.092 \\
\hline $1-0424$ & $25.07 . F .06$ & 565 & 0.638 & 0.051 & 0.027 & -0.021 & 0.030 \\
\hline $1-0990$ & 22.06 .7 .06 & 612 & 0.633 & 0.029 & 0.024 & -0.040 & 0.011 \\
\hline $1-2928$ & 30.04 .7 .06 & 560 & 0.739 & 0.104 & 0.029 & -0.024 & 0.080 \\
\hline 5-2089 & $26.03 . p .06$ & 523 & 0.498 & 0.029 & 0.061 & -0.003 & 0.032 \\
\hline $1-1262$ & 27.02 .8 .06 & 642 & 0.971 & 0.100 & 0.024 & -0.078 & 0.022 \\
\hline $1-0867$ & $05.07 . F .09$ & 680 & 0.428 & 0.004 & 0.019 & $\mathrm{NC}(f)$ & -- \\
\hline 42-1004 & $17.05 \cdot \mathrm{R} \cdot 10$ & $\mathrm{NC}$ & NC & -0.013 & 0.017 & NC & -- \\
\hline 42-1012 & $17.05 . R .03$ & NC & NC & $\mathrm{NC}$ & -- & NC & - \\
\hline
\end{tabular}

(a) Irradiation conditions obtained from SURVEY (Ref. 4) code calculations based on the GAUGR (Ref. 5) code depletton analysis of FSV cycle 1 , as operated. Conditions are those near the top of the block.

(b) Radial stralns are element averages at the top of the block.

(c) Temperature are time and volume averaged.. The 10 uncertafnty in temperature is estimated by $S_{T}=0.1(T-330)$, where $330^{\circ} \mathrm{C}$ is the time-averaged gas inlet temperacure.

(d) Fast neutron fluences are volume averaged (actually averaged over the cross sectional area near the top of the element, as are temperatures). The uncertalnty in the fast fluence,

(E $>29 \mathrm{fJ})_{\mathrm{HTGR}}$ to assumed to be $\pm 10 \%(1 \sigma)$.

(e) The strains listed in this table were obtained by subtracting the thermal strain for $350^{\circ} \mathrm{P}$, $\left(0.056 \times 10^{-2} \mathrm{in} . / \mathrm{fn}.\right)$, frow the end-of-11fe shutdown stratn given by SURVEY/STRESS for axial

point 1 , the top of the elements.

(f) $\mathrm{NC}$ - Not calculated. 
TABLE $5-3$

COHPARISON OF AXIAL STRAINS DETERHIKED FRON DISTANCE BETHEEN FIDUCIAL HOLE AND ELEYENT LENGTH MEASUREYRTTS

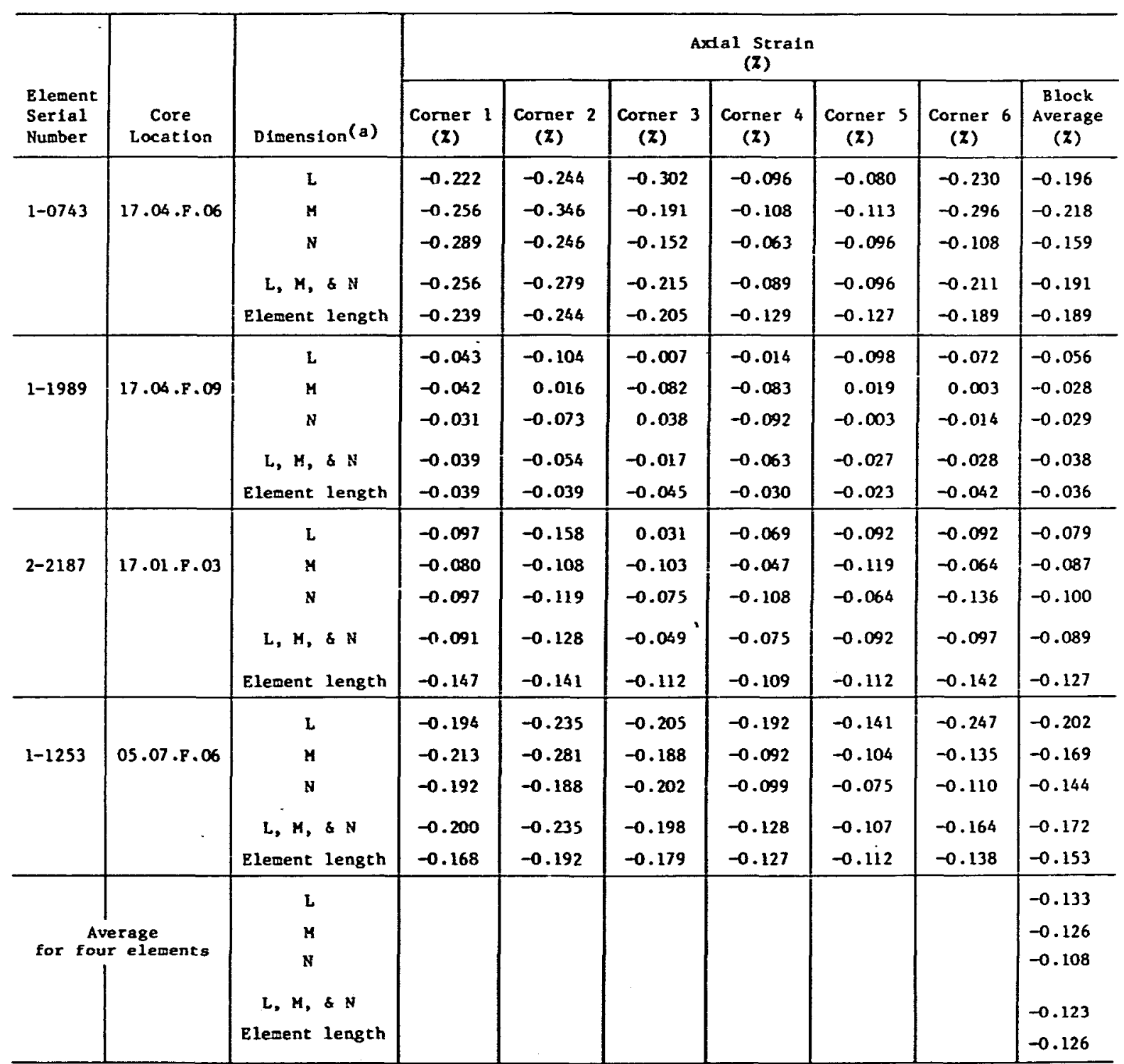

(a) See F18 $3-5$. 
TABLE $5-4$

STANDARD DEVIATIONS (PRECISION) FOR ROBOT MEASUREMENTS PERFORMED ON CALIBRATION CUBE

\begin{tabular}{|c|c|c|c|c|c|}
\hline \multirow[b]{2}{*}{$\begin{array}{l}\text { Inspection } \\
\text { Number }\end{array}$} & \multicolumn{5}{|c|}{ Precision $\pm 1 \sigma$} \\
\hline & $\begin{array}{c}\Delta x \text { Measured } \\
\text { with } Z \text { leg } \\
(\text { in.) }\end{array}$ & $\begin{array}{c}\Delta \mathrm{Y} \text { Measured } \\
\text { with } \mathrm{Z} \text { leg } \\
(\mathrm{In} .)\end{array}$ & $\begin{array}{l}\text { Z Coordinate } \\
\text { Measured with } \\
\text { Z leg } \\
\text { (in.) }\end{array}$ & $\begin{array}{l}\text { Y Coordinate } \\
\text { measured with } \\
\text { Y leg } \\
\text { (in.) }\end{array}$ & $\begin{array}{l}\text { Z Coordinate } \\
\text { measured with } \\
\text { Y leg } \\
\text { (in.) }\end{array}$ \\
\hline 1 & 0.001 & 0.001 & 0.002 & 0.001 & 0.001 \\
\hline 2 & 0.001 & 0.001 & 0.001 & 0.001 & 0.003 \\
\hline 3 & 0.001 & 0.001 & 0.002 & 0.000 & 0.003 \\
\hline 4 & 0.001 & 0.001 & 0.002 & 0.000 & 0.002 \\
\hline 5 & 0.001 & 0.000 & 0.002 & 0.000 & 0.001 \\
\hline 6 & 0.002 & 0.001 & 0.001 & 0.000 & 0.002 \\
\hline $7 a$ & 0.003 & 0.002 & 0.002 & 0.001 & 0.001 \\
\hline $7 \mathrm{~b}$ & 0.001 & 0.000 & 0.002 & 0.000 & 0.002 \\
\hline 8 & 0.001 & 0.001 & 0.001 & 0.001 & 0.002 \\
\hline 9 & 0.002 & 0.002 & 0.001 & 0.000 & 0.000 \\
\hline 10 & 0.001 & 0.002 & 0.001 & 0.001 & 0.000 \\
\hline 11 & 0.001 & 0.001 & 0.003 & 0.000 & 0.001 \\
\hline 12 & 0.002 & 0.002 & 0.001 & 0.001 & 0.004 \\
\hline 13 & 0.002 & 0.000 & 0.002 & 0.000 & 0.002 \\
\hline 14 & 0.002 & 0.001 & 0.002 & 0.001 & 0.002 \\
\hline 15 & 0.002 & 0.001 & 0.002 & 0.001 & 0.001 \\
\hline 16 & 0.001 & 0.000 & 0.003 & 0.001 & 0.002 \\
\hline 17 & 0.001 & 0.001 & 0.003 & 0.000 & 0.001 \\
\hline 18 & 0.002 & 0.001 & 0.004 & 0.001 & 0.003 \\
\hline 19 & 0.001 & 0.000 & 0.002 & 0.000 & 0.002 \\
\hline 20 & 0.001 & 0.001 & 0.002 & 0.000 & 0.002 \\
\hline 21 & 0.001 & 0.001 & 0.003 & 0.000 & 0.002 \\
\hline 22 & 0.002 & 0.001 & 0.002 & 0.001 & 0.002 \\
\hline 23 & 0.001 & 0.001 & 0.003 & 0.001 & 0.002 \\
\hline $24 a$ & 0.003 & 0.001 & 0.003 & 0.001 & 0.001 \\
\hline $24 \mathrm{~b}$ & 0.001 & 0.001 & 0.002 & 0.001 & 0.001 \\
\hline 25 & 0.001 & 0.001 & 0.001 & 0.001 & 0.002 \\
\hline $26 a$ & 0.000 & 0.000 & 0.002 & 0.001 & 0.001 \\
\hline $26 \mathrm{~b}$ & 0.000 & 0.000 & 0.004 & 0.000 & 0.001 \\
\hline 27 & 0.001 & 0.001 & 0.002 & 0.001 & 0.003 \\
\hline 28 & 0.001 & 0.001 & 0.002 & 0.001 & 0.002 \\
\hline 29 & 0.001 & 0.001 & 0.002 & 0.000 & 0.003 \\
\hline $30 a$ & 0.001 & 0.001 & 0.002 & 0.001 & 0.000 \\
\hline $30 \mathrm{~b}$ & 0.001 & 0.001 & 0.002 & 0.000 & 0.002 \\
\hline $31 a$ & 0.001 & 0.001 & 0.002 & 0.000 & 0.003 \\
\hline $31 \mathrm{~b}$ & 0.000 & 0.001 & 0.002 & 0.000 & 0.002 \\
\hline 32 & 0.001 & 0.003 & 0.002 & 0.001 & 0.002 \\
\hline $33 a$ & 0.001 & 0.000 & 0.002 & 0.001 & 0.02 \\
\hline $33 b$ & 0.001 & 0.000 & 0.002 & 0.000 & 0.003 \\
\hline 34 & 0.000 & 0.000 & 0.001 & 0.000 & 0.001 \\
\hline 35 & 0.001 & 0.001 & 0.002 & 0.001 & 0.002 \\
\hline $36 a$ & 0.001 & 0.001 & 0.003 & 0.000 & 0.002 \\
\hline 37 & 0.001 & 0.001 & 0.002 & 0.001 & 0.001 \\
\hline 38 & 0.001 & 0.001 & 0.002 & 0.001 & 0.001 \\
\hline 39 & 0.001 & 0.001 & 0.002 & 0.001 & 0.002 \\
\hline 40 & 0.001 & 0.001 & 0.002 & 0.000 & 0.002 \\
\hline 41 & 0.001 & 0.001 & 0.001 & 0.000 & 0.000 \\
\hline 42 & 0.001 & 0.003 & 0.003 & 0.001 & 0.002 \\
\hline 43 & 0.001 & 0.001 & 0.002 & 0.001 & 0.002 \\
\hline 44 & 0.000 & 0.001 & 0.003 & 0.001 & 0.002 \\
\hline 45 & 0.001 & 0.001 & 0.003 & 0.001 & 0.003 \\
\hline 46 & 0.001 & 0.000 & 0.002 & 0.001 & 0.003 \\
\hline 47 & 0.001 & 0.001 & 0.003 & 0.001 & 0.002 \\
\hline 48 & 0.002 & 0.001 & 0.003 & 0.000 & 0.001 \\
\hline 49 & 0.002 & 0.001 & 0.003 & 0.000 & 0.001 \\
\hline 50 & 0.002 & 0.001 & 0.002 & 0.001 & 0.001 \\
\hline 51 & 0.002 & 0.001 & 0.003 & 0.000 & 0.002 \\
\hline Av & 0.001 & 0.001 & 0.002 & 0.001 & 0.002 \\
\hline
\end{tabular}


TABLE 6-1

COMPARISON OF ROBOT AND HOT CELL AXIAL DIMENSION

MEASUREMENTS FOR SURVEILLANCE ELEMENT S/N 1-0743

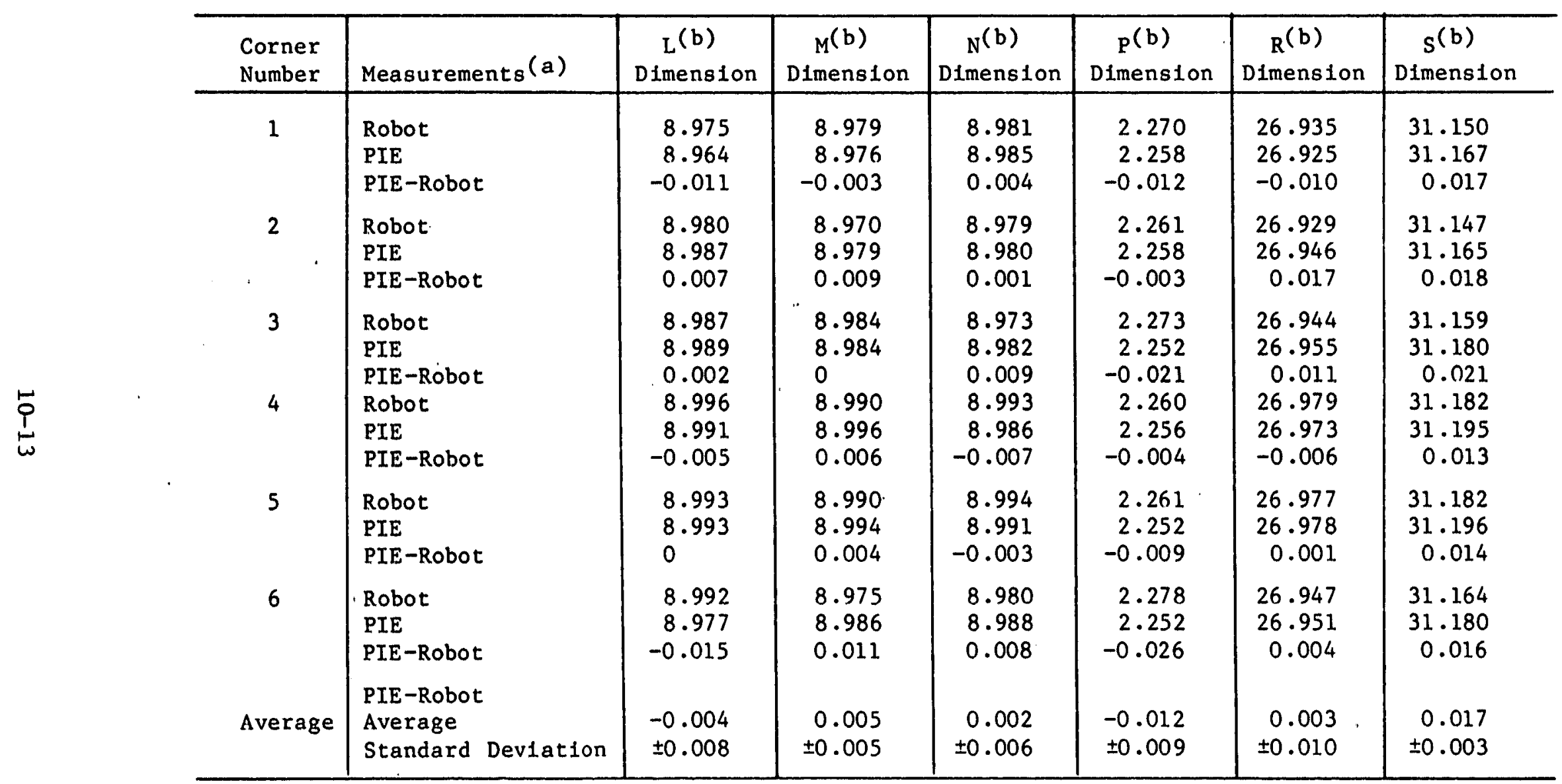

(a) All dimensions in inches.

(b) See Fig. 3-5. 
TABLE 6-2

COMPARISON OF ROBOT AND HOT CELL DISTANCE BETWEEN COOLANT HOLE MEASUREMENTS FOR

SURVEILLANCE ELEMENT S/N 1-0743

\begin{tabular}{|c|c|c|c|c|c|c|c|c|c|c|}
\hline \multirow[b]{2}{*}{ Measurement } & \multicolumn{10}{|c|}{$\begin{array}{c}\text { Distance Between Coolant Holes } \\
\text { (Inches) }\end{array}$} \\
\hline & $312-270$ & $270-219$ & 219-106 & $106-55$ & $55-13$ & $312-13$ & & & Mean & $\begin{array}{l}\text { Standard } \\
\text { Deviation }\end{array}$ \\
\hline $\begin{array}{l}\text { Robot } \\
\text { PIE } \\
\text { PIE-Robot }\end{array}$ & $\begin{array}{r}1.593 \\
1.591 \\
-0.002\end{array}$ & $\begin{array}{l}1.593 \\
1.598 \\
0.005\end{array}$ & $\begin{array}{r}3.814 \\
3.813 \\
-0.001\end{array}$ & $\begin{array}{l}1.593 \\
1.594 \\
0.001\end{array}$ & $\begin{array}{c}1.594 \\
1.594 \\
0\end{array}$ & $\begin{array}{l}12.688 \\
12.681 \\
0.007\end{array}$ & & & -0.001 & \pm 0.004 \\
\hline$\therefore$ & $319-295$ & $295-267$ & $267-235$ & $235-90$ & $90-58$ & $58-30$ & $30-6$ & $319-6$ & & \\
\hline \multirow[t]{2}{*}{$\begin{array}{l}\text { Robot } \\
\text { PIE } \\
\text { PIE-Robot }\end{array}$} & $\begin{array}{l}0.646 \\
0.655 \\
0.009\end{array}$ & $\begin{array}{r}0.665 \\
0.660 \\
-0.005\end{array}$ & $\begin{array}{l}0.639 \\
0.657 \\
0.018\end{array}$ & $\begin{array}{r}4.514 \\
4.498 \\
-0.016\end{array}$ & $\begin{array}{l}0.657 \\
0.660 \\
0.003\end{array}$ & $\begin{array}{l}0.648 \\
0.655 \\
0.006\end{array}$ & $\begin{array}{c}0.658 \\
0.658 \\
0\end{array}$ & $\begin{array}{l}12.181 \\
12.179 \\
-0.002\end{array}$ & 0.002 & \pm 0.010 \\
\hline & $303-264$ & $264-216$ & 216-109 & 109-61 & $61-22$ & $303-22$ & & & & \\
\hline \multirow[t]{2}{*}{$\begin{array}{l}\text { Robot } \\
\text { PIE } \\
\text { PIE-Robot }\end{array}$} & $\begin{array}{l}1.589 \\
1.595 \\
0.006\end{array}$ & $\begin{array}{l}1.590 \\
1.594 \\
0.004\end{array}$ & $\begin{array}{r}3.819 \\
3.814 \\
-0.005\end{array}$ & $\begin{array}{l}1.585 \\
1.593 \\
0.008\end{array}$ & $\begin{array}{l}1.586 \\
1.594 \\
0.008\end{array}$ & $\begin{array}{r}12.669 \\
12.681 \\
0.012\end{array}$ & & & 0.005 & \pm 0.006 \\
\hline & $170-167$ & $167-164$ & $164-161$ & $161-158$ & $158-155$ & $170-155$ & & & & \\
\hline \multirow[t]{2}{*}{$\begin{array}{l}\text { Robot } \\
\text { PIE } \\
\text { PIE-Robot }\end{array}$} & $\begin{array}{l}1.585 \\
1.593 \\
0.008\end{array}$ & $\begin{array}{l}1.589 \\
1.591 \\
0.002\end{array}$ & $\begin{array}{r}3.826 \\
3.817 \\
-0.009\end{array}$ & $\begin{array}{c}1.593 \\
1.593 \\
0\end{array}$ & $\begin{array}{l}1.590 \\
1.593 \\
0.003\end{array}$ & $\begin{array}{l}12.684 \\
12.678 \\
-0.006\end{array}$ & & & 0 & \pm 0.006 \\
\hline & $13-22$ & $22-170$ & $170-312$ & $312-303$ & $303-155$ & $155-13$ & & & & \\
\hline $\begin{array}{l}\text { Robot } \\
\text { PIE } \\
\text { PIE-Robot }\end{array}$ & $\begin{array}{l}6.028 \\
6.033 \\
0.005\end{array}$ & $\begin{array}{r}6.026 \\
6.022 \\
-0.004\end{array}$ & $\begin{array}{r}6.025 \\
6.024 \\
-0.001\end{array}$ & $\begin{array}{l}6.024 \\
6.028 \\
0.004\end{array}$ & $\begin{array}{l}6.027 \\
6.028 \\
0.001\end{array}$ & $\begin{array}{l}6.025 \\
6.031 \\
0.006\end{array}$ & . & . & & \\
\hline $\begin{array}{l}\text { Average } \\
\text { PIE-Robot }\end{array}$ & & . & & & & . & & & $\begin{array}{l}0.002 \\
0.002 \\
\end{array}$ & $\begin{array}{l} \pm 0.004 \\
\pm 0.007 \\
\end{array}$ \\
\hline
\end{tabular}


TABLE 6-3

COMPARISON OF ROBOT AND HOT CELL ACROSS-FLATS

MEASUREMENTS. FOR SURVEILLANCE ELEMENT S/N 1-0743

\begin{tabular}{|c|c|c|c|c|c|c|c|c|c|}
\hline Faces & Measurement $(a)$ & 1 & 2 & 3 & 4 & 5 & 6 & Average & $\begin{array}{l}\text { Standard } \\
\text { Deviation }\end{array}$ \\
\hline \multirow[t]{3}{*}{$A-D$} & Robot & 14.147 & 14.150 & 14.149 & 14.155 & 14.156 & 14.148 & & - \\
\hline & PIE & 14.151 & 14.151 & 14.154 & 14.154 & 14.156 & 14.157 & & \\
\hline & PIE-Robot & 0.004 & 0.001 & 0.005 & -0.001 & 0 & 0.009 & 0.003 & \pm 0.003 \\
\hline \multirow[t]{3}{*}{$B-E$} & Robot & 14.153 & 14.150 & 14.152 & 14.150 & 14.150 & 14.150 & & \\
\hline & PIE & 14.154 & 14.154 & 14.154 & $14 \cdot 1.54$ & 14.153 & 14.154 & & \\
\hline & PIE-Robot & 0.001 & 0.004 & 0.002 & 0.004 & 0.003 & 0.004 & 0.003 & \pm 0.001 \\
\hline \multirow[t]{3}{*}{$C-F$} & Robot & 14.150 & 14.151 & 14.154 & 14.153 & 14.154 & 14.157 & & \\
\hline & PIE & 14.159 & 14.157 & 14.154 & 14.154 & 14.152 & 14.151 & & \\
\hline & PIE-Robot & 0.009 & 0.006 & 0 & 0.001 & -0.002 & -0.006 & 0.001 & \pm 0.005 \\
\hline $\begin{array}{l}\text { Block } \\
\text { Average }\end{array}$ & PIE-Robot & & & & & & & 0.002 & \pm 0.004 \\
\hline
\end{tabular}

(a) All dimensions in inches. 
TABLE 6-4

COMPARISON OF ROBOT AND HOT CELL LENGTH

MEASUREMENTS FOR SURVEILLANCE ELEMENT

S/N 1-0743

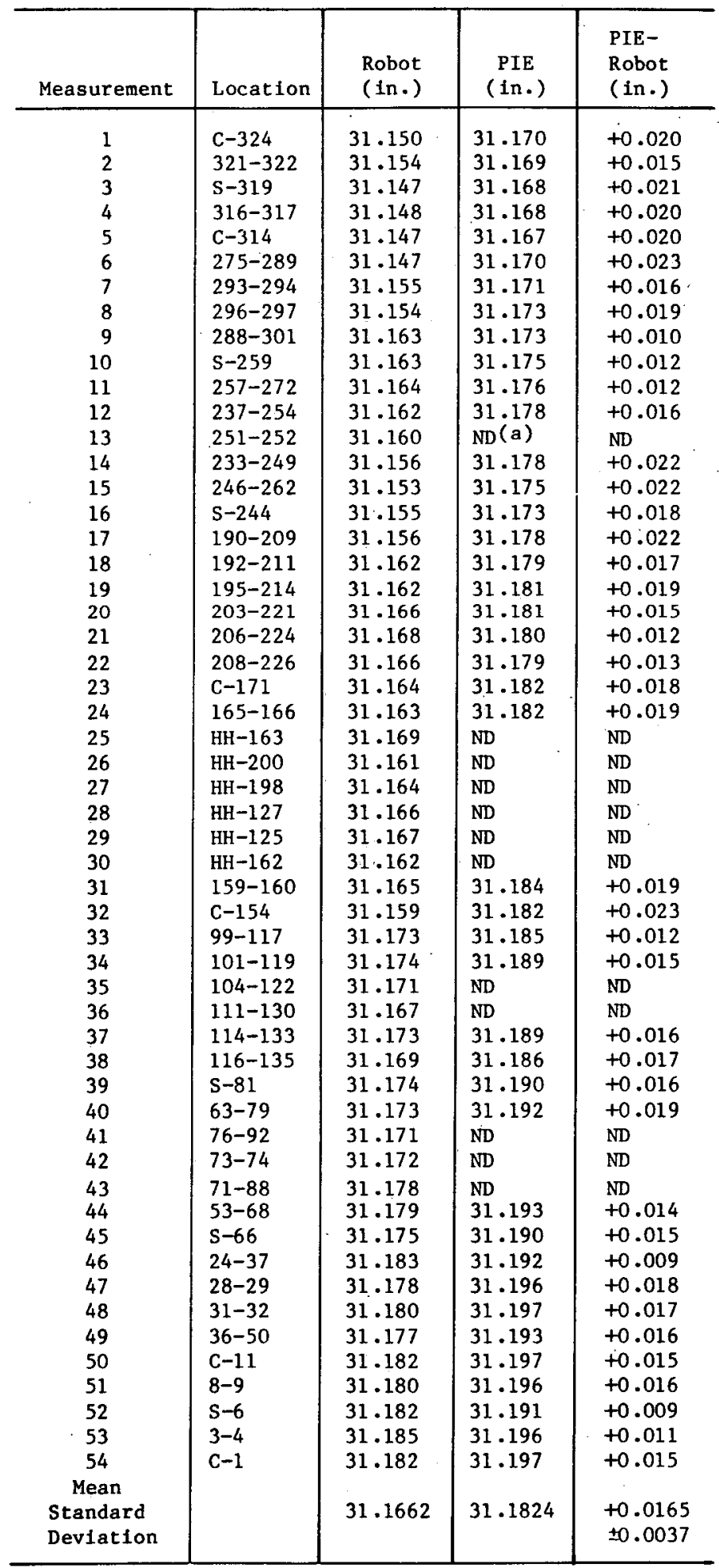

(a) $N D=$ Not determined. 
TABLE 6-5

COMPARISON OF ROBOT AND HOT CELL COOLANT HOLE DIAMETER MEASUREMENTS FOR SURVEILLANCE ELEMENT S/N 1-0743

\begin{tabular}{|c|c|c|c|}
\hline \multirow[b]{2}{*}{ Hole } & \multicolumn{3}{|c|}{$\begin{array}{c}\text { Coolant Hole Diameters } \\
\text { (Inches) }\end{array}$} \\
\hline & Robot & PIE & PIE-Robot \\
\hline 6 & 0.625 & 0.623 & -0.002 \\
\hline 13 & 0.625 & 0.623 & -0.002 \\
\hline 22 & 0.626 & 0.622 & -0.004 \\
\hline 30 & 0.624 & 0.623 & -0.001 \\
\hline 55 & 0.623 & 0.622 & -0.001 \\
\hline 58 & 0.625 & 0.623 & -0.002 \\
\hline 61 & 0.625 & 0.622 & -0.003 \\
\hline 66 & 0.624 & 0.623 & -0.001 \\
\hline 81 & 0.624 & 0.623 & -0.001 \\
\hline 90 & 0.624 & 0.623 & -0.001 \\
\hline 103 & 0.624 & 0.623 & -0.001 \\
\hline 106 & 0.624 & 0.623 & -0.001 \\
\hline 109 & 0.624 & 0.623 & -0.001 \\
\hline 112 & 0.625 & 0.622 & -0.003 \\
\hline 126 & 0.499 & 0.498 & -0.001 \\
\hline 144 & 0.500 & 0.497 & -0.003 \\
\hline 145 & 0.499 & 0.498 & -0.001 \\
\hline 155 & 0.623 & 0.623 & 0 \\
\hline 158 & 0.623 & 0.623 & 0 \\
\hline 161 & 0.623 & 0.623 & 0 \\
\hline 164 & 0.624 & 0.622 & -0.002 \\
\hline 167 & 0.624 & 0.623 & -0.001 \\
\hline 170 & 0.624 & 0.623 & -0.001 \\
\hline 180 & 0.500 & 0.497 & -0.003 \\
\hline 181 & 0.499 & 0.498 & -0.001 \\
\hline 199 & 0.499 & 0.497 & -0.002 \\
\hline 213 & 0.623 & 0.623 & 0 \\
\hline 216 & 0.624 & 0.623 & -0.001 \\
\hline 219 & 0.624 & 0.623 & -0.001 \\
\hline 222 & 0.624 & 0.623 & -0.001 \\
\hline 235 & 0.624 & 0.623 & -0.001 \\
\hline 244 & 0.624 & 0.622 & -0.002 \\
\hline 259 & 0.624 & 0.623 & -0.001 \\
\hline 264 & 0.623 & 0.623 & 0 \\
\hline 267 & 0.622 & 0.622 & 0 \\
\hline 270 & 0.623 & 0.622 & -0.001 \\
\hline 295 & 0.625 & 0.623 & -0.002 \\
\hline 303 & 0.623 & 0.622 & -0.001 \\
\hline 312 & 0.624 & 0.623 & -0.001 \\
\hline 319 & 0.622 & 0.622 & 0 \\
\hline Average & & & -0.001 \\
\hline Std Dev. & & & \pm 0.001 \\
\hline
\end{tabular}


TABLE 6-6

ROBOT AND HOT CELL BOW MEASUREMENTS FOR SURVEILLANCE ELEMENT S/N $1-0743$

(Inches) (a)

\begin{tabular}{|c|c|c|c|c|c|c|c|c|c|c|c|c|}
\hline \multirow[b]{2}{*}{ Position } & \multicolumn{2}{|c|}{ Face A } & \multicolumn{2}{|c|}{ Face B } & \multicolumn{2}{|c|}{ Face C } & \multicolumn{2}{|c|}{ Face D } & \multicolumn{2}{|c|}{ Face E } & \multicolumn{2}{|c|}{ Face $F$} \\
\hline & Robot $^{(b)}$ & PIE & Robot & PIE & Robot & PIE & Robot & PIE & Robot & PIE & Robot & PIE \\
\hline $6^{(c)}$ & +0.0040 & +0.0036 & +0.0047 & +0.0047 & +0.0044 & +0.0021 & -0.0016 & -0.0019 & -0.0026 & -0.0034 & -0.0004 & -0.0018 \\
\hline 7 & +0.0049 & +0.0023 & +0.0064 & +0.0046 & +0.0042 & +0.0021 & -0.0017 & -0.0018 & -0.0006 & -0.0031 & -0.0003 & -0.0020 \\
\hline 8 & +0.0050 & +0.0023 & +0.0074 & +0.0019 & +0.0042 & +0.0028 & -0.0008 & -0.0014 & -0.0024 & -0.0047 & -0.0012 & -0.0021 \\
\hline 9 & +0.0049 & +0.0026 & +0.0055 & +0.0043 & +0.0044 & +0.0031 & -0.0007 & -0.0016 & -0.0025 & -0.0035 & -0.0002 & -0.0021 \\
\hline 10 & +0.0031 & +0.0019 & +0.0066 & +0.0047 & +0.0053 & +0.0032 & +0.0015 & -0.0009 & -0.0024 & -0.0034 & -0.0013 & -0.0021 \\
\hline 11 & +0.0052 & +0.0034 & +0.0112 & +0.0081 & +0.0076 & +0.0053 & 0 & -0.0017 & -0.0048 & -0.0063 & -0.0016 & -0.0039 \\
\hline 12 & +0.0068 & +0.0044 & +0.0100 & +0.0077 . & $+0.005 B$ & +0.0052 & +0.0006 & -0.0027 & -0.0040 & -0.0057 & -0.0024 & -0.0040 \\
\hline 13 & +0.0060 & +0.0041 & +0.0118 & +0.0039 & +0.0074 & +0.0045 & -0.0016 & -0.0027 & -0.0028 & -0.0066 & -0.0024 & -0.0040 \\
\hline 14 & +0.0058 & +0.0037 & +0.0108 & +0.0074 & +0.0074 & +0.0044 & -0.0014 & -0.0033 & -0.0042 & -0.0059 & -0.0006 & -0.0033 \\
\hline 15 & +0.0070 & +0.0056 & +0.0094 & +0.0079 & +0.0068 & +0.0037 & -0.0022 & -0.0031 & -0.0032 & -0.0066 & +0.0002 & -0.0030 \\
\hline 16 & +0.0090 & +0.0066 & +0.0121 & +0.0097 & +0.0092 & +0.0054 & -0.0028 & -0.0040 & -0.0058 & -0.0088 & +0.0008 & -0.0040 \\
\hline 17 & +0.0087 & +0.0048 & +0.0132 & +0.0093 & +0.0106 & +0.0055 & -0.0021 & -0.0044 & -0.0048 & -0.0084 & -0.0009 & -0.0044 \\
\hline 18 & +0.0080 & +0.0055 & +0.0132 & +0.0058 & +0.0086 & +0.0058 & -0.0004 & -0.0034 & -0.0052 & -0.0096 & -0.0026 & -0.0052 \\
\hline 19 & +0.0087 & +0.0053 & +0.0125 & +0.0098 & +0.0092 & +0.0063 & -0.0001 & -0.0032 & -0.0055 & -0.0084 & -0.0016 & -0.0051 \\
\hline 20 & +0.0073 & +0.0046 & +0.0128 & +0.0100 & +0.0089 & +0.0065 & +0.0005 & -0.0023 & -0.0062 & -0.0087 & -0.0019 & -0.0052 \\
\hline 21 & +0.0084 & +0.0054 & +0.0144 & +0.0110 & +0.0092 & +0.0073 & 0 & -0.0027 & -0.0066 & -0.0099 & -0.0032 & -0.0058 \\
\hline 22 & +0.0086 & $+0,0060$ & +0.0150 & +0.0111 & +0.0106 & +0.0068 & +0.0002 & -0.0035 & -0.0070 & -0.0100 & -0.0018 & -0.0056 \\
\hline 23 & +0.0090 & +0.0064 & +0.0146 & +0.0078 & +0.0098 & +0.0066 & -0.0002 & -0.0038 & -0.0066 & -0.0109 & -0.0018 & -0.0058 \\
\hline 24 & +0.0096 & +0.0058 & +0.0136 & +0.0106 & +0.0108 & +0.0067 & -0.0008 & -0.0049 & -0.0064 & -0.0098 & -0.0002 & -0.0052 \\
\hline 25 & +0.0100 & +0.0069 & +0.0138 & +0.0109 & +0.0096 & +0.0062 & -0.0014 & -0.0047 & -0.0064 & -0.0101 & +0.0004 & -0.0045 \\
\hline 26 & +0.0100 & +0.0070 & +0.0145 & +0.0114 & +0.0110 & +0.0064 & -0.0020 & -0.0047 & -0.0070 & -0.0107 & -0.0010 & -0.0042 \\
\hline 27 & +0.0095 & +0.0059 & +0.0150 & +0.0109 & +0.0110 & +0.0067 & -0.0015 & -0.0015 & -0.0060 & -0.0103 & -0.0015 & -0.0053 \\
\hline 28 & +0.0090 & +0.0058 & +0.0140 & +0.0097 & +0.0100 & +0.0069 & 0 & -0.0042 & -0.0060 & -0.0113 & -0.0020 & -0.0060 \\
\hline 29 & +0.0095 & +0.0060 & +0.0135 & +0.0109 & +0.0110 & +0.0070 & +0.0005 & -0.0039 & -0.0065 & -0.0105 & -0.0020 & -0.0060 \\
\hline 30 & +0.0085 & +0.0054 & +0.0140 & +0.0113 & +0.0095 & +0.0074 & +0.0015 & -0.0028 & -0.0070 & -0.0104 & -0.0035 & -0.0064 \\
\hline 31 & +0.0086 & +0.0053 & +0.0136 & +0.0106 & +0.0088 & +0.0068 & +0.0010 & -0.0026 & -0.0064 & -0.0097 & -0.0028 & -0.0059 \\
\hline 32 & +0.0074 & +0.0057 & +0.0130 & +0.0101 & +0.0094 & +0.0065 & -0.0002 & -0.0036 & -0.0060 & -0.0099 & -0.0032 & -0.0056 \\
\hline 33 & +0.0080 & +0.0057 & +0.01 & +0.0111 & +0.00 & +0.0064 & -0.0018 & -0.0035 & -0.0064 & -0.0108 & -0.0032 & -0.0052 \\
\hline 34 & +0.0084 & +0.0056 & +0.0124 & +0.0104 & +0.0092 & +0.0063 & -0.0012 & -0.0049 & -0.0066 & -0.0098 & -0.0008 & -0.0046 \\
\hline 35 & +0.0090 & +0.0066 & +0.0122 & +0.0104 & +0.0104 & +0.0059 & -0.0016 & -0.0042 & -0.0066 & -0.0097 & +0.0046 & -0.0039 \\
\hline 36 & +0.0070 & +0.0056 & +0.0089 & +0.0088 & +0.0088 & +0.0050 & -0.0022 & $-0.004 i$ & -0.0062 & -0.0084 & -0.0008 & -0.0028 \\
\hline 37 & +0.0073 & +0.0051 & +0.0098 & +0.0083 & +0.0074 & +0.0052 & -0.0019 & -0.0041 & -0.0062 & -0.0083 & -0.0021 & -0.0042 \\
\hline 38 & +0.0060 & +0.0049 & +0.0098 & +0.0092 . & +0.0064 & +0.0052 & -0.0016 & -0.0037 & -0.0058 & -0.0089 & -0.0024 & -0.0048 \\
\hline 39 & +0.0073 & +0.0050 & +0.0105 & +0.0081 & +0.0068 & +0.0055 & -0.0009 & -0.0032 & -0.0065 & -0.0081 & -0.0024 & -0.0036 \\
\hline 40 & +0.0057 & +0.0046 & +0.0102 & +0.0089 & +0.0061 & +0.0059 & -0.0005 & -0.0021 & -0.0058 & -0.0080 & -0.0031 & -0.0053 \\
\hline 41 & +0.0038 & +0.0032 & +0.0068 & +0.0058 & +0.0044 & +0.0041 & 0 & -0.0012 & -0.0032 & -0.0052 & -0.0034 & -0.0036 \\
\hline 42 & +0.0032 & & +0.0070 & +0.0054 & +0.0052 & +0.0036 & -0.0006 & -0.0022 & -0.0050 & -0.0053 & -0.0016 & -0.0020 \\
\hline 43 & +0.0040 & +0.0036 & +0.0062 & +0.0063 & +0.0046 & +0.0040 & -0.0024 & -0.0026 & -0.0032 & -0.0056 & -0.0026 & -0.0033 \\
\hline 44 & +0.0052 & +0.0037 & +0.0072 & +0.0053 & +0.0046 & +0.0039 & -0.0016 & -0.0031 & -0.0048 & -0.0055 & -0.0014 & -0.0027 \\
\hline 45 & +0.0040 & +0.0040 & +0.0056 & +0.0060 & +0.0052 & +0.0035 & -0.0008 & -0.0025 & -0.0058 & -0.0061 & -0.0002 & -0.0019 \\
\hline 46 & +0.0020 & +0.0018 & +0.0013 & +0.0025 & +0.0016 & +0.0014 & -0.0014 & -0.0006 & -0.0032 & -0.0025 & -0.0006 & -0.0003 \\
\hline 47 & +0.0021 & +0.0017 & +0.0026 & +0.0023 & +0.0008 & +0.0018 & -0.0013 & -0.0010 & -0.0014 & -0.0020 & -0.0007 & -0.0007 \\
\hline 48 & +0.0010 & +0.0017 & +0.0026 & +0.0028 & +0.0008 & +0.0017 & -0.0012 & -0.0008 & -0.0006 & -0.0025 & +0.0022 & -0.0012 \\
\hline 49 & +0.0011 & +0.0018 & +0.0025 & +0.0021 & +0.0016 & +0.0018 & -0.0003 & -0.0006 & -0.0025 & -0.0019 & -0.0008 & -0.0011 \\
\hline 50 & +0.0019 & +0.0017 & +0.0024 & -0.0021 & -0.0003 & +0.0017 & +0.0005 & 0 & -0.0016 & -0.0014 & -0.0017 & -0.0015 \\
\hline Mean $(d)$ & +0.0064 & +0.0045 & +0.0099 & +0.0075 & +0.0070 & +0.0049 & -0.0008 & -0.0029 & -0.0048 & -0.0073 & -0.0013 & -0.0038 \\
\hline Std. Dev. & 0.0026 & 0.0016 & 0.0040 & 0.0033 & 0.0031 & 0.0018 & 0.0010 & 0.0013 & 0.0019 & 0.0029 & 0.0015 & 0.0016 \\
\hline
\end{tabular}

(a) If bow is $t$, surface is concave; if bow is -, surface is convex.

(b) Robot measurements not corrected for bias in robot bow measurements.

(c) Positions $1-5$ and $51-55$ have zero values.

(d) Excluding $1-5$ and $51-55$. 
TABLE 6-7

COMPARISON OF ROBOT AND BOT CELL BOW MEASUREMENTS FOR SURVEILLANCE ELEMENT S/N 1-0743

\begin{tabular}{|c|c|c|c|c|c|c|c|}
\hline \multirow[b]{2}{*}{ Posteion } & \multicolumn{7}{|c|}{$\begin{array}{l}\text { PIE-Robot (a) } \\
\text { (Inches) }\end{array}$} \\
\hline & Face A & Face B & Pace C & Face D & Face $\mathrm{E}$ & Pace $\mathbf{P}$ & $\begin{array}{l}\text { Block } \\
\text { Average }\end{array}$ \\
\hline $6(b)$ & 0.001 & 0.001 & -0.001 & 0.001 & 0.000 & 0.000 & \\
\hline 7 & -0.002 & -0.001 & -0.001 & 0.001 & -0.002 & -0.001 & \\
\hline 8 & -0.002 & -0.005 & 0.000 & 0.000 & -0.001 & 0.000 & \\
\hline 9 & -0.001 & 0.000 & 0.000 & 0.000 & 0.000 & -0.001 & \\
\hline 10 & 0.000 & -0.001 & -0.001 & -0.001 & 0.000 & 0.000 & \\
\hline 11 & 0.000 & -0.001 & 0.000 & 0.000 & 0.001 & 0.000 & \\
\hline 12 & 0.000 & 0.000 & 0.001 & -0.001 & 0.000 & 0.000 & \\
\hline 13 & 0.000 & -0.006 & -0.001 & 0.001 & 0.002 & 0.000 & \\
\hline 14 & 0.000 & -0.001 & -0.001 & 0.000 & 0.000 & -0.001 & \\
\hline 15 & 0.001 & 0.001 & -0.001 & 0.001 & -0.001 & -0.001 & \\
\hline 16 & 0.000 & 0.000 & -0.002 & 0.001 & -0.001 & -0.003 & \\
\hline 17 & -0.002 & -0.002 & -0.003 & 0.000 & -0.002 & -0.002 & \\
\hline 18 & 0.000 & -0.005 & -0.001 & -0.001 & -0.002 & -0.001 & \\
\hline 19 & -0.001 & -0.001 & -0.001 & -0.001 & -0.001 & -0.002 & \\
\hline 20 & -0.001 & -0.001 & 0.000 & -0.001 & 0.001 & -0.001 & \\
\hline 21 & 0.000 & 0.000 & 0.001 & 0.000 & 0.000 & 0.000 & \\
\hline 22 & 0.000 & -0.001 & -0.001 & -0.001 & 0.000 & -0.001 & \\
\hline 23 & 0.000 & -0.004 & 0.000 & -0.001 & -0.001 & -0.001 & \\
\hline 24 & -0.001 & 0.000 & -0.002 & -0.001 & 0.000 & -0.002 & \\
\hline 25 & 0.000 & 0.000 & 0.000 & 0.000 & -0.001 & -0.002 & \\
\hline 26 & 0.000 & 0.000 & -0.002 & 0.000 & -0.001 & 0.000 & \\
\hline 27 & -0.001 & -0.001 & -0.001 & -0.001 & -0.001 & -0.001 & \\
\hline 28 & 0.000 & -0.001 & -0.001 & -0.001 & -0.002 & -0.001 & \\
\hline 29 & -0.001 & 0.000 & -0.001 & -0.001 & -0.001 & -0.001 & \\
\hline 30 & 0.000 & 0.000 & 0.001 & -0.001 & 0.000 & 0.000 & \\
\hline 31 & -0.001 & -0.001 & 0.000 & -0.002 & -0.001 & -0.001 & \\
\hline 32 & 0.001 & -0.001 & -0.001 & -0.001 & -0.002 & 0.000 & \\
\hline 33 & 0.000 & 0.001 & 0.000 & 0.000 & -0.002 & 0.000 & \\
\hline 34 & -0.001 & 0.000 & -0.001 & -0.002 & -0.001 & -0.002 & \\
\hline 35 & 0.000 & 0.000 & -0.002 & -0.001 & -0.001 & -0.006 & \\
\hline 36 & 0.001 & 0.002 & -0.002 & 0.000 & 0.000 & 0.000 & \\
\hline 37 & 0.000 & 0.001 & 0.000 & 0.000 & 0.000 & 0.000 & \\
\hline 38 & 0.001 & 0.001 & 0.001 & 0.000 & -0.001 & 0.000 & \\
\hline 39 & 0.000 & 0.000 & 0.001 & 0.000 & 0.000 & 0.001 & \\
\hline 40 & 0.001 & 0.001 & 0.002 & 0.000 & 0.000 & 0.000 & \\
\hline 41 & 0.000 & 0.000 & 0.001 & 0.000 & -0.001 & 0.001 & \\
\hline 42 & 0.001 & -0.001 & -0.001 & -0.001 & 0.001 & 0.001 & \\
\hline 43 & 0.001 & 0.001 & 0.000 & 0.001 & -0.001 & 0.000 & . \\
\hline 44 & -0.001 & -0.001 & 0.000 & -0.001 & 0.000 & 0.000 & \\
\hline 45 & 0.001 & 0.001 & -0.001 & -0.001 & 0.001 & -0.001 & \\
\hline 46 & 0.000 & 0.001 & 0.000 & 0.001 & 0.001 & 0.000 & \\
\hline 47 & 0.000 & 0.000 & 0.001 & 0.000 & 0.001 & 0.000 & \\
\hline 48 & 0.001 & 0.000 & 0.001 & 0.000 & -0.002 & -0.003 & \\
\hline 49 & 0.001 & 0.000 & 0.000 & 0.000 & 0.001 & 0.000 & . \\
\hline 50 & 0.000 & 0.000 & 0.002 & -0.001 & 0.000 & 0.000 & \\
\hline Average & 0.000 & -0.001 & 0.000 & 0.000 & -0.001 & -0.001 & 0.000 \\
\hline $\begin{array}{l}\text { Standard } \\
\text { Deviation }\end{array}$ & \pm 0.001 & \pm 0.002 & \pm 0.001 & \pm 0.001 & \pm 0.001 & \pm 0.001 & \pm 0.001 \\
\hline
\end{tabular}

\footnotetext{
(a) Robot measurements corrected for bias in robot bow
} measurements.

(b) Positions $1-5$ and 51-55 have zero values. 
TABLE 6-8

DISTANCE BETWEEN FIDUCIAL HOLE MEASUREMENTS FOR CALIBRATION ELEMENT S/N 8-0182

\begin{tabular}{|c|c|c|c|c|c|c|c|c|c|}
\hline \multirow[b]{2}{*}{ Corner } & \multirow[b]{2}{*}{ Dimension } & \multirow[b]{2}{*}{ QC } & \multicolumn{7}{|c|}{$\begin{array}{c}\text { Robot Measurements } \\
\text { (Inches) }\end{array}$} \\
\hline & & & Inspection 1 & Inspection 2 & Inspection 3 & Inspection 4 & Inspection 5 & Average & $\begin{array}{c}\text { Standard } \\
\text { Deviation }( \pm)\end{array}$ \\
\hline \multirow[t]{3}{*}{1} & $\mathbf{L}$ & 9.003 & 9.002 & 8.999 & 9.001 & 9.000 & 9.001 & 9.001 & 0.001 \\
\hline & $\mathbf{M}$ & 9.002 & 9.005 & 9.008 & 9.001 & 8.997 & 9.005 & 9.003 & 0.004 \\
\hline & $\mathbf{N}$ & 9.000 & 9.003 & 8.999 & 9.000 & 9.007 & 9.002 & 9.002 & 0.003 \\
\hline \multirow[t]{2}{*}{2} & L & 9.003 & 8.996 & 8.997 & 9.005 & 9.001 & 8.995 & 8.999 & 0.004 \\
\hline & $M$ & 9.001 & 9.003 & 9.001 & 9.001 & 8.995 & 9.005 & 9.001 & 0.004 \\
\hline \multirow{3}{*}{3} & $\mathbf{N}$ & 9.000 & 9.005 & 9.003 & 8.999 & 9.003 & 9.001 & 9.002 & 0.002 \\
\hline & $\mathbf{L}$ & 9.003 & 9.000 & 8.998 & 9.003 & 9.004 & 9.006 & 9.002 & 0.003 \\
\hline & M & 9.001 & 9.002 & 9.001 & 9.000 & 9.000 & 9.003 & 9.001 & 0.001 \\
\hline \multirow{4}{*}{4} & $\mathbf{N}$ & 9.001 & 8.999 & 9.002 & 9.005 & 9.001 & 8.999 & 9.001 & 0.002 \\
\hline & $\mathbf{L}$ & 9.004 & 9.002 & 9.000 & 9.004 & 9.001 & 9.002 & 9.002 & 0.002 \\
\hline & $\mathbf{M}$ & 9.001 & 9.004 & 9.004 & 9.004 & 9.004 & 9.002 & 9.004 & 0.001 \\
\hline & $\mathbf{N}$ & 9.001 & 8.999 & 9.001 & 8.996 & 8.998 & 9.001 & 8.999 & 0.002 \\
\hline \multirow[t]{3}{*}{5} & L & 9.004 & 9.007 & 9.007 & 8.999 & 8.996 & 9.001 & 9.002 & 0.005 \\
\hline & $\mathbf{M}$ & 9.002 & 9.004 & 8.998 & 9.005 & 9.005 & 9.003 & 9.003 & 0.003 \\
\hline & $\mathbf{N}$ & 9.001 & 9.000 & 9.003 & 9.002 & 9.002 & 9.006 & 9.003 & 0.002 \\
\hline \multirow[t]{3}{*}{6} & L & 9.002 & 8.999 & 8.994 & 8.999 & 9.006 & 9.000 & 9.000 & 0.004 \\
\hline & $\mathbf{M}$ & 9.002 & 8.999 & 9.001 & 9.000 & 8.998 & 9.002 & 9.000 & 0.002 \\
\hline & $\mathrm{N}$ & 9.001 & 9.000 & 9.004 & 9.002 & 9.004 & 9.001 & 9.002 & 0.002 \\
\hline
\end{tabular}


TABLE 6-9

COMPARISON OF ROBOT AND QC DISTANCE BETWEEN FIDUCIAL HOLE MEASUREMENTS FOR CALIBRATION ELEMENT S/N 8-0182

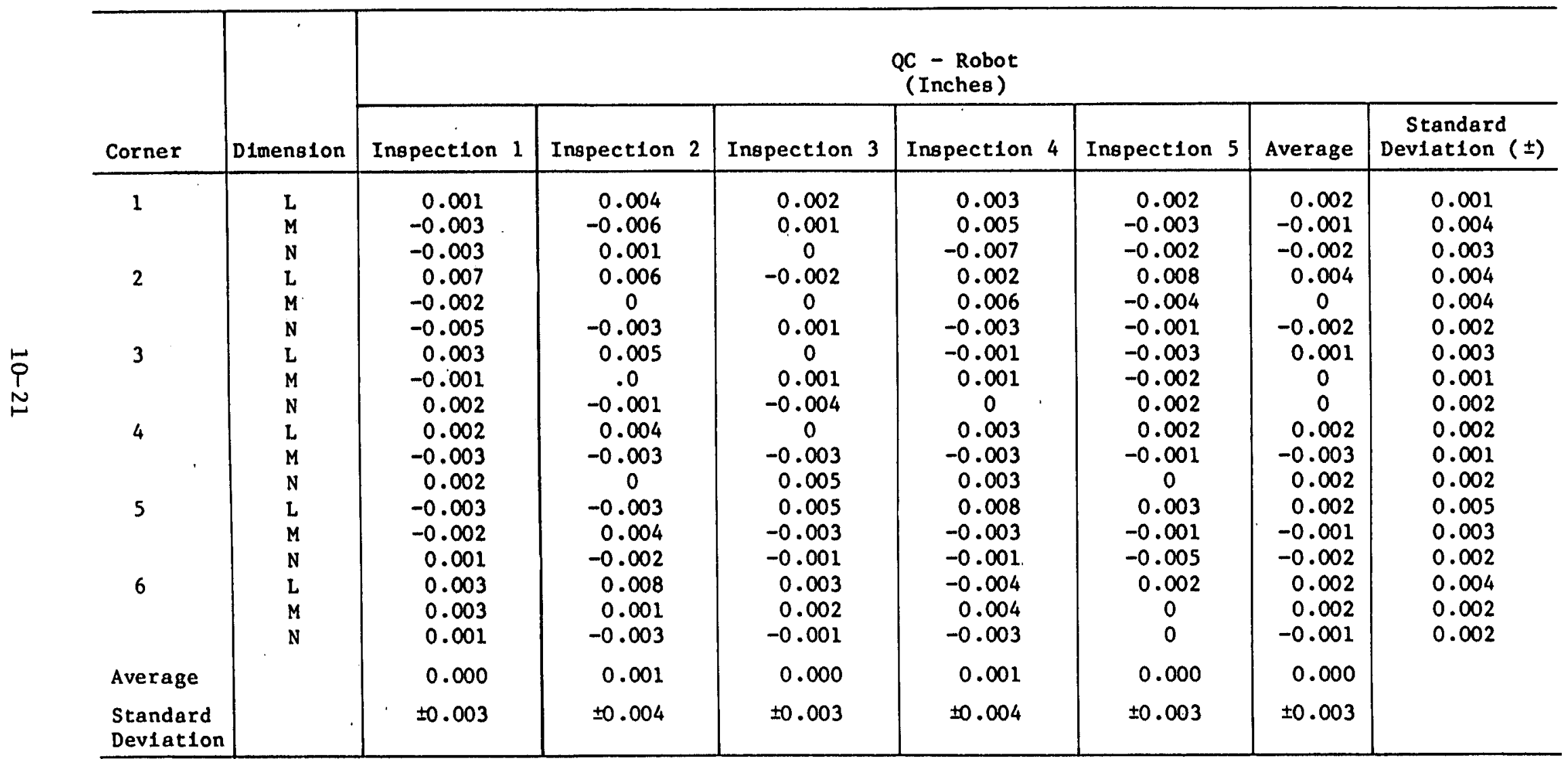


TABLE 6-10

ACROSS-FLATS MEASUREMENTS FOR CALIBRATION ELEMENT S/N 8-0182

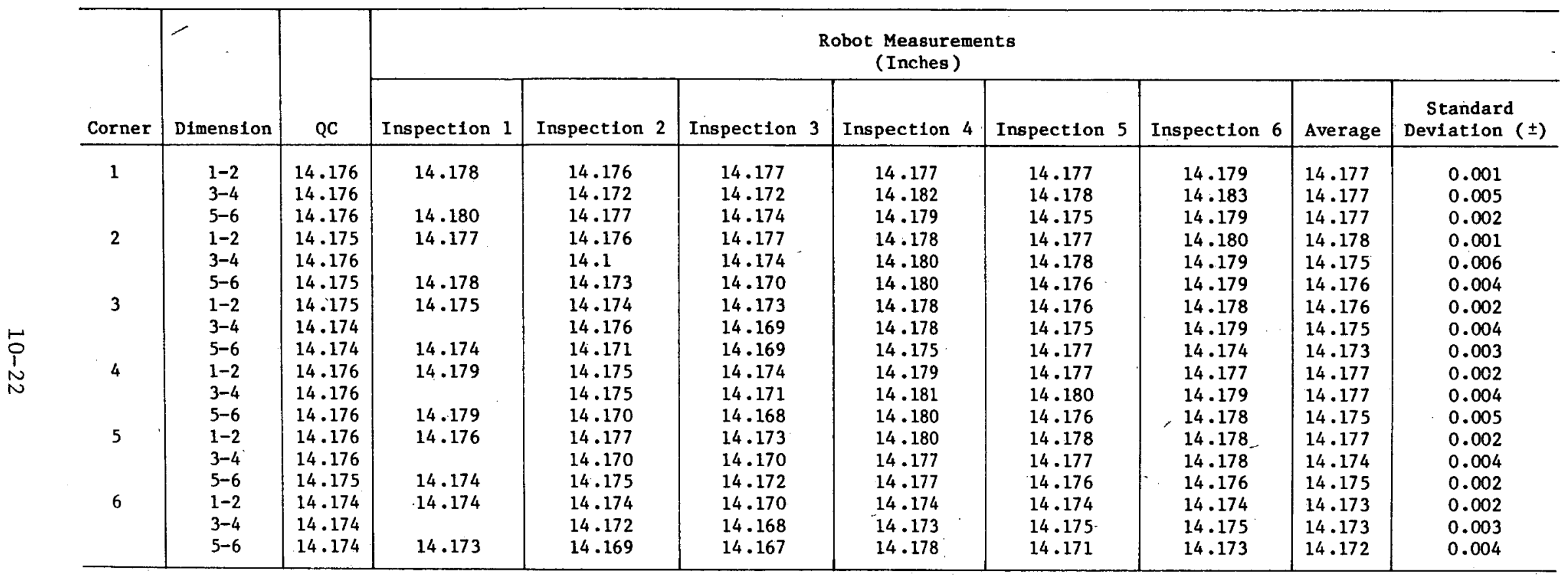


TABLE 6-11

COMPARISON OF ROBOT AND QC ACROSS-FLATS MEASUREMENTS FOR CALIBRATION ELEMENT S/N 8-0182

\begin{tabular}{|c|c|c|c|c|c|c|c|c|c|}
\hline \multirow[b]{2}{*}{ Corner } & \multirow[b]{2}{*}{ Dimenston } & \multicolumn{8}{|c|}{$\begin{array}{c}Q C \text { - Robot } \\
\text { (Inches) }\end{array}$} \\
\hline & & Inspection 1 & Inspection 2 & Inspection 3 & Inspection 4 & Inspection 5 & Inspection 6 & Average & $\begin{array}{c}\text { Standard } \\
\text { Deviation ( }( \pm)\end{array}$ \\
\hline $\begin{array}{l}5 \\
6\end{array}$ & $\begin{array}{l}1-2 \\
3-4 \\
5-6 \\
1-2 \\
3-4 \\
5-6 \\
1-2 \\
3-4 \\
5-6 \\
1-2 \\
3-4 \\
5-6 \\
1-2 \\
3-4 \\
5-6 \\
1-2 \\
3-4 \\
5-6\end{array}$ & $\begin{array}{l}-0.002 \\
-0.004 \\
-0.002 \\
-0.003 \\
0 \\
0 \\
-0.003 \\
-0.003 \\
0 \\
0 \\
0.001 \\
0 \\
0.001\end{array}$ & $\begin{array}{r}0 \\
0.004 \\
-0.001 \\
-0.001 \\
+0.010 \\
0.002 \\
0.001 \\
-0.002 \\
0.003 \\
0.001 \\
0.001 \\
0.006 \\
-0.001 \\
0.006 \\
0 \\
0 \\
0.002 \\
0.005\end{array}$ & $\begin{array}{r}-0.001 \\
0.004 \\
0.002 \\
-0.002 \\
0.002 \\
0.005 \\
0.002 \\
0.005 \\
0.005 \\
0.002 \\
0.005 \\
0.008 \\
0.003 \\
0.006 \\
0.003 \\
0.004 \\
0.006 \\
0.007\end{array}$ & $\begin{array}{r}-0.001 \\
-0.006 \\
-0.003 \\
-0.003 \\
-0.004 \\
-0.005 \\
-0.003 \\
-0.004 \\
-0.001 \\
-0.003 \\
-0.005 \\
-0.004 \\
-0.004 \\
-0.001 \\
-0.002 \\
0 \\
0.001 \\
-0.004\end{array}$ & $\begin{array}{r}-0.001 \\
-0.002 \\
0.001 \\
-0.002 \\
-0.002 \\
-0.001 \\
-0.001 \\
-0.001 \\
-0.003 \\
-0.001 \\
-0.004 \\
0 \\
-0.002 \\
-0.001 \\
-0.001 \\
0 \\
-0.001 \\
0.003\end{array}$ & $\begin{array}{c}-0.003 \\
-0.007 \\
-0.003 \\
-0.005 \\
-0.003 \\
-0.004 \\
-0.003 \\
-0.005 \\
0 \\
-0.001 \\
-0.003 \\
-0.002 \\
-0.002 \\
-0.002 \\
-0.001 \\
0 \\
-0.001 \\
0.001\end{array}$ & $\begin{array}{r}-0.001 \\
-0.001 \\
-0.001 \\
-0.002 \\
0.001 \\
-0.001 \\
-0.001 \\
-0.001 \\
0.001 \\
-0.001 \\
-0.001 \\
0.001 \\
-0.001 \\
0.002 \\
0 \\
0.001 \\
0.001 \\
0.002\end{array}$ & $\begin{array}{l}0.001 \\
0.005 \\
0.002 \\
0.001 \\
0.006 \\
0.004 \\
0.002 \\
0.004 \\
0.003 \\
0.002 \\
0.004 \\
0.005 \\
0.002 \\
0.004 \\
0.002 \\
0.002 \\
0.003 \\
0.004\end{array}$ \\
\hline \multicolumn{2}{|c|}{$\begin{array}{l}\text { Average Standard } \\
\text { Deviation }\end{array}$} & $\begin{array}{l}-0.001 \\
\pm 0.002\end{array}$ & $\begin{array}{r}0.002 \\
\pm 0.003\end{array}$ & $\begin{array}{r}0.004 \\
\pm 0.003\end{array}$ & $\begin{array}{l}-0.003 \\
\pm 0.002\end{array}$ & $\begin{array}{l}-0.001 \\
\pm 0.002\end{array}$ & $\begin{array}{l}-0.002 \\
\pm 0.002\end{array}$ & $\begin{array}{l}0 \\
\pm 0.003\end{array}$ & \\
\hline
\end{tabular}


TABLE 6-12

LENGTH MEASUREMENTS FOR CALIBRATION ELEMENT S/N 8-0182

\begin{tabular}{|c|c|c|c|c|c|c|c|}
\hline \multirow{2}{*}{$\begin{array}{l}\text { Measurement } \\
\text { Point }\end{array}$} & \multicolumn{7}{|c|}{ Robot Measurements (Inches) } \\
\hline & $\mathrm{QC}$ & Inspection 1 & Inspection 2 & Inspection 3 & Inspection 4 & Inspection 5 & Inspection 6 : \\
\hline 1 & 31.222 & 31.217 & 31.213 & 31.216 & 31.220 & 31.215 & 31.219 \\
\hline 2 & 31.222 & 31.214 & 31.211 & 31.209 & 31.214 & 31.212 & 31.214 \\
\hline 3 & 31.222 & 31.216 & 31.207 & 31.211 & 31.211 & 31.211 & 31.211 \\
\hline 4 & 31.222 & 31.212 & 31.207 & 31.212 & 31.214 & 31.214 & 31.209 \\
\hline 5 & 31.222 & 31.209 & 31.206 & 31.205 & 31.207 & 31.211 & 31.205 \\
\hline 6 & 31.222 & 31.215 & 31.212 & 31.211 & 31.218 & 31.217 & 31.216 \\
\hline 7 & 31.222 & 31.214 & 31.207 & 31.210 & 31.212 & 31.210 & 31.210 \\
\hline 8 & 31.222 & 31.215 & 31.213 & 31.212 & 31.217 & 31.217 & 31.215 \\
\hline 9 & 31.222 & 31.214 & 31.217 & 31.218 & 31.221 & 31.216 & 31.216 \\
\hline 10 & 31.222 & 31.227 & 31.217 & 31.226 & 31.225 & 31.224 & 31.224 \\
\hline 11 & 31.222 & 31.220 & 31.218 & 31.221 & 31.217 & 31.218 & 31.220 \\
\hline 12 & 31.222 & 31.215 & 31.215 & 31.217 & 31.217 & 31.218 & 31.212 \\
\hline 13 & 31.222 & 31.217 & 31.204 & 31.207 & 31.212 & 31.210 & 31.214 \\
\hline 14 & 31.222 & 31.216 & $31 \cdot 214$ & 31.214 & 31.218 & 31.213 & 31.217 \\
\hline 15 & 31.222 & 31.217 & 31.212 & 31.210 & 31.214 & 31.214 & 31.211 \\
\hline 16 & 31.222 & 31.215 & 31.212 & 31.207 & 31.214 & 31.214 & 31.212 \\
\hline 17 & 31.223 & 31.213 & 31.209 & 31.206 & 31.216 & 31.211 & 31.204 \\
\hline 18 & 31.222 & 31.211 & 31.205 & 31.216 & 31.218 & 31.210 & 31.211 \\
\hline 19 & 31.222 & 31.211 & 31.209 & 31.213 & 31.214 & 31.211 & 31.207 \\
\hline 20 & 31.222 & 31.220 & 31.213 & 31.215 & 31.220 & 31.215 & 31.214 \\
\hline 21 & 31.222 & 31.223 & 31.219 & 31.220 & 31.219 & 31.224 & 31.223 \\
\hline 22 & 31.223 & 31.219 & 31.216 & $31 \cdot 220$ & 31.220 & 31.221 & 31.221 \\
\hline 23 & 31.222 & 31.224 & 31.225 & 31.220 & 31.221 & 31.223 & 31.221 \\
\hline 24 & 31.222 & 31.219 & 31.218 & 31.216 & 31.221 & $31 \cdot 220$ & 31.212 \\
\hline 25 & 31.222 & 31.221 & 31.215 & 31.213 & 31.218 & 31.218 & 31.212 \\
\hline 26 & 31.222 & 31.215 & 31.210 & 31.213 & 31.212 & 31.215 & 31.215 \\
\hline 27 & 31.222 & 31.217 & 31.206 & 31.212 & 31.219 & 31.211 & 31.209 \\
\hline 28 & 31.223 & 31.214 & 31.213 & 31.217 & 31.214 & 31.216 & 31.214 \\
\hline 29 & 31.223 & 31.220 & 31.214 & 31.208 & 31.218 & 31.217 & 31.217 \\
\hline 30 & 31.222 & 31.212 & 31.214 & 31.215 & 31.215 & 31.211 & 31.214 \\
\hline 31 & 31.223 & 31.214 & 31.211 & 31.213 & 31.215 & 31.215 & 31.214 \\
\hline 32 & 31.223 & 31.213 & 31.206 & 31.207 & 31.212 & 31.204 & 31.208 \\
\hline 33 & 31.223 & 31.216 & 31.217 & 31.214 & 31.215 & $31.214^{\prime}$ & 31.213 \\
\hline 34 & 31.222 & 31.217 & 31.213 & 31.216 & 31.212 & 31.211 & 31.212 \\
\hline 35 & 31.222 & 31.213 & 31.216 & 31.212 & 31.216 & 31.215 & 31.211 \\
\hline 36 & 31.223 & 31.214 & 31.216 & 31.216 & 31.220 & 31.216 & 31.219 \\
\hline 37 & 31.222 & 31.228 & 31.226 & 31.224 & 31.224 & 31.226 & 31.225 \\
\hline 38 & 31.222 & 31.219 & 31.215 & 31.217 & 31.220 & 31.220 & 31.219 \\
\hline 39 & 31.222 & 31.219 & 31.211 & 31.213 & 31.215 & 31.211 & 31.214 \\
\hline 40 & 31.222 & 31.216 & 31.209 & 31.216 & 31.213 & 31.214 & 31.210 \\
\hline 41 & 31.223 & 31.212 & 31.213 & 31.208 & 31.209 & 31.209 & 31.208 \\
\hline 42 & 31.222 & 31.215 & 31.215 & 31.216 & 31.213 & 31.212 & 31.210 \\
\hline 43 & 31.222 & 31.216 & 31.209 & 31.211 & 31.219 & 31.214 & 31.205 \\
\hline 44 & 31.222 & 31.220 & 31.210 & 31.214 & 31.214 & 31.212 & 31.211 \\
\hline 45. & 31.222 & 31.216 & 31.211 & 31.211 & 31.216 & 31.211 & 31.213 \\
\hline 46 & 31.222 & 31.211 & 31.213 & 31.211 & 31.210 & 31.211 & 31.207 \\
\hline 47 & 31.222 & 31.218 & 31.215 & 31.220 & 31.219 & 31.214 & 31.218 \\
\hline 48 & 31.222 & 31.220 & 31.225 & $31: 217$ & 31.222 & 31.222 & 31.221 \\
\hline 49 & 31.223 & 31.220 & 31.220 & 31.217 & 31.219 & 31.214 & 31.216 \\
\hline 50 & 31.222 & 31.219 & 31.221 & 31.217 & 31.215 & 31.216 & 31.219 \\
\hline 51 & 31.222 & 31.223 & 31.220 & 31.220 & 31.214 & 31.219 & 31.214 \\
\hline 52 & 31.222 & 31.218 & 31.217 & 31.213 & 31.217 & 31.212 & 31.210 \\
\hline 53 & 31.222 & 31.213 & 31.207 & 31.211 & 31.215 & 31.214 & 31.214 \\
\hline 54 & 31.222 & 31.214 & 31.205 & 31.212 & 31.213 & 31.208 & 31.209 \\
\hline
\end{tabular}


TABIE 6-13

COYPARISON OP ROBOT AND QC LENGTB MEASUREMGATS FOR CALIBRATION S/N 8-0182

\begin{tabular}{|c|c|c|c|c|c|c|c|c|}
\hline \multirow[b]{2}{*}{$\begin{array}{l}\text { Measurement } \\
\text { Point }\end{array}$} & \multicolumn{8}{|c|}{$\begin{array}{l}\text { QC - Rabot } \\
\text { (Inches) }\end{array}$} \\
\hline & Inspection 1 & Inspection 2 & Inspect 1 on 3 & Inspection 4 & Inspection 5 & Inspection 6 & Average & $\begin{array}{c}\text { Standard } \\
\text { Deviation }( \pm)\end{array}$ \\
\hline 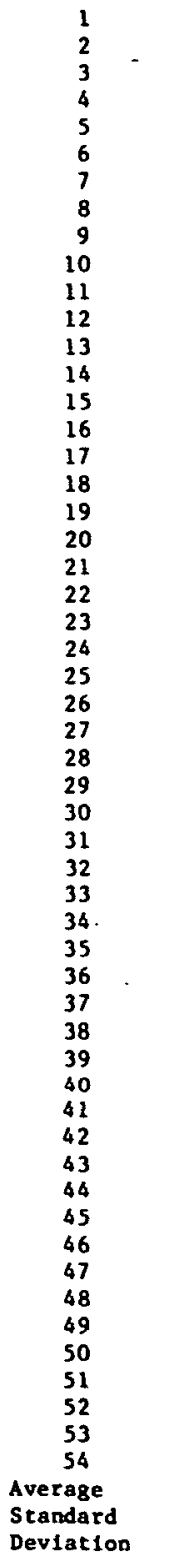 & 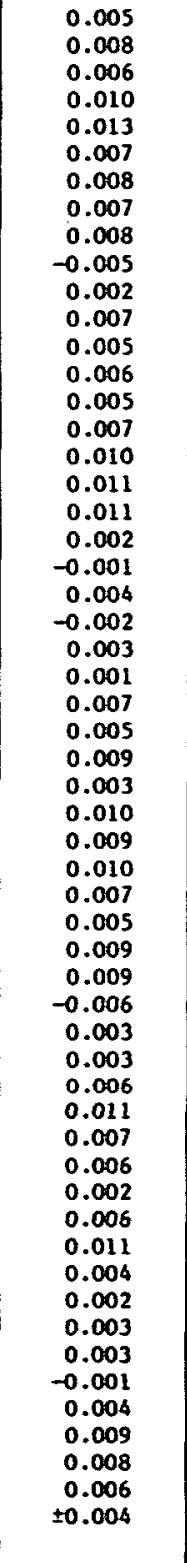 & 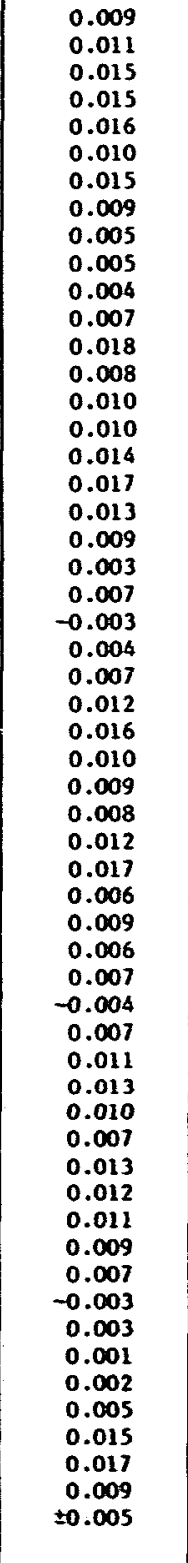 & $\begin{array}{l}0.006 \\
0.013 \\
0.011 \\
0.010 \\
0.017 \\
0.011 \\
0.012 \\
0.010 \\
0.004 \\
-0.004 \\
0.001 \\
0.005 \\
0.015 \\
0.008 \\
0.012 \\
0.015 \\
0.017 \\
0.006 \\
0.009 \\
0.007 \\
0.002 \\
0.003 \\
0.002 \\
0.006 \\
0.009 \\
0.009 \\
0.010 \\
0.006 \\
0.015 \\
0.007 \\
0.010 \\
0.016 \\
0.009 \\
0.006 \\
0.010 \\
0.007 \\
-0.002 \\
0.005 \\
0.009 \\
0.006 \\
0.015 \\
0.006 \\
0.011 \\
0.008 \\
0.011 \\
0.011 \\
0.002 \\
0.005 \\
0.006 \\
0.005 \\
0.002 \\
0.011 \\
0.010 \\
0.008 \\
0.005\end{array}$ & $\begin{array}{r}0.002 \\
0.008 \\
0.011 \\
0.003 \\
0.015 \\
0.004 \\
0.010 \\
0.005 \\
0.001 \\
-0.003 \\
0.005 \\
0.005 \\
0.010 \\
0.008 \\
0.008 \\
0.008 \\
0.007 \\
0.004 \\
0.008 \\
0.002 \\
0.003 \\
0.003 \\
0.001 \\
0.001 \\
0.004 \\
0.010 \\
0.003 \\
0.009 \\
0.005 \\
0.007 \\
0.008 \\
0.011 \\
0.008 \\
0.010 \\
0.006 \\
0.003 \\
-0.002 \\
0.002 \\
0.007 \\
0.009 \\
0.014 \\
0.009 \\
0.003 \\
0.008 \\
0.005 \\
0.012 \\
0.003 \\
0 \\
0.004 \\
0.007 \\
0.008 \\
0.005 \\
0.007 \\
0.009 \\
0.006 \\
+0.004\end{array}$ & 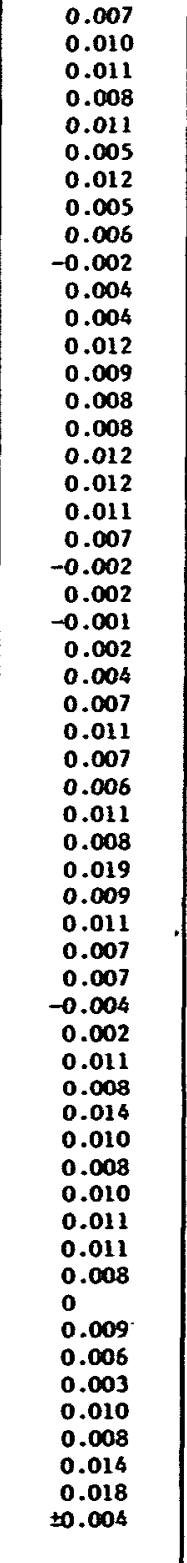 & $\begin{array}{r}0.003 \\
0.008 \\
0.011 \\
0.013 \\
0.017 \\
0.006 \\
0.012 \\
0.007 \\
0.006 \\
-0.002 \\
0.002 \\
0.010 \\
0.008 \\
0.005 \\
0.011 \\
0.010 \\
0.019 \\
0.011 \\
0.015 \\
0.008 \\
-0.001 \\
0.002 \\
0.001 \\
0.010 \\
0.010 \\
0.007 \\
0.013 \\
0.009 \\
0.006 \\
0.008 \\
0.009 \\
0.015 \\
0.010 \\
0.010 \\
0.011 \\
0.004 \\
-0.003 \\
0.003 \\
0.008 \\
0.012 \\
0.015 \\
0.012 \\
0.017 \\
0.011 \\
0.009 \\
0.015 \\
0.004 \\
0.001 \\
0.007 \\
0.003 \\
0.008 \\
0.012 \\
0.008 \\
0.013 \\
0.008 \\
\pm 0.005\end{array}$ & $\begin{array}{r}0.005 \\
0.010 \\
0.011 \\
0.011 \\
0.015 \\
0.007 \\
0.012 \\
0.007 \\
0.005 \\
-0.004 \\
0.003 \\
0.006 \\
0.011 \\
0.007 \\
0.009 \\
0.010 \\
0.013 \\
0.010 \\
0.011 \\
0.006 \\
0.001 \\
0.004 \\
0 \\
0.004 \\
0.006 \\
0.009 \\
0.010 \\
0.008 \\
0.007 \\
0.008 \\
0.009 \\
0.015 \\
0.008 \\
0.008 \\
0.008 \\
0.006 \\
-0.004 \\
0.004 \\
0.008 \\
0.009 \\
0.013 \\
0.008 \\
0.010 \\
0.008 \\
0.009 \\
0.012 \\
0.005 \\
0.001 \\
0.005 \\
0.004 \\
0.004 \\
0.008 \\
0.010 \\
0.012 \\
0.007 \\
0.05\end{array}$ & 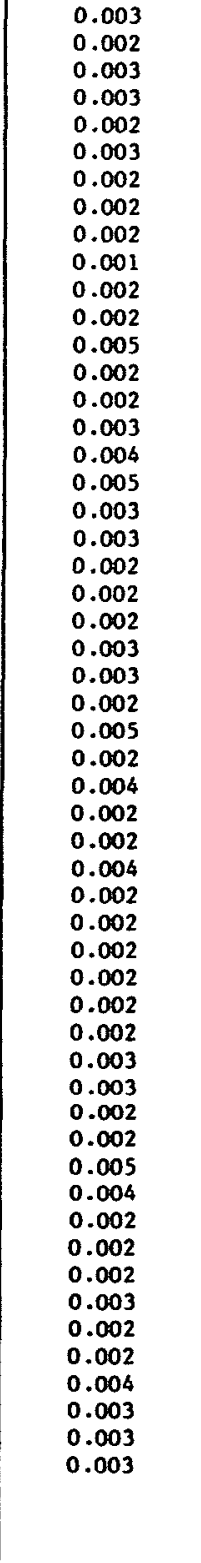 \\
\hline
\end{tabular}


TABLE 6-14

ACCURACY OF METROLOGY ROBOT MEASUREMENTS

\begin{tabular}{|c|c|c|c|c|c|c|}
\hline \multirow[b]{2}{*}{$\begin{array}{r}\text { Type of } \\
\text { Measurement }\end{array}$} & \multicolumn{3}{|c|}{ Robot vs PIE(a) } & \multicolumn{3}{|c|}{ Robot vs $Q C^{(b)}$} \\
\hline & $\begin{array}{l}\text { Number of } \\
\text { Comparisons }\end{array}$ & $\begin{array}{l}\text { Accuracy }(1 \sigma) \\
\text { (Inches) }\end{array}$ & $\begin{array}{l}\text { BIAS } \pm 1 \sigma(c) \\
\quad \text { Inches })\end{array}$ & $\begin{array}{c}\text { Number of } \\
\text { Comparisons }\end{array}$ & $\begin{array}{l}\text { Accuracy }(1 \sigma) \\
\text { (Inches) }\end{array}$ & $\begin{array}{l}\operatorname{BIAS}(d, e) \\
\text { (Inches) }\end{array}$ \\
\hline $\begin{array}{l}\text { Fuel element } \\
\text { length }\end{array}$ & 42 & \pm 0.004 & $0.011 \pm 0.001$ & 324 & \pm 0.005 & 0.007 \\
\hline $\begin{array}{l}\text { Distance between } \\
\text { fiducial holes }\end{array}$ & 18 & \pm 0.007 & $0.000 \pm 0.002$ & 90 & \pm 0.003 & 0.000 \\
\hline $\begin{array}{l}\text { Distance between } \\
\text { coolant holes }\end{array}$ & 30 & \pm 0.007 & $0.002 \pm 0.001$ & - & $\mathrm{ND}^{(\mathrm{f})}$ & ND \\
\hline $\begin{array}{l}\text { Distance across } \\
\text { flats }\end{array}$ & 15 & \pm 0.003 & $0.000 \pm 0.001$ & 102 & \pm 0.003 & 0.000 \\
\hline $\begin{array}{l}\text { Coolant hole } \\
\text { diameters }\end{array}$ & 40 & \pm 0.001 & $-0.001 \pm 0.000$ & -- & ND & $\mathrm{ND}$ \\
\hline Side face bow & 270 & \pm 0.001 & $0.000 \pm 0.000$ & - & $\mathrm{ND}$ & $\mathrm{ND}$ \\
\hline
\end{tabular}

\footnotetext{
(a) Comparison of robot and hot cell measurements for surveillance element S/N 1-0743.

(b) Comparison of robot and Quality Control measurements on calibration element S/N 8-0182.

(c) BIAS = PIE - Robot.

(d) BIAS = QC - Robot.

(e) Undertainty on bias is less than \pm 0.005 .

(f) $N D=$ not determined.
} 
TABLE 6-15

APPARENT BOW IN BLOCK RESULTING FROM BOW IN ROBOT STRUCTURE

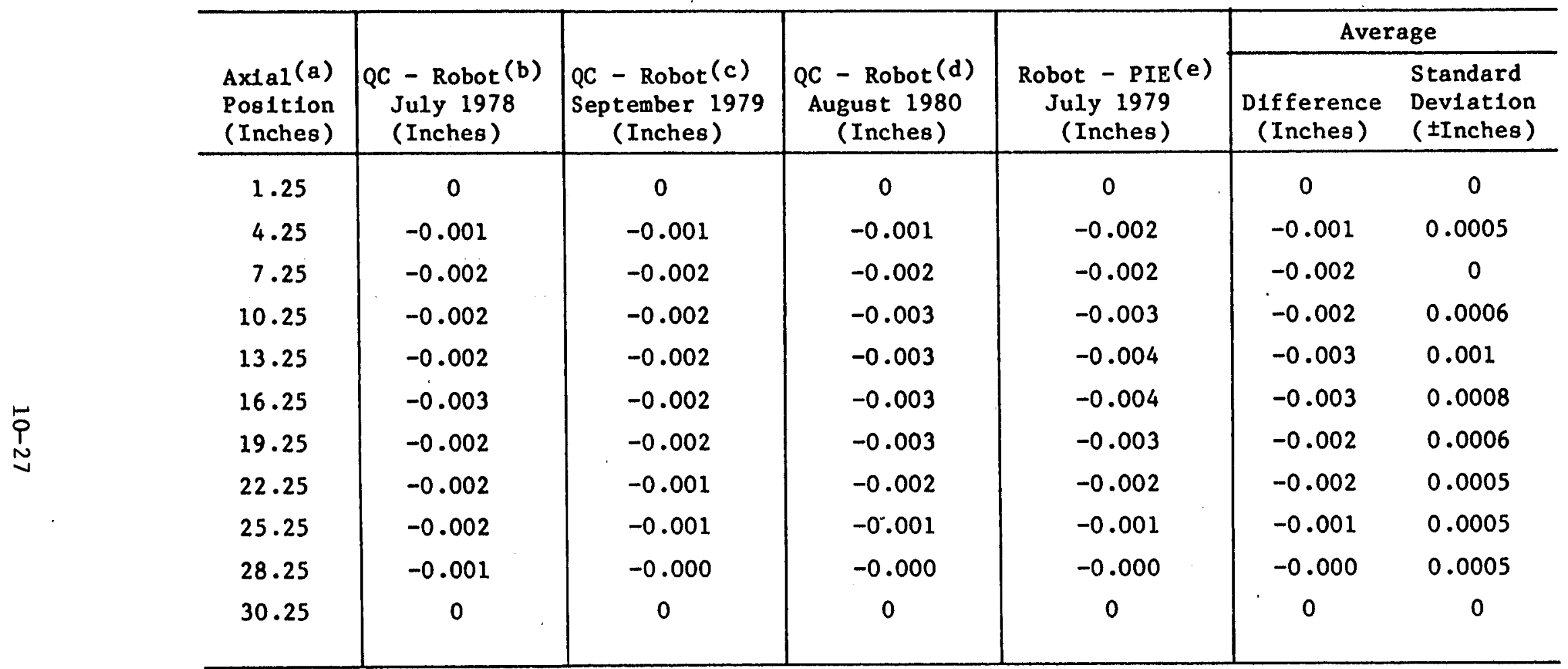

(a) Distance relative to bottom of fuel element.

(b) Robot measurements represent average values for two complete inspections of all six side faces of callbration element 8-0182.

(c) Robot measurements represent average values for five complete inspections of all $\mathrm{six}$ side faces of callbration element 8-0182.

(d) Robot measurements represent average values for four inspections of all six side faces of calibration element 8-0182, one column of measurements per face per inspection.

(e) Robot measurements performed in HSF at FSV during July 1979. 
TABLE 6-16

DISPLACEMENT OF SIDE FACES AT TOP OF BLOCK RELATIVE TO SIDE FACES AT BOTTOM OF BLOCK

\begin{tabular}{|c|c|c|c|c|c|c|}
\hline \multirow[b]{2}{*}{ Face } & \multirow[b]{2}{*}{$\begin{array}{c}Q C-\text { Robot (a) } \\
\text { July } 1978 \\
\text { (Inches) }\end{array}$} & \multirow[b]{2}{*}{$\begin{array}{l}\mathrm{QC}-\text { Robot }(\mathrm{b}) \\
\text { September } 1979 \\
\text { (Inches) }\end{array}$} & \multirow[b]{2}{*}{$\begin{array}{l}Q C-\text { Robot }(c) \\
\text { August } 1980 \\
\text { (Inches) }\end{array}$} & \multirow[b]{2}{*}{$\begin{array}{c}\text { PIE - Robot } \\
\text { July } 1979 \\
\text { (Inches) }\end{array}$} & \multicolumn{2}{|c|}{ Average } \\
\hline & & & & & $\begin{array}{c}\text { Difference } \\
\text { (Inches) }\end{array}$ & ( \pm Inches $)$ \\
\hline A & $0.003(e)$ & 0.016 & 0.028 & 0.012 & 0.015 & 0.010 \\
\hline B & .0 .004 & 0.016 & 0.012 & 0.013 & 0.011 & 0.005 \\
\hline C & 0.003 & 0.005 & 0.008 & 0.001 & 0.004 & 0.003 \\
\hline $\mathrm{D}$ & 0.014 & 0.011 & 0.025 & 0.004 & 0.013 & 0.009 \\
\hline E & 0.013 & 0.013 & 0.032 & 0.000 & 0.014 & 0.013 \\
\hline F & 0.006 & 0.020 & 0.031 & 0.008 & 0.016 & 0.012 \\
\hline
\end{tabular}

(a) Robot measurements represent average values for two complete inspections of all six side faces of calibration element 8-0182.

(b) Robot measurements represent average values for five complete inspections of all six side faces of calibration element 8-0182.

(c) Robot measurements represent average values for four inspections of all six side faces of calibration element 8-0182, one column of measurements per face per inspection.

(d) Robot measurements performed in hot service facility at FSV during July 1979.

(e) Positive displacement indicates the element is tilted toward the robot structure. 
TABLE 7-1 LOCATIONS OF STAINS OBSERVED DURING SURVEILLANCE OF CORE SEGMENT 1 (a)

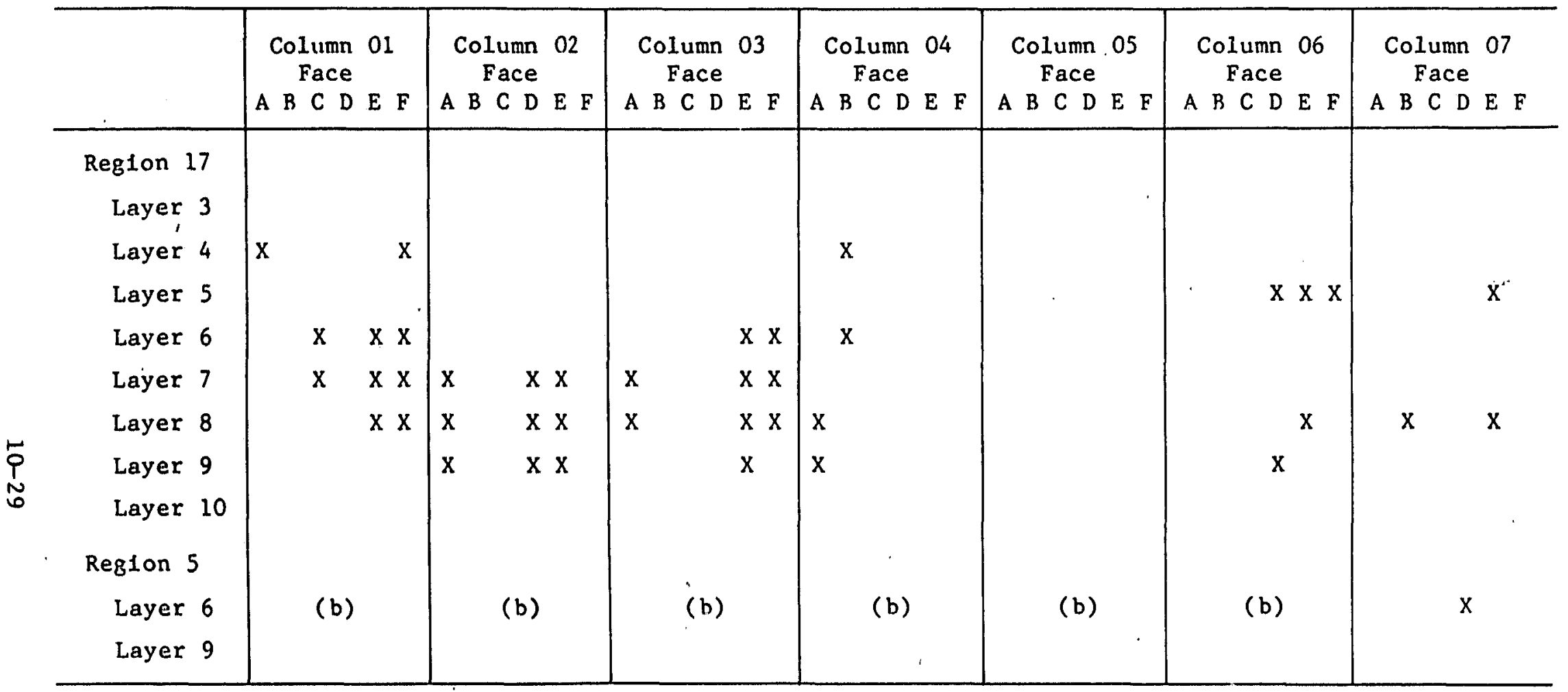

(a) Inspected elements 40 through 51 not included.

(b) Not inspected. 
TABLE 7-2

LOCATIONS OF RUB MARKS OBSERVED DURING SURVEILLANCE OF CORE SEGMENT 1 (a)

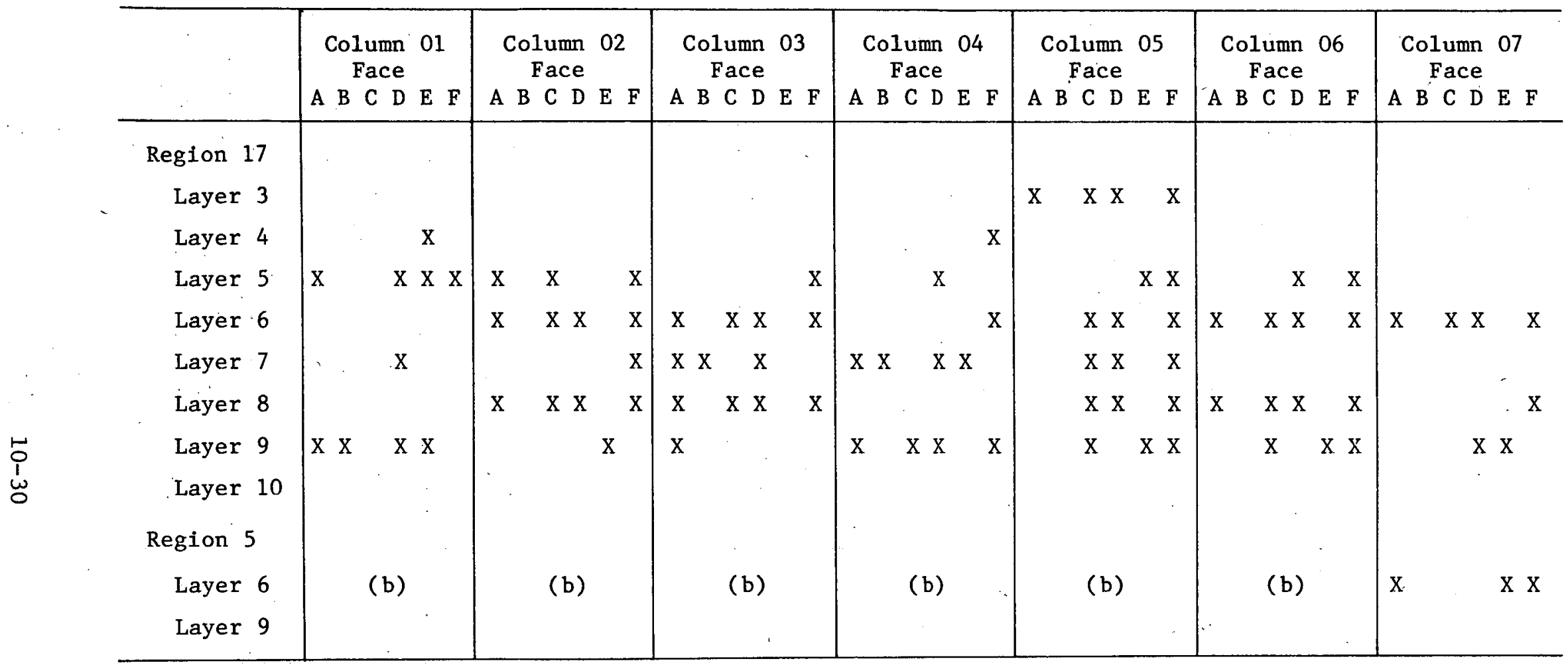

(a) Inspected elements 40 through 51 not included.

(b) Not inspected. 
TABLE 7-3

LOCATIONS OF INTERFACE MARKS OBSERVED DURING SURVEILLANCE OF CORE SEGMENT 1 (a)

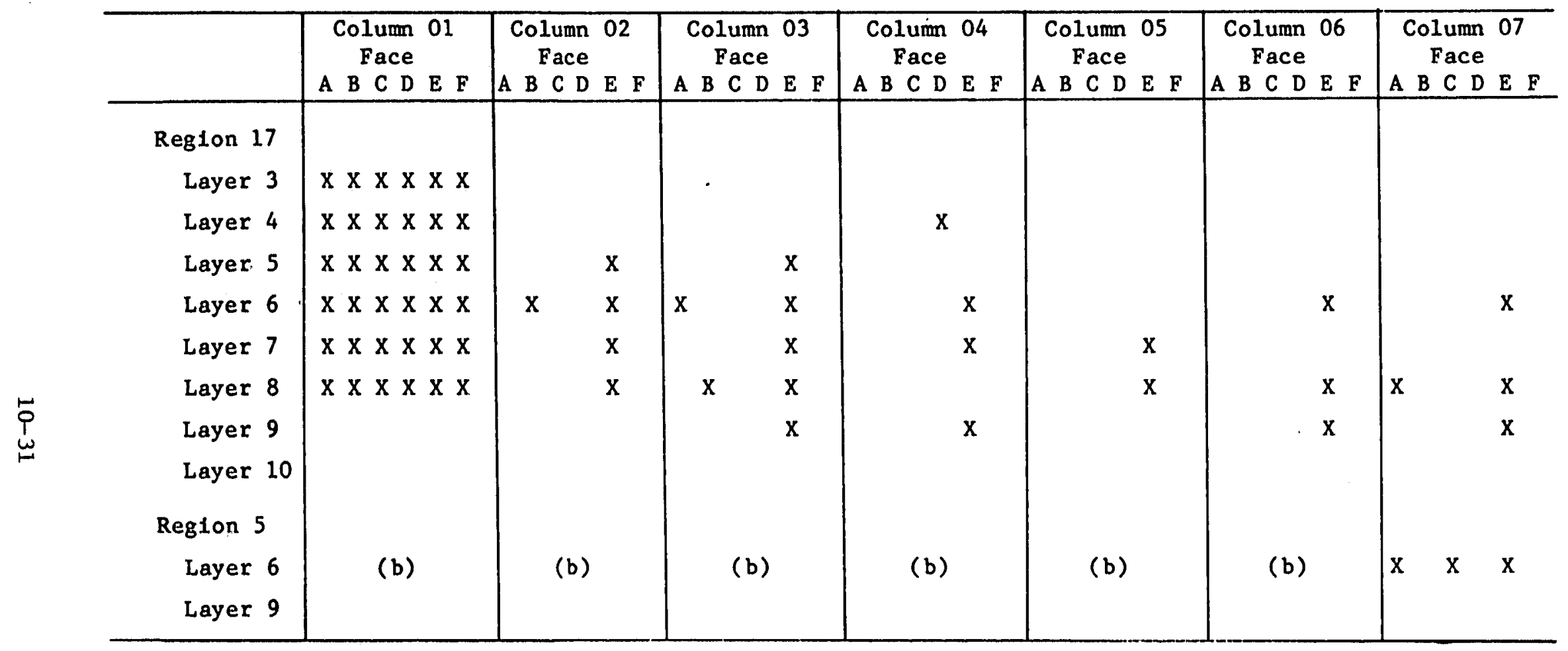

(a) Inspected elements 40 through 51 not Included.

(b) Not inspected. 


\section{FIGURES}

2-1. Metrology robot in HSF at FSV.

2-2. Front view of metrology robot probe; $Z$ probe in contact with top surface of fuel block.

2-3. Metrology robot coordinate system.

2-4. Metrology robot data acquisition and control system.

3-1. Chord measurements.

3-2. Side face measurements.

3-3. Top surface measurements.

(a) Regular fuel element.

(b) Control-rod fuel element.

3-4. Coolant hole measurements.

3-5. Fiducial hole measurements.

4-1. Determination of average radiation level for inspected fuel elements.

4-2. Dose rate versus distance from spent fuel block surface.

5-1. Envelope of axial strains observed in FSV segment 1 fuel elements.

5-2. Envelope of radial strains observed in FSV segment 1 fuel elements. 
5-3. Axial strain distribution and side face bow in FSV core region 17.

(a) Axial leve1 4 .

(b) Axial level 5 .

(c) Axial level 6 .

(d) Axial level 7 .

(e) Axial leve1 8 .

(f) Axial level 9 .

5-4. Differences in measured and calculated axial strain for FSV segment 1 fuel elements.

5-5. Differences in measured and calculated radial strain for FSV segment 1 fuel elements.

5-6. Calculated bow versus measured bow for FSV segment 1 fuel elements.

5-7. Comparison of axial strains observed in FSV segment 1 fuel elements with the design curves for irradiation-induced dimensional change of $\mathrm{H}-327$ graphite in the axial orientation.

7-1. Dark stain on side face D of element 17.02.F.08. (Mosaic 1 of 4).

7-2. Dark stain on side face D of element 17.02.F.08. (Mosaic 2 of 4).

7-3. Dark stain on side face D of element 17.02.F.08. (Mosaic 3 of 4).

7-4. Dark stain on side face D of element 17.02.F.08. (Mosaic 4 of 4).

7-5. Rub marks on face F of element 17.04.F.09.

7-6. Interface mark on side face A of element 17.01.F.07.

7-7. Soot deposits on bottom side face $\mathrm{E}$ of element 17.03.F.05. 
7-8. Scratch on side face $\mathrm{C}$ of element 17.06.F.05. (Mosaic 1 of 4).

7-9. Scratch on side face C of element 17.06.F.05. (Mosaic 2 of 4).

7-10. Scratch on side face $C$ of element 17.06.F.05. (Mosaic 3 of 4).

7-11. Scratch on side face C of element 17.06.F.05. (Mosaic 4 of 4).

7-12. Fingerprints on bottom side face B of element 17.01.F.07.

7-13. Large chip on bottom chamfer of side face $\mathrm{F}$ of element 17.04.F.06.

7-14. Debris on dowel of element 17.04.F.07.

7-15. Circle around fuel handling hole on top surface of element $17.07 . \mathrm{F} .07$.

7-16. Painted $\mathrm{H}$ on top surface of element 17.02.F.06. 


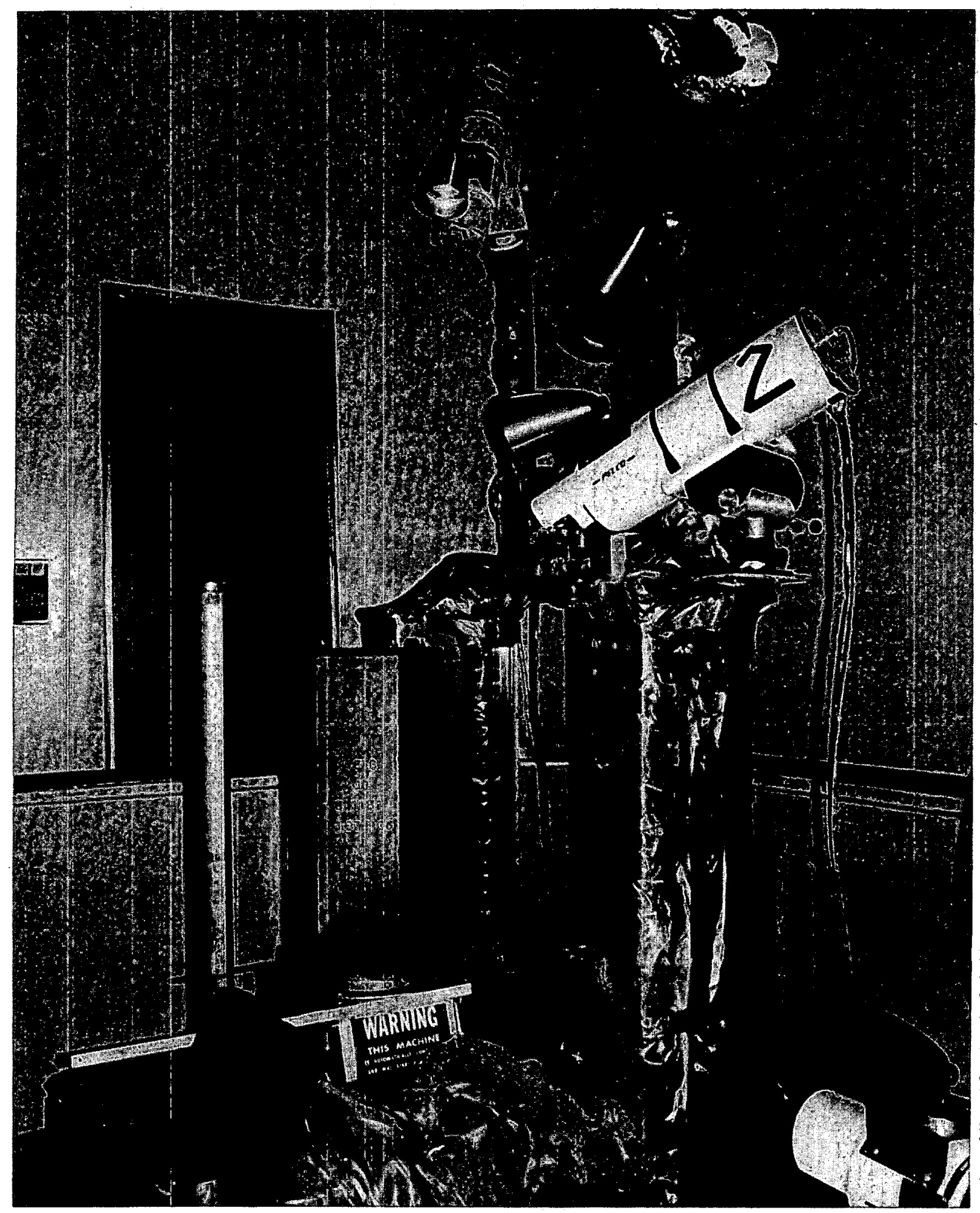

Fig. 2-1. Metrology robot in HSF at FSV 


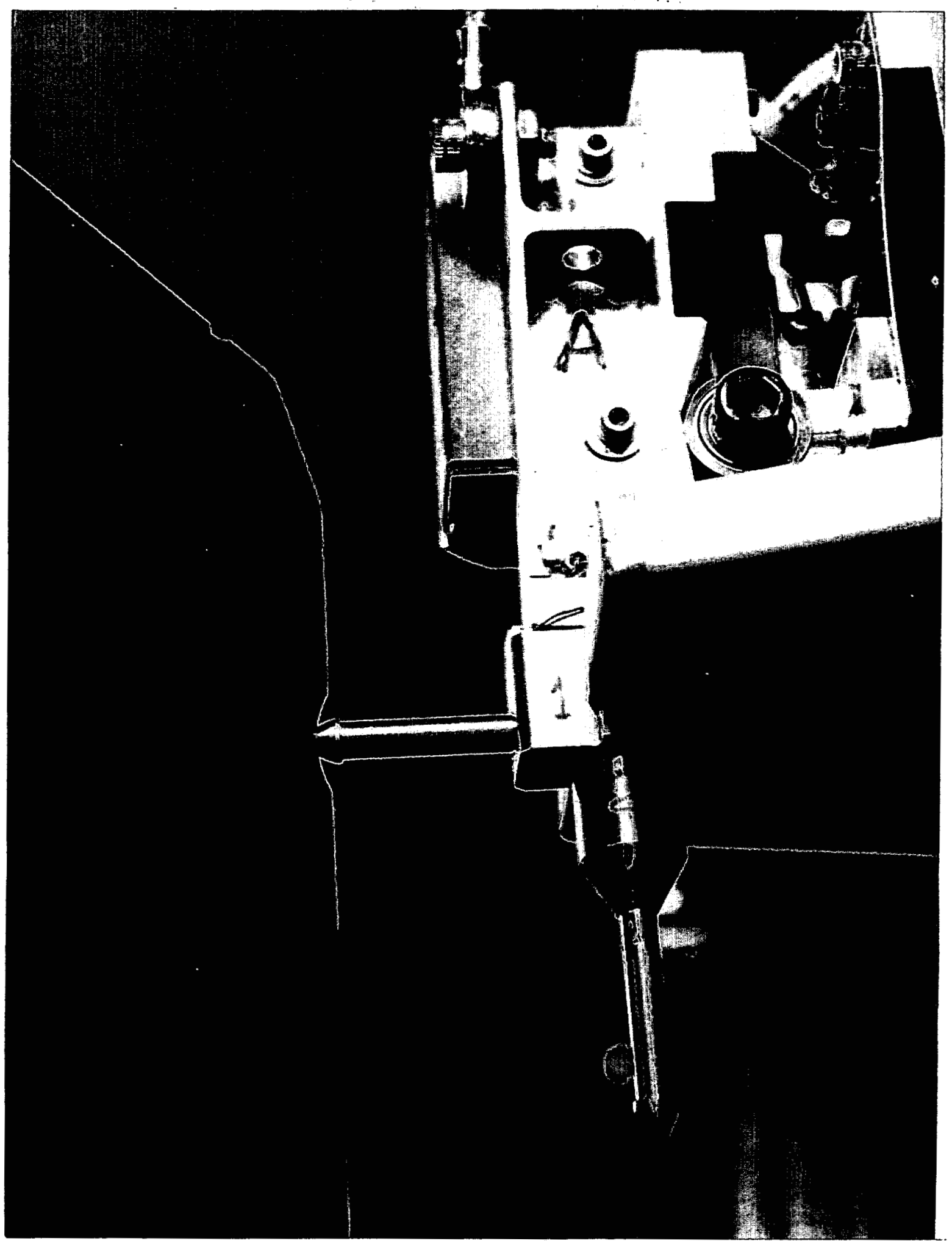

Fig. 2-2. Front view of metrology robot probe; $z$ probe 1 eg in contact with top surface of fuel block 


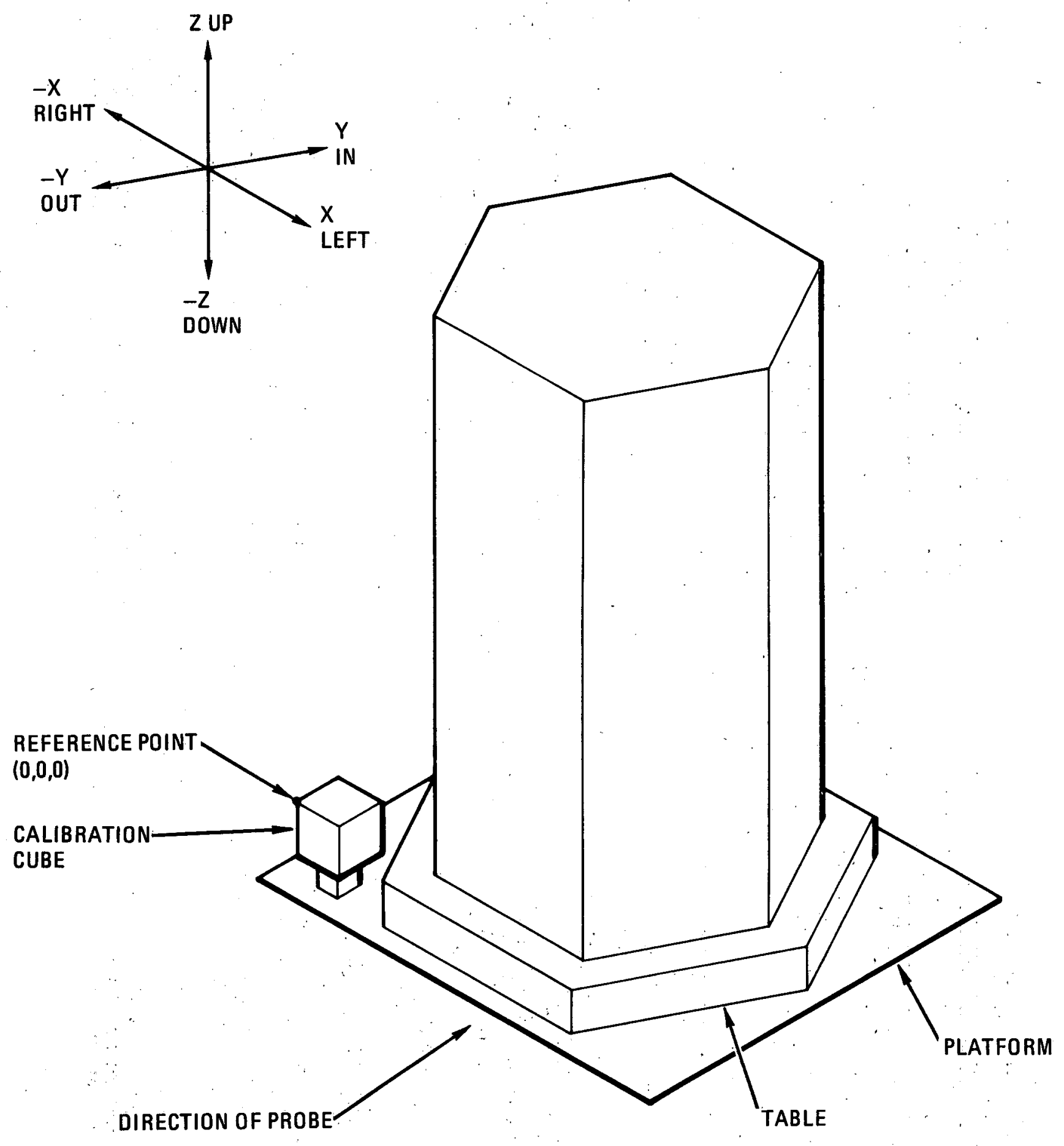

Fig. 2-3. Metrology robot coordinate system 


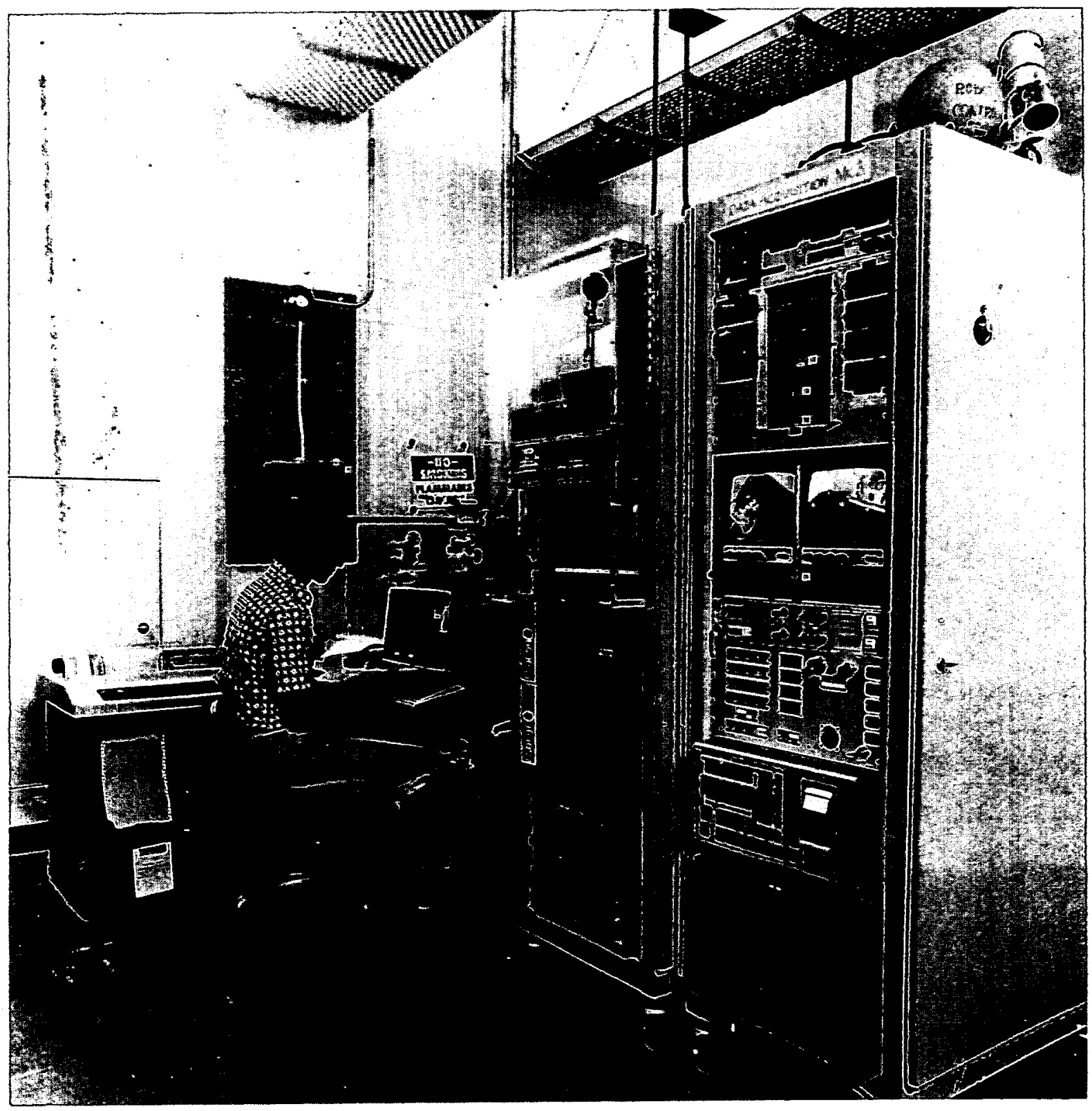

Fig. 2-4. Metrology robot data acquisition and control system. 


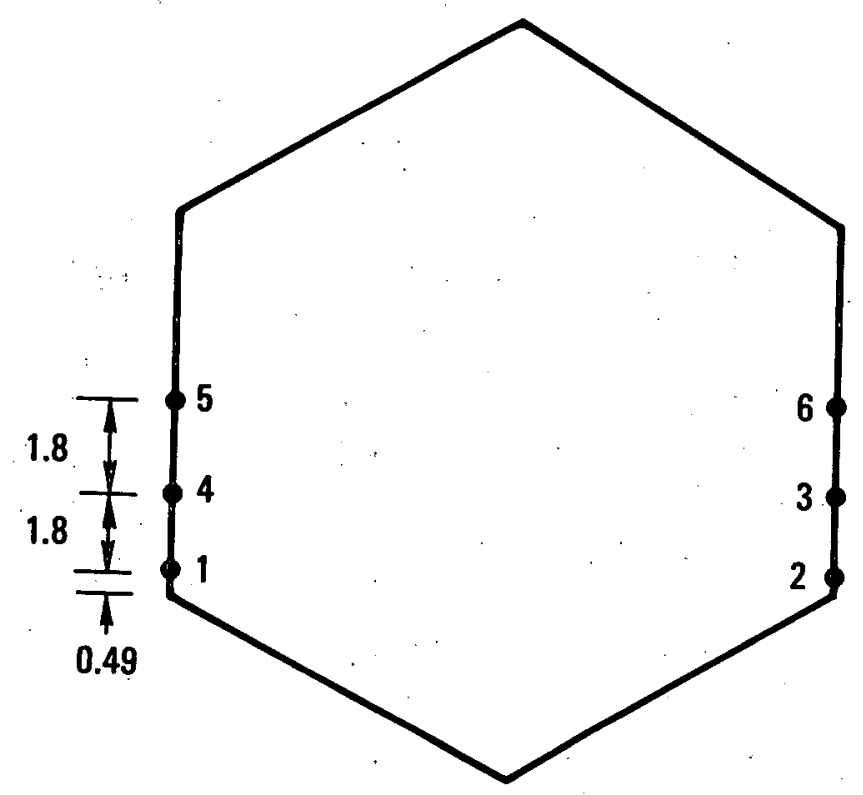

MEASUREMENTS (POINTS) 1 THROUGH 6 REPEATED WITH EACH CORNER

OF THE ELEMENT FACING THE PROBE.

FULL-LENGTH INSPECTION

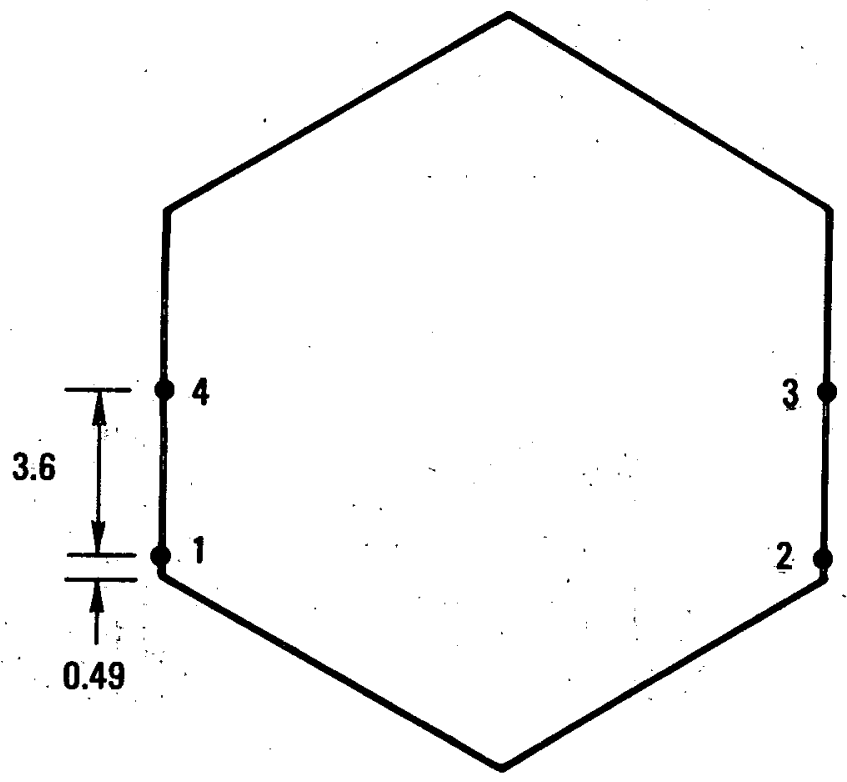

MEASUREMENTS (POINTS) 1 THROUGH 4 REPEATED WITH EACH CORNER OF

THE ELEMENT FACING THE PROBE.

(ALL DIMENSIONS IN INCHES)

\section{ABBREVIATED INSPECTION}

Fig. 3-1. Chord Measurements 


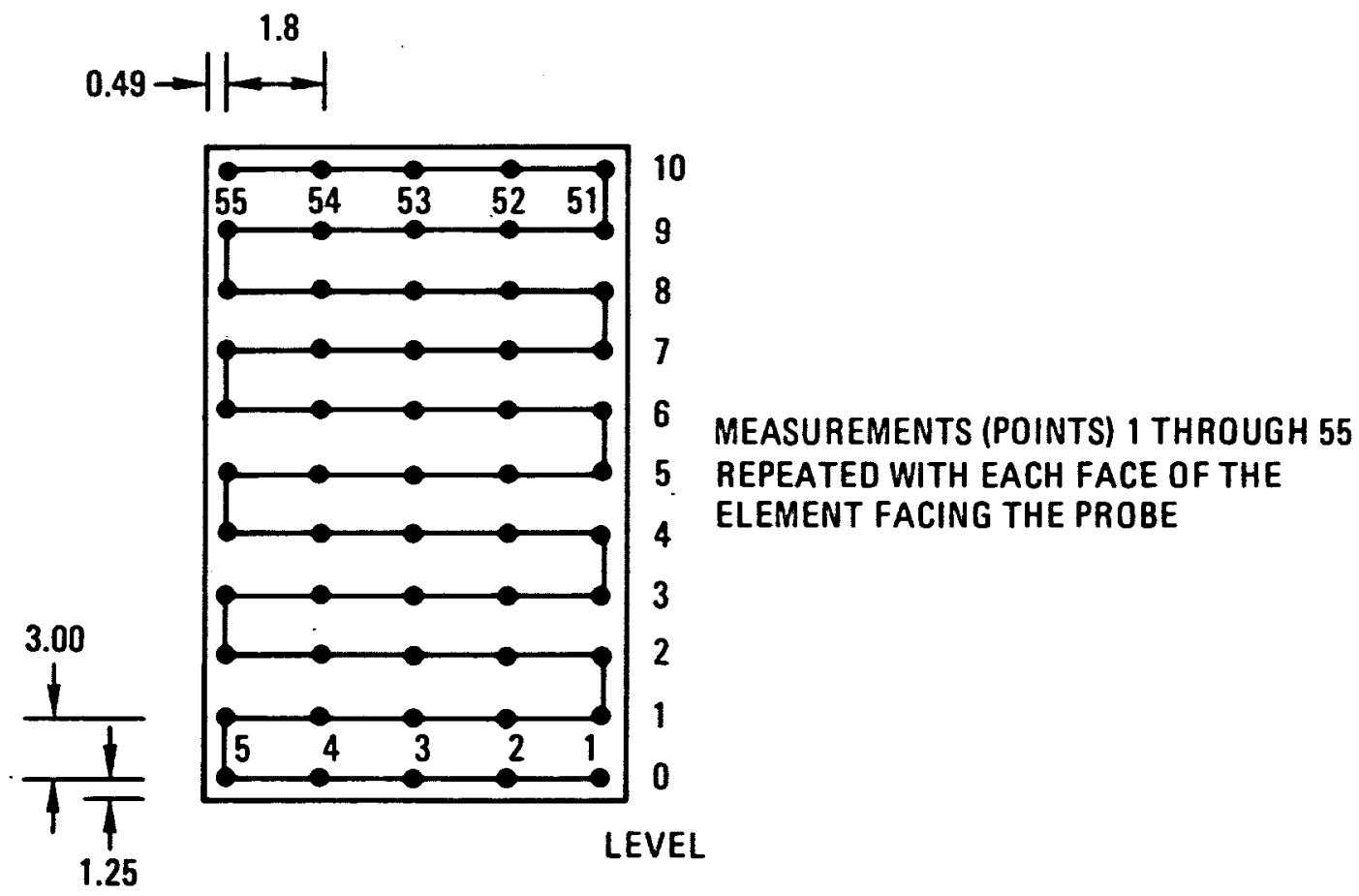

FULL-LENGTH INSPECTION

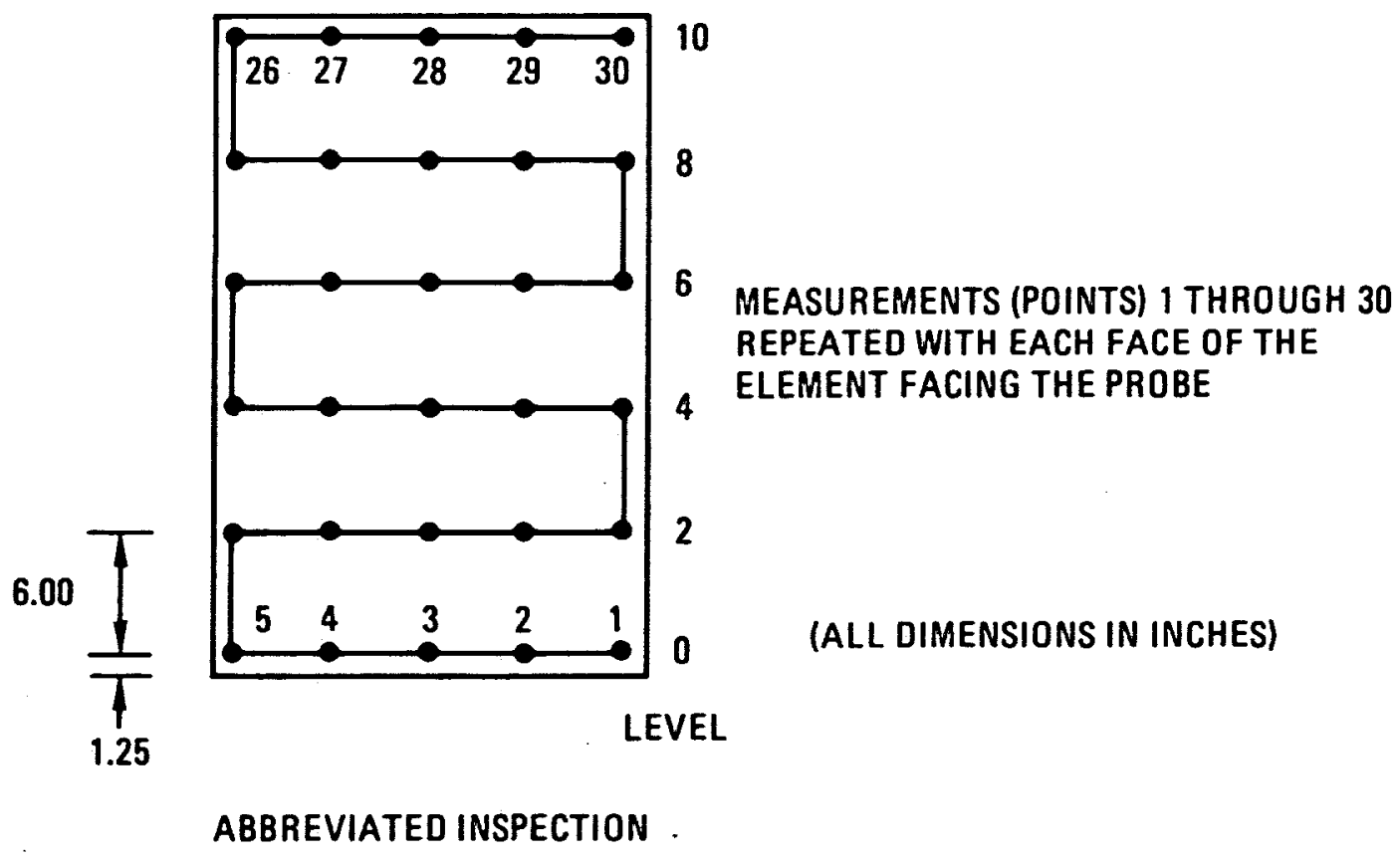

Fig. 3-2. Side face measurements 


\section{FACE E}

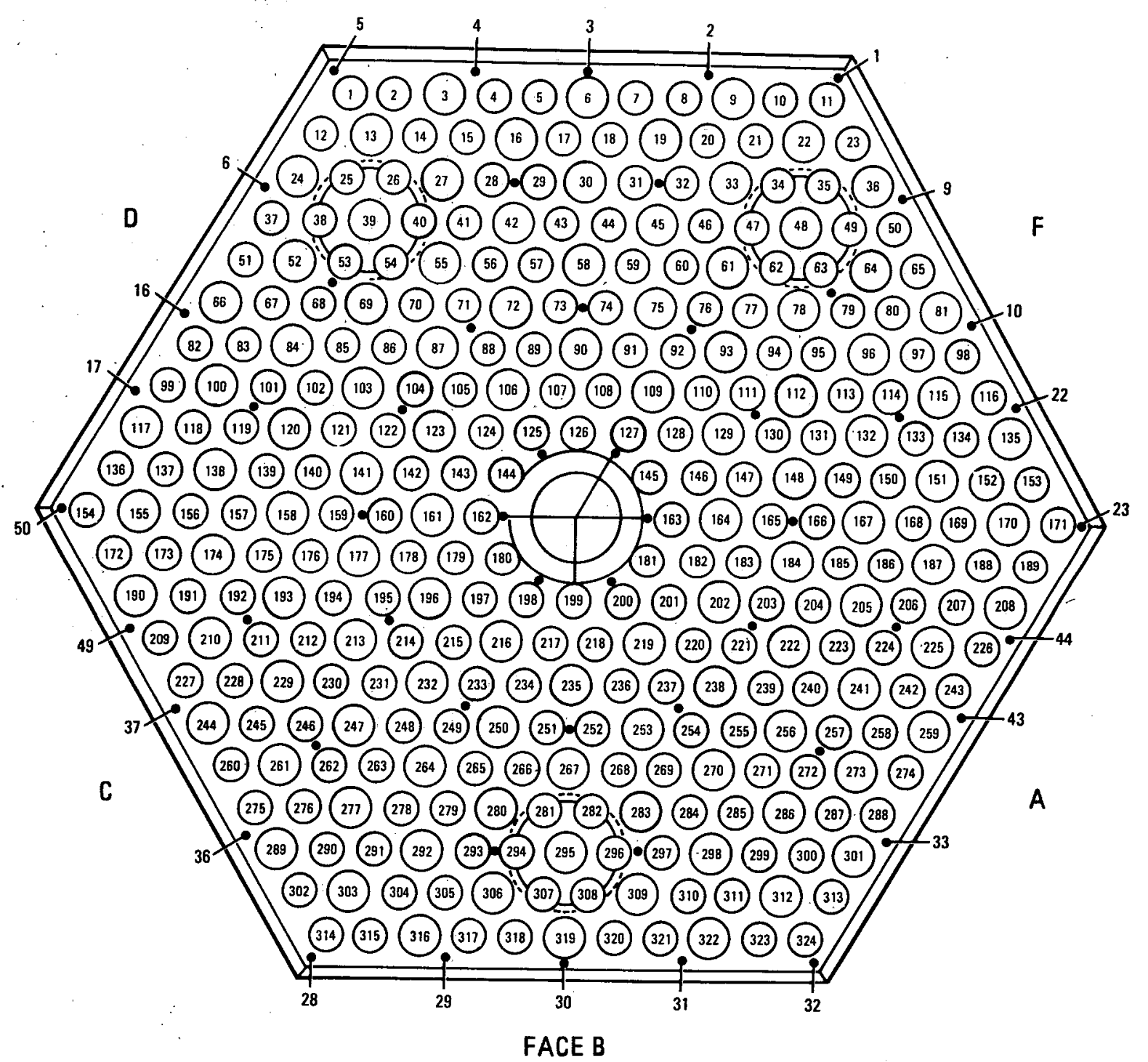

(a) REGULAR FUEL ELEMENT; FULL LENGTH

AND ABBREVIATED INSPECTIONS

Fig. 3-3. Top surface measurements (page 1 of 2) 


\section{FACE E}

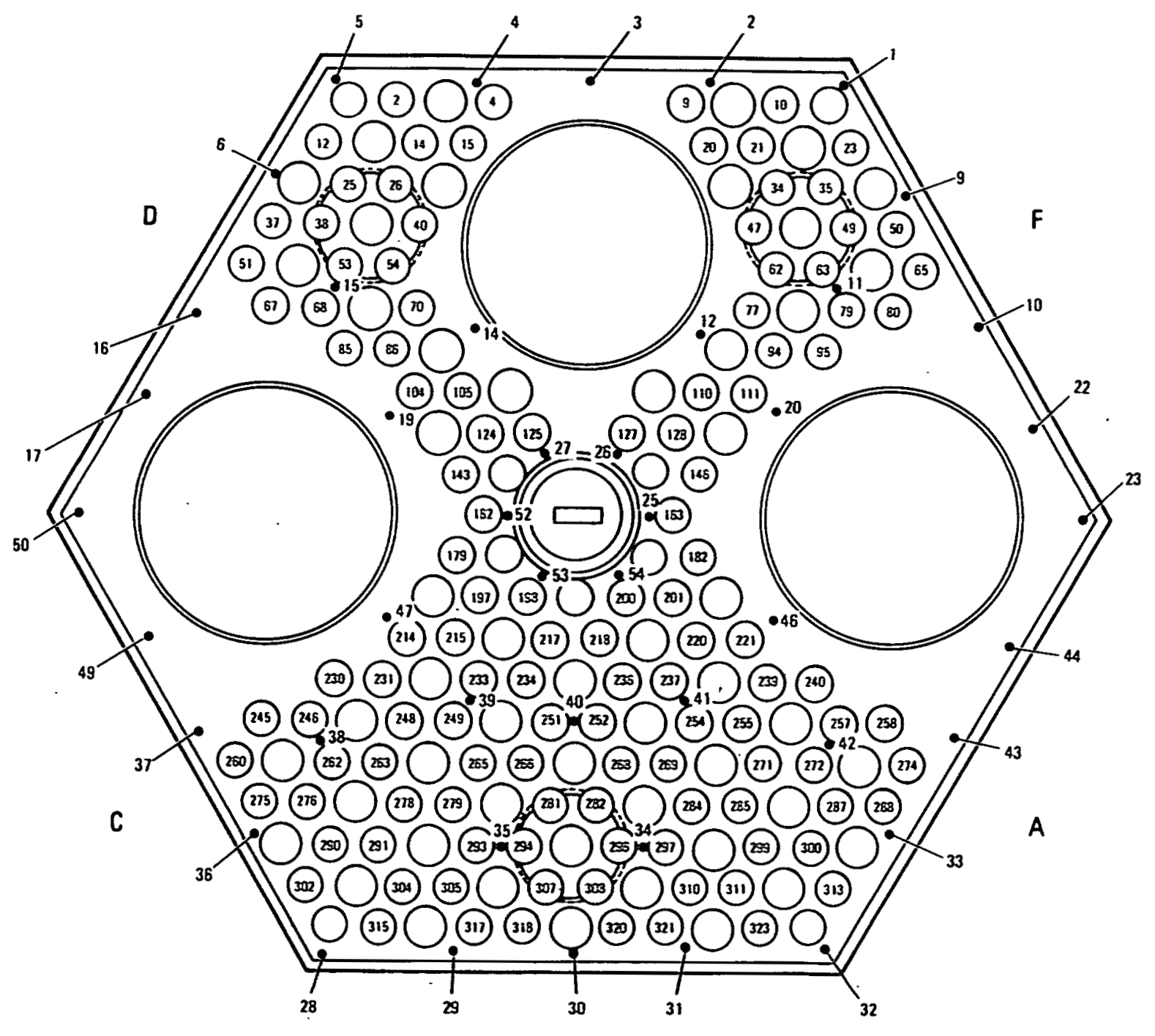

FACE B

(b) CONTROL-ROO FUEL ELEWENT; FULL-LENGTH AND ABBREVIATED INSPECTIOHS

Fig. 3-3. Top surface measurements (page 2 of 2) 


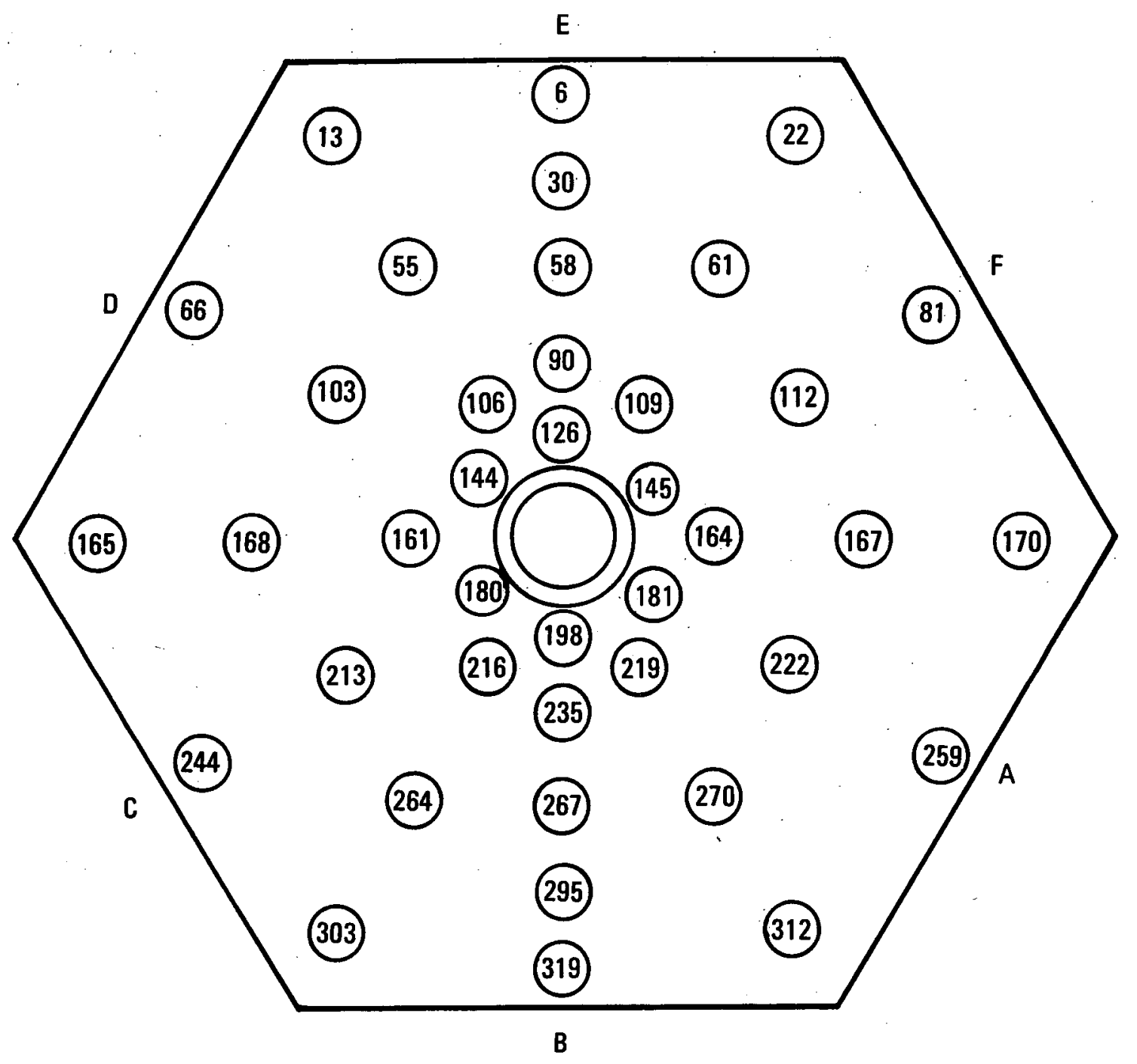

FULL LENGTH INSPECTION - REGULAR FUEL ELEMENT

NOTE: COOLANT HOLES 66, 81, 103, 112, 144, 145, 180, 181, 213, 222, 244, AND 259 OMITTED FOR ABBREVIATED INSPECTION OF REGULAR FUEL ELEMENT. COOLANT HOLES 312, 270, 219, 181, 199, 235, 180, 216, 264, 303, 319, 295, 267, 13, 106, 144, 145, 109, AND 22 MEASURED FOR CONTROL-ROD ELEMENTS.

Fig. 3-4. Coolant hole measurements 

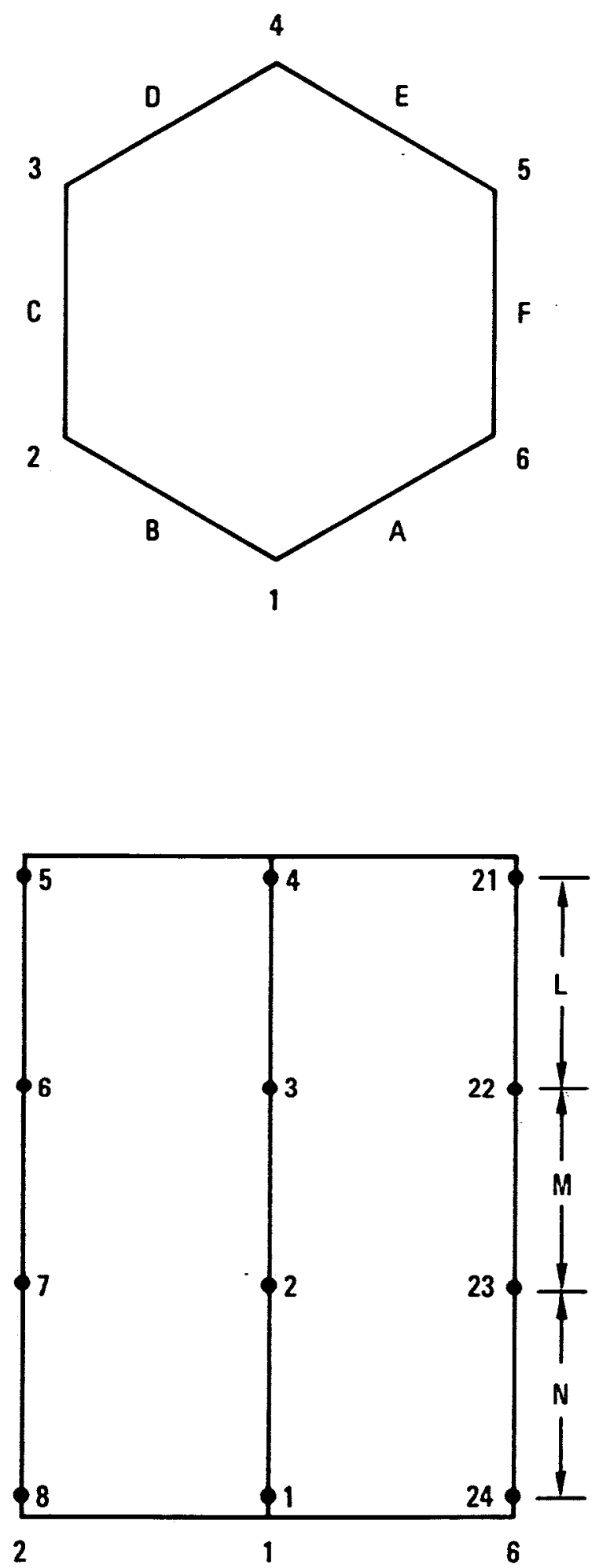

Fig. 3-5. Fiducial hole measurements

$11-13$ 



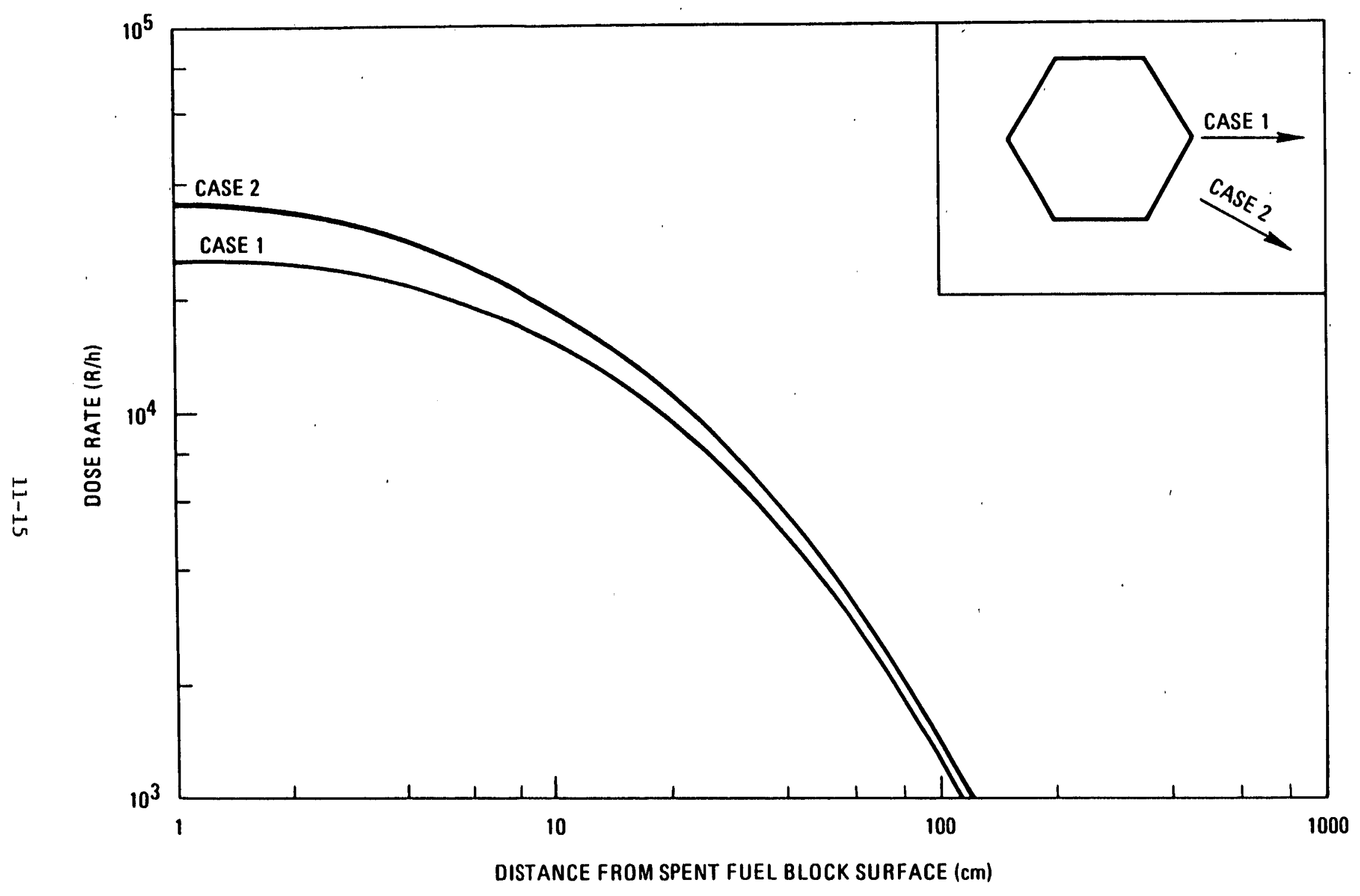

Fig. 4-2. Dose rate versus distance from spent fuel block surface 


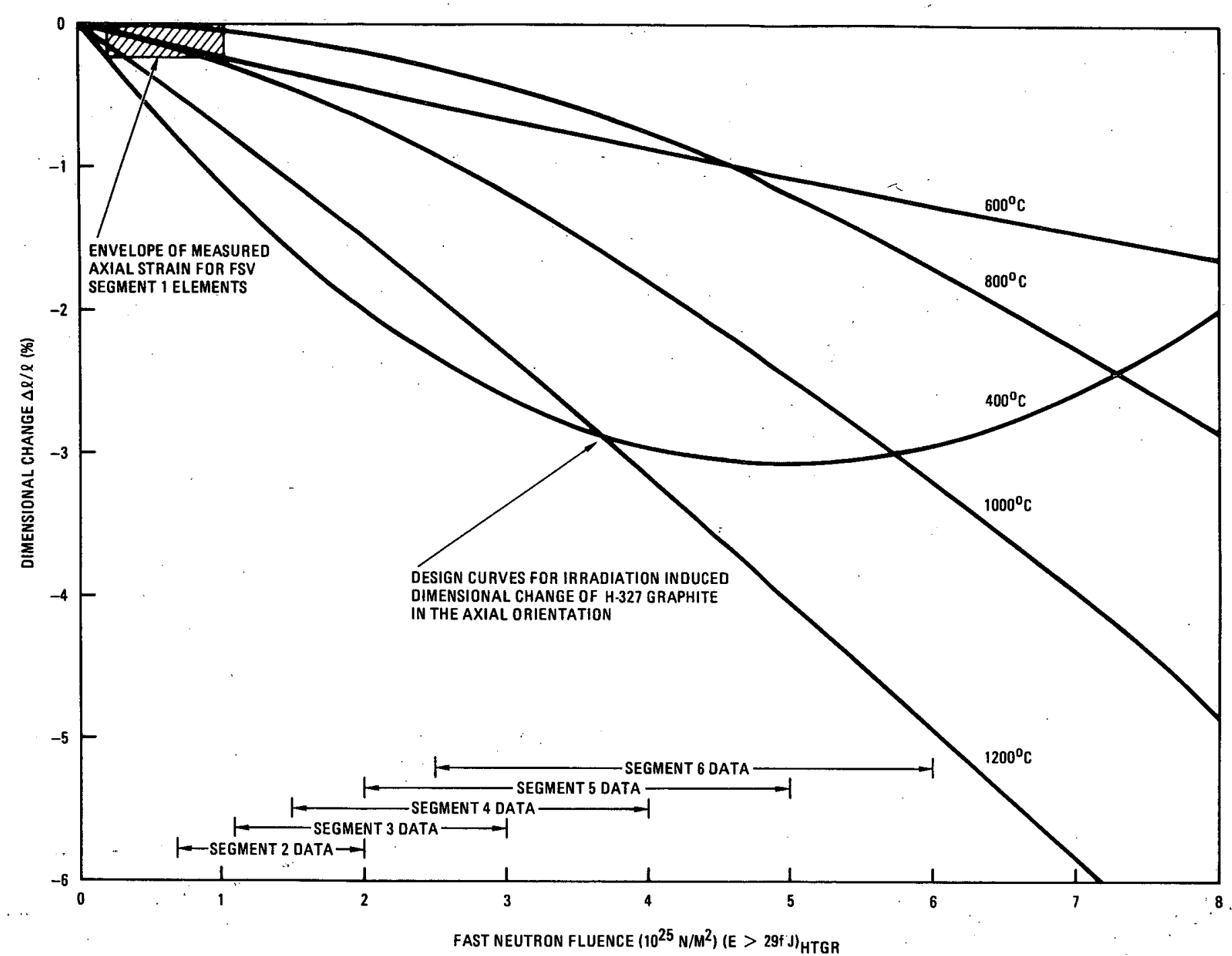

Fig. 5-1. Envelope of axial strains observed in FSV segment 1 fuel elements 


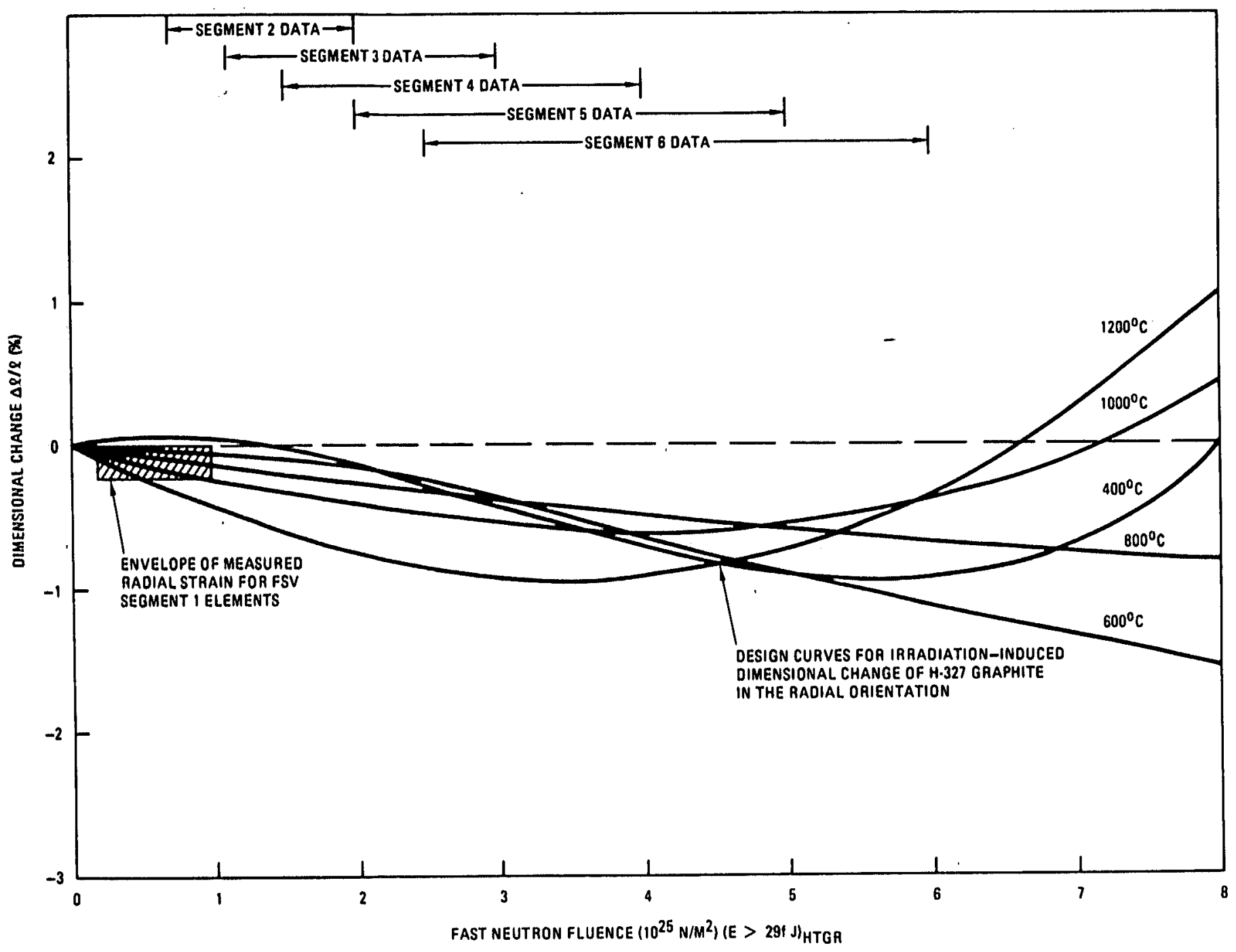

Fig. 5-2. Envelope of radial strains observed in FSV segment 1 fuel elements 


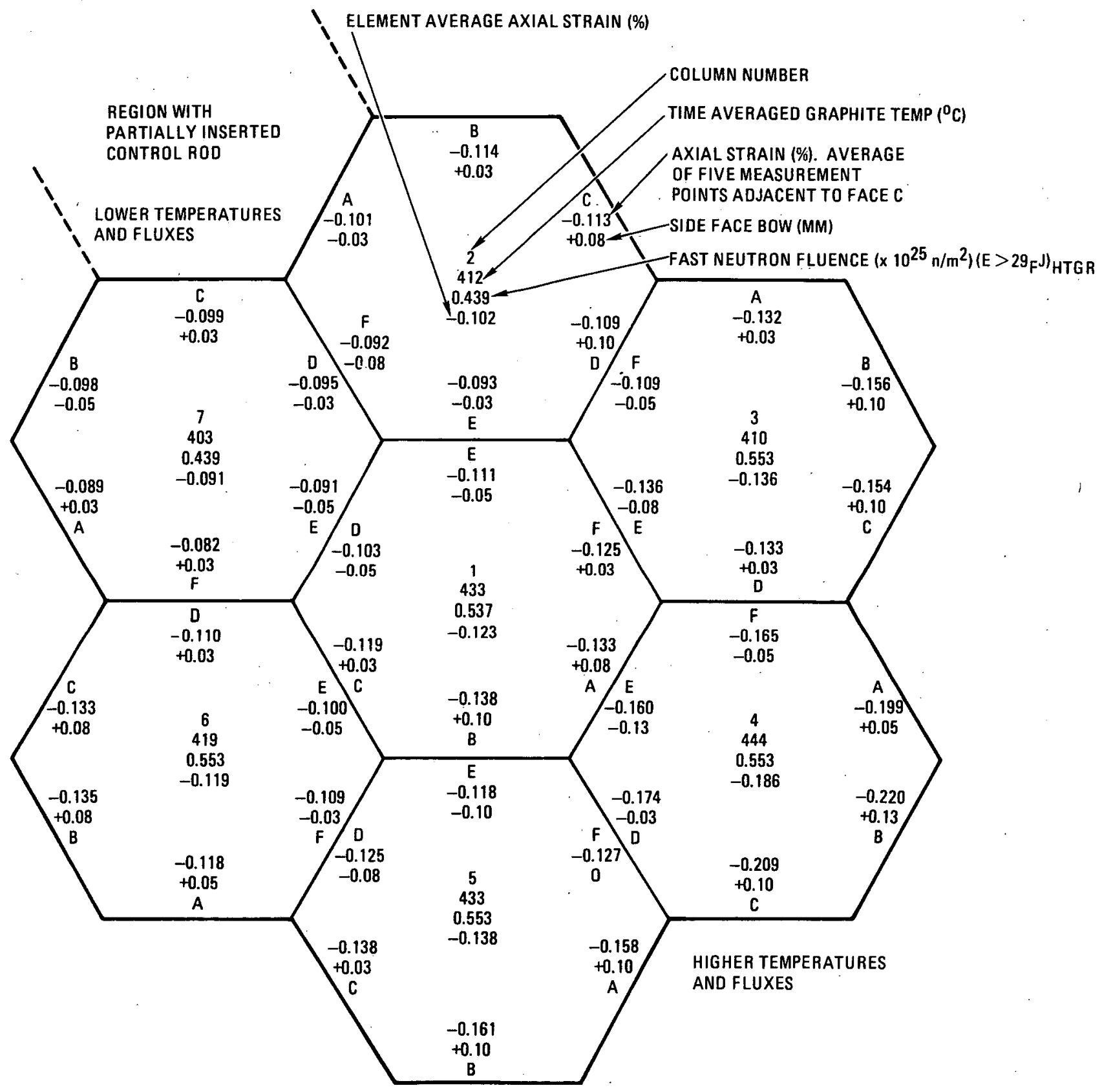

(a) AXIAL LEVEL 4

Fig. 5-3. Axial strain distribution and side face bow in FSV core region 17 (page 1 of 6 ) 


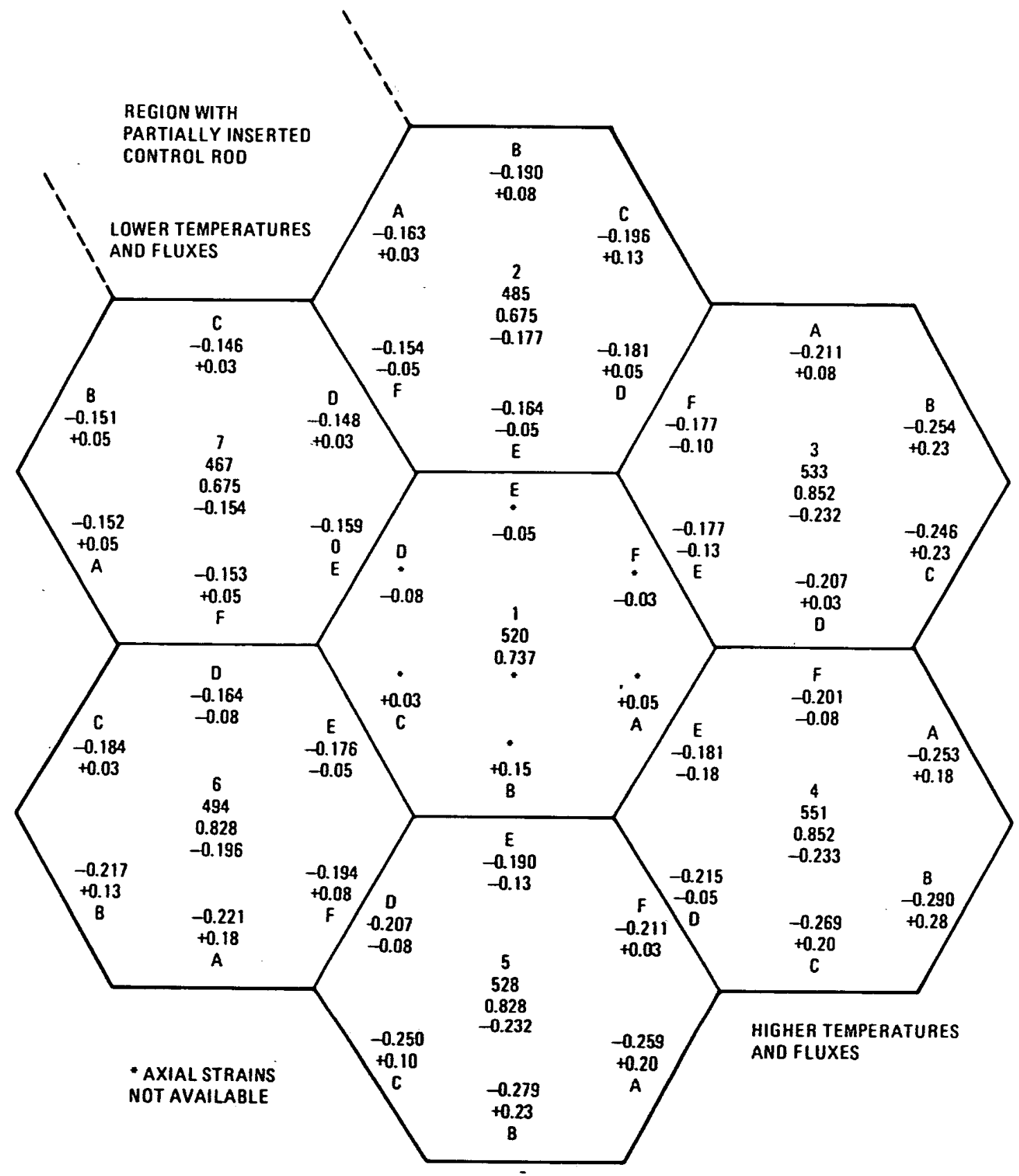

(b) AXIAL LEVEL 5

Fig. 5-3. Axial strain distribution and side face bow in FSV core region 17 (page 2 of 6 ) 


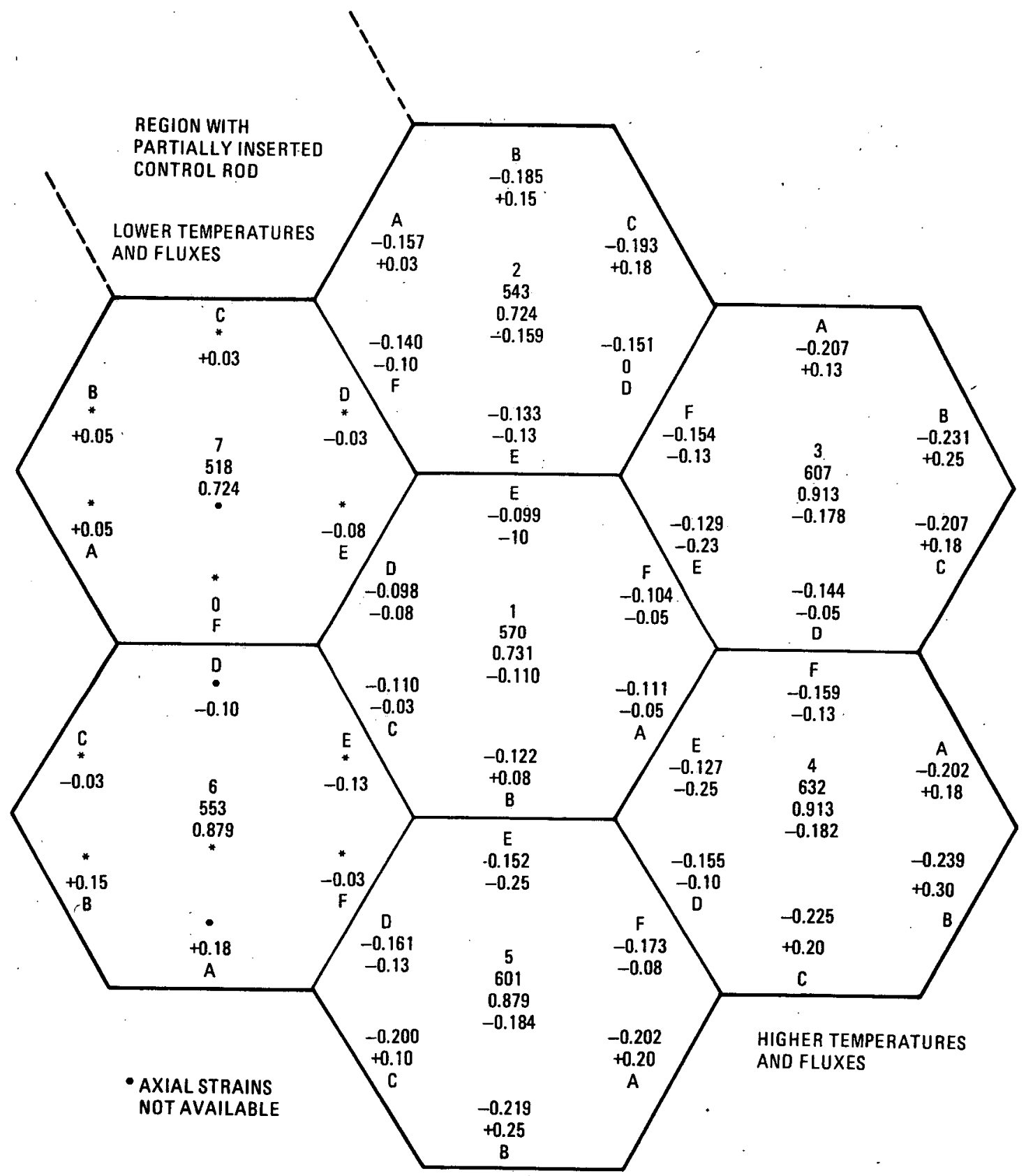

(c) AXIAL LEVEL 6

Fig. 5-3. Axial strain distribution and side face bow in FSV core region 17 (page 3 of 6 ) 

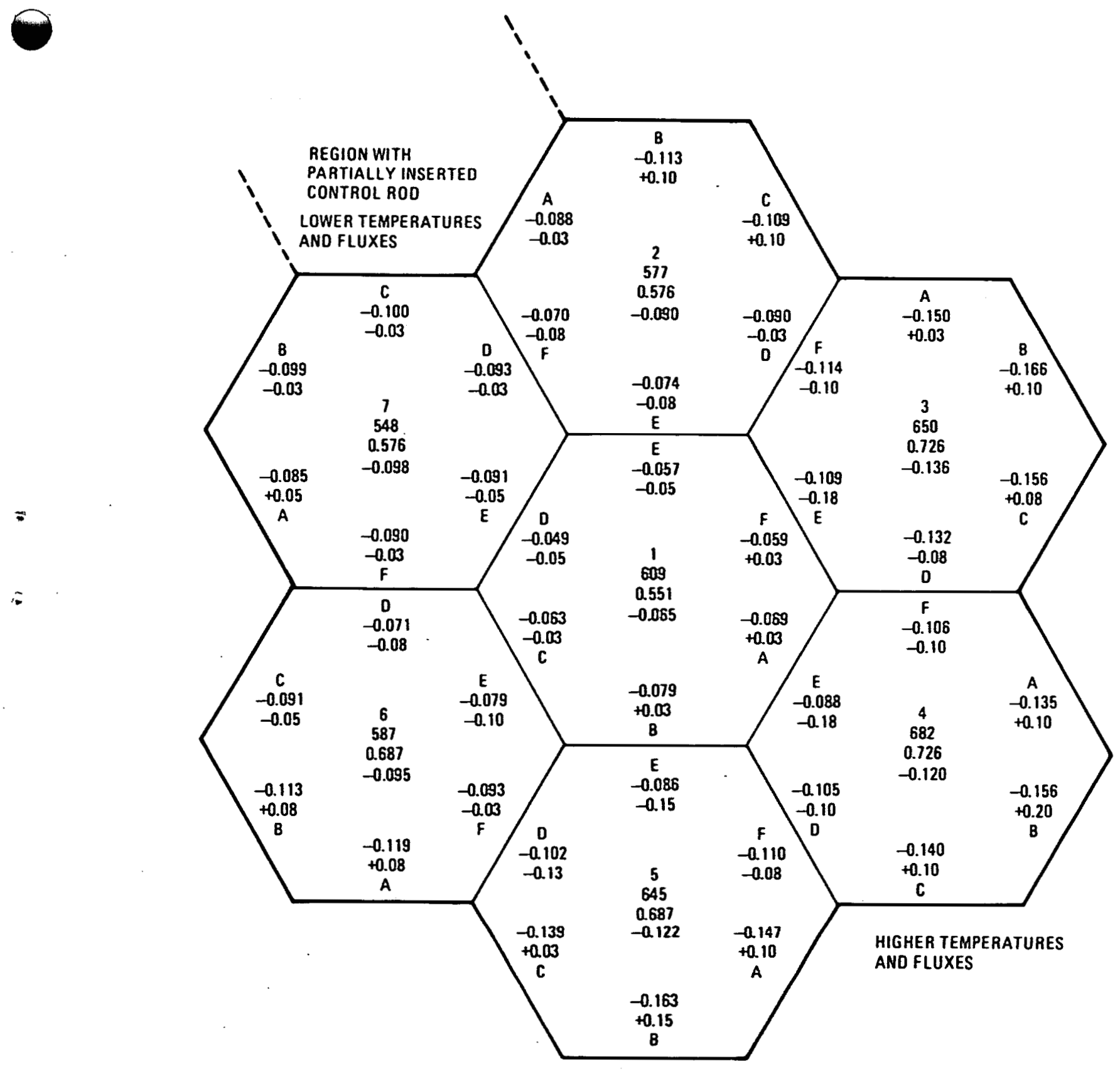

(d) AXIAL LEVEL 7

Fig. 5-3. Axial strain distribution and side face bow in FSV core region 17 (page 4 of 6) 


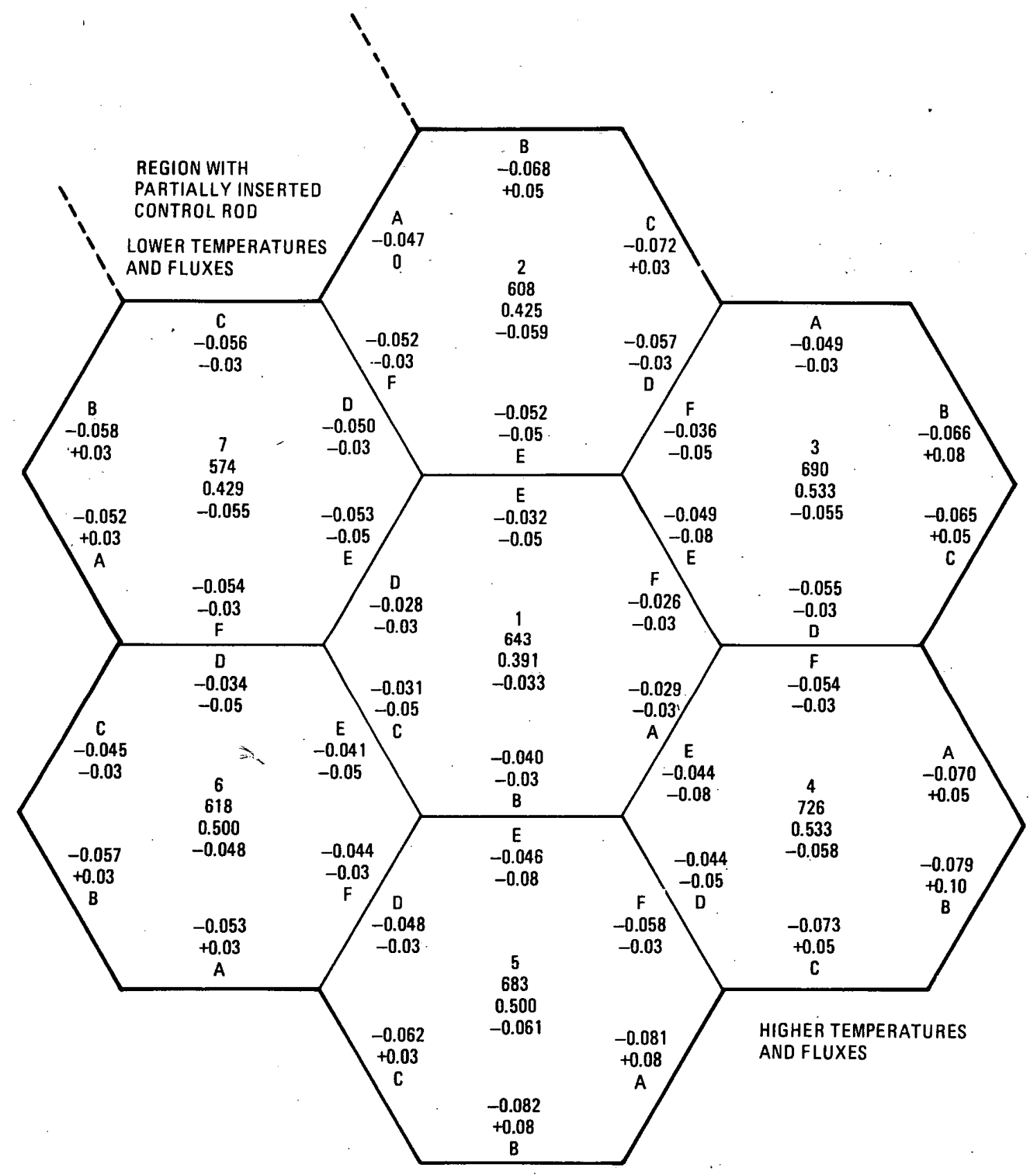

(e) AXIAL LEVEL 8

Fig. 5-3. Axial strain distribution and side face bow in FSV core region 17 (page 5 of 6 ) 


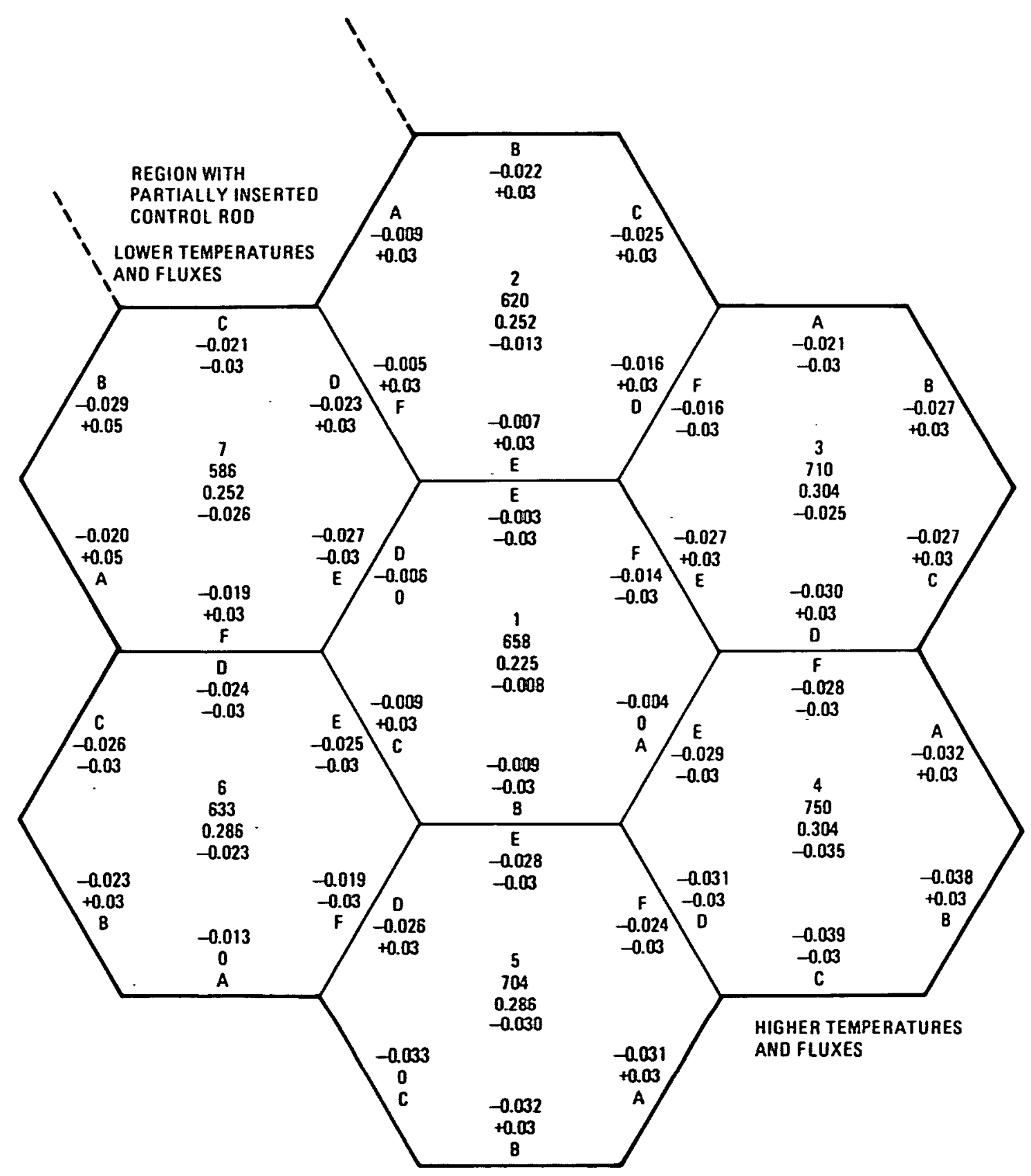

(i) AXIAL LEVEL 9

Fig. 5-3. Axial strain distribution and side face bow in FSV core region 17 (page 6 of 6 ) 


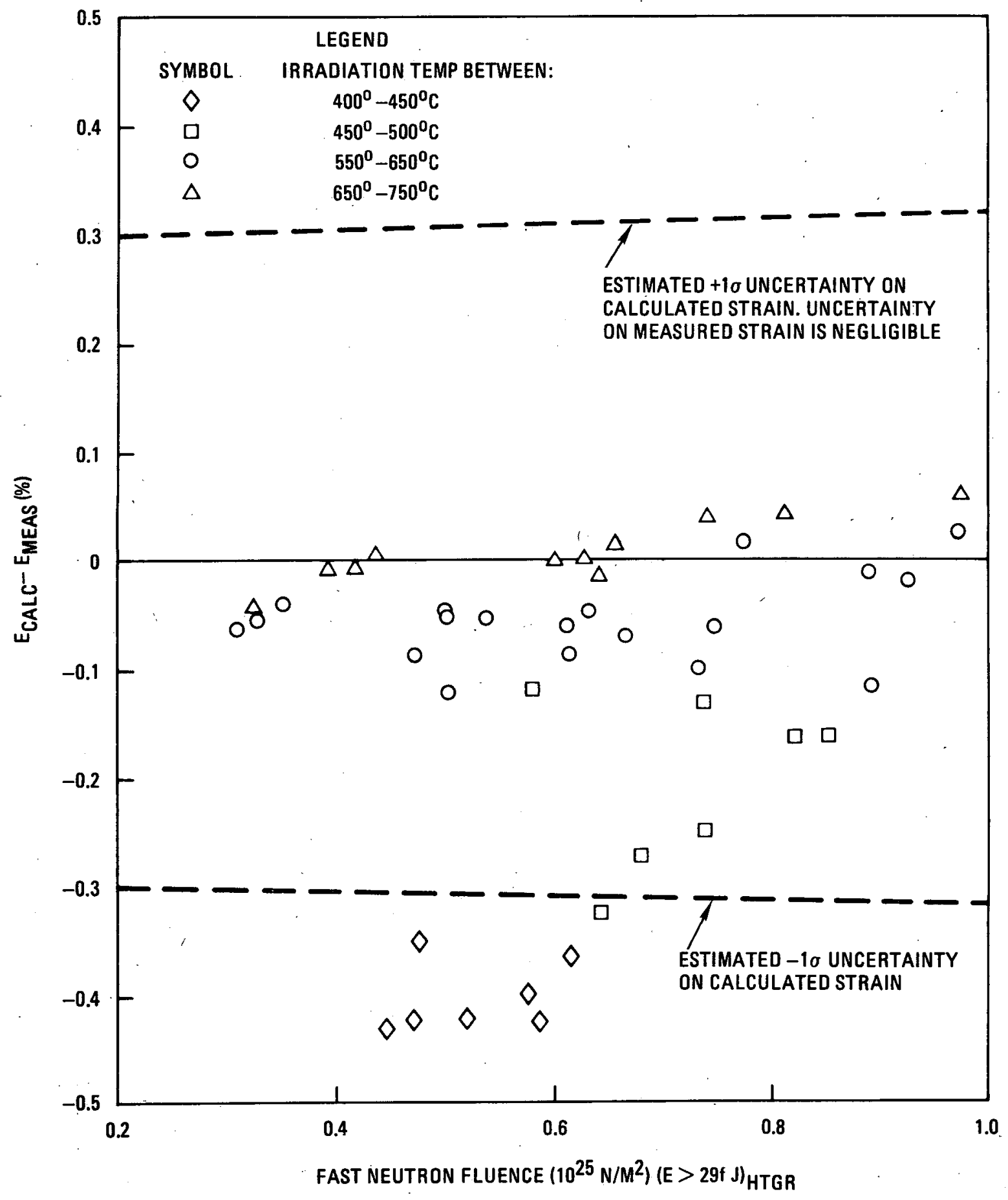

Fig. 5-4. Differences in measured and calculated axial strain for FSV segment 1 fuel elements 


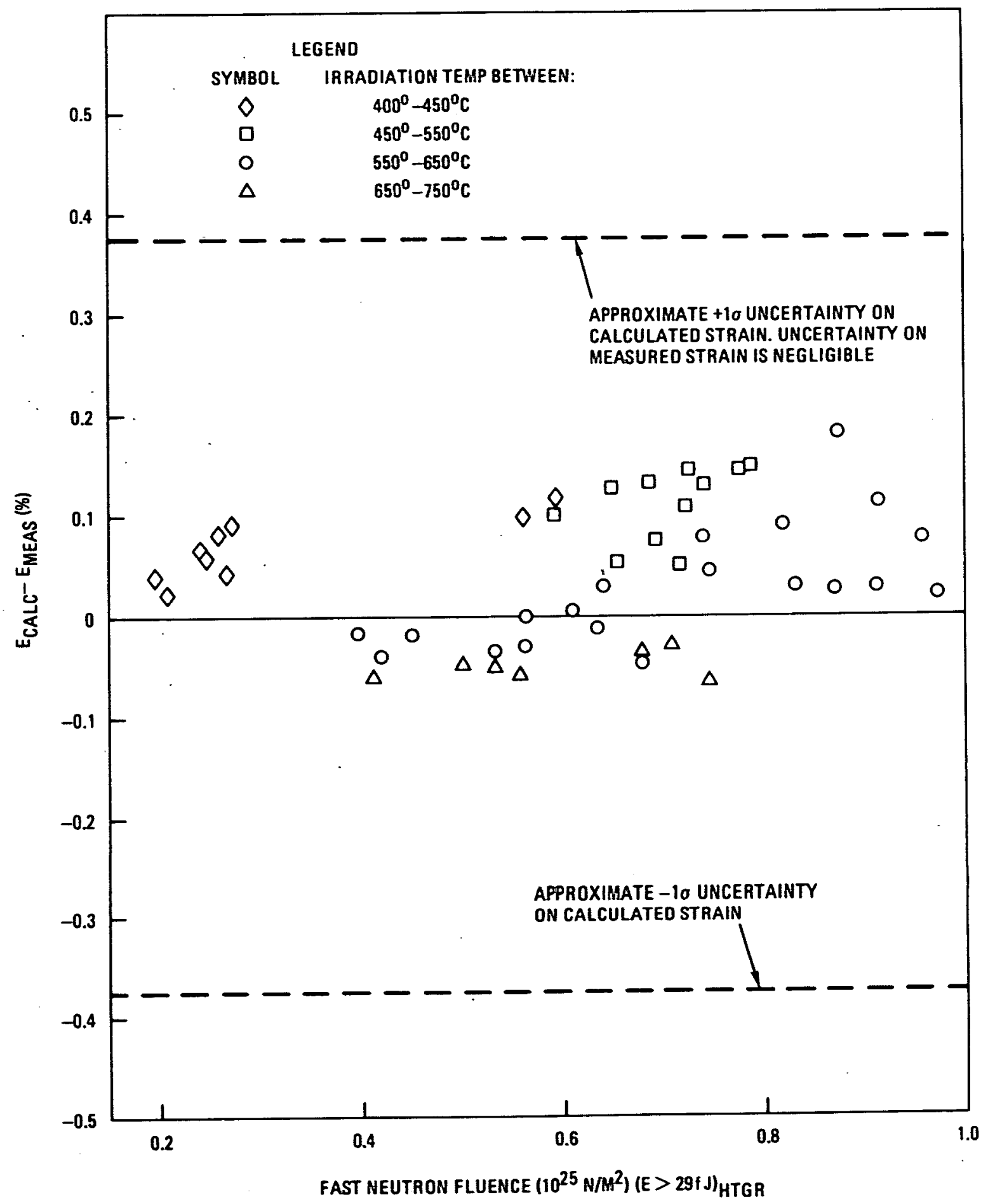

Fig. 5-5. Differences in measured and calculated radial strain for FSV segment 1 fuel elements 


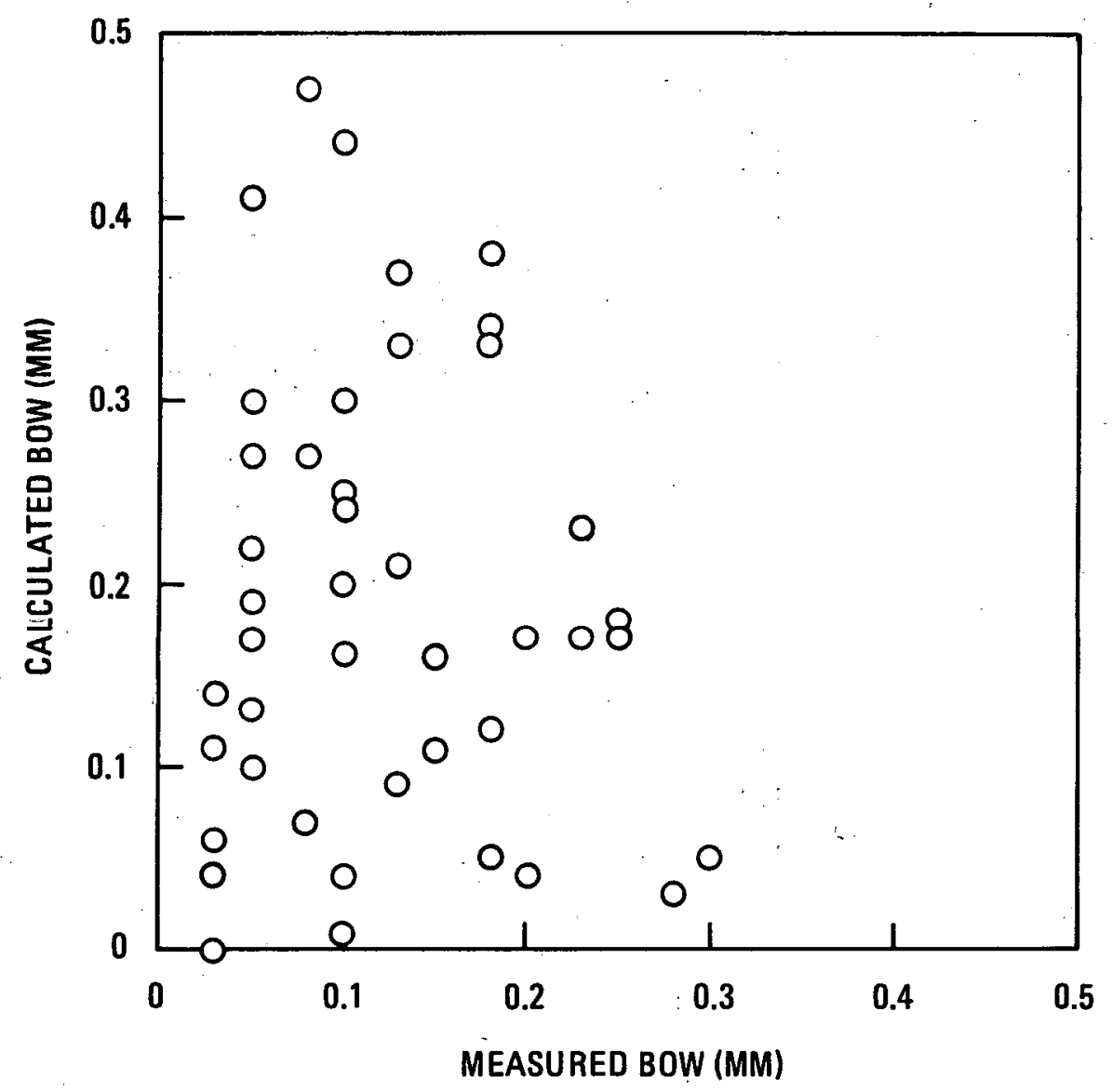

Fig. 5-6. Calculated bow vs measured bow for FSV segment 1 fuel elements 


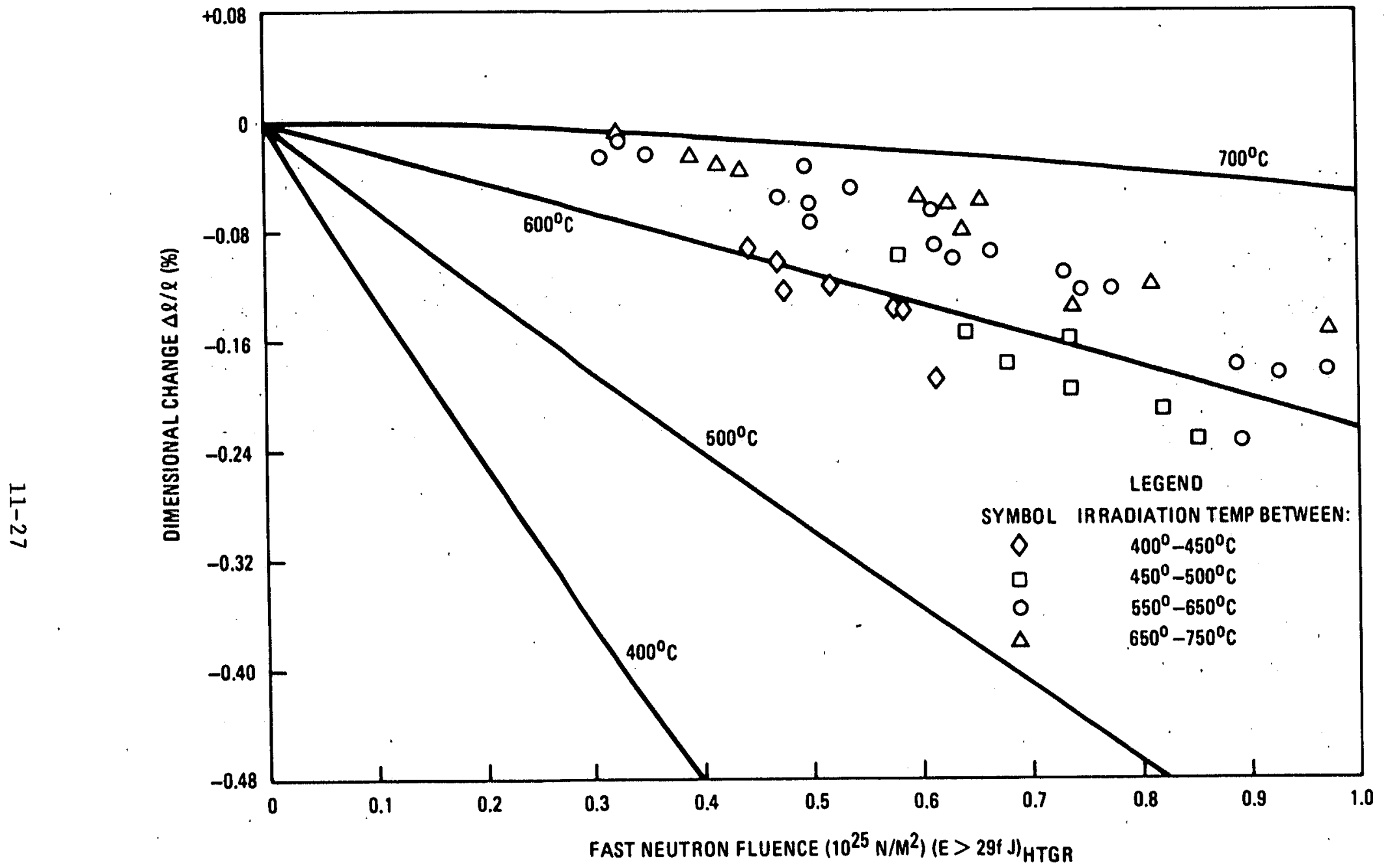

Fig. 5-7. Comparison of axial strains observed In FSV segment 1 fuel elements with the design curves for irradiation-Induced dimensional change of H-327 graphite in the axial orientation 
Fig. 7-1. Dark stain on side face D of element 17:02.F.08 (Mosaic 1 of 4)

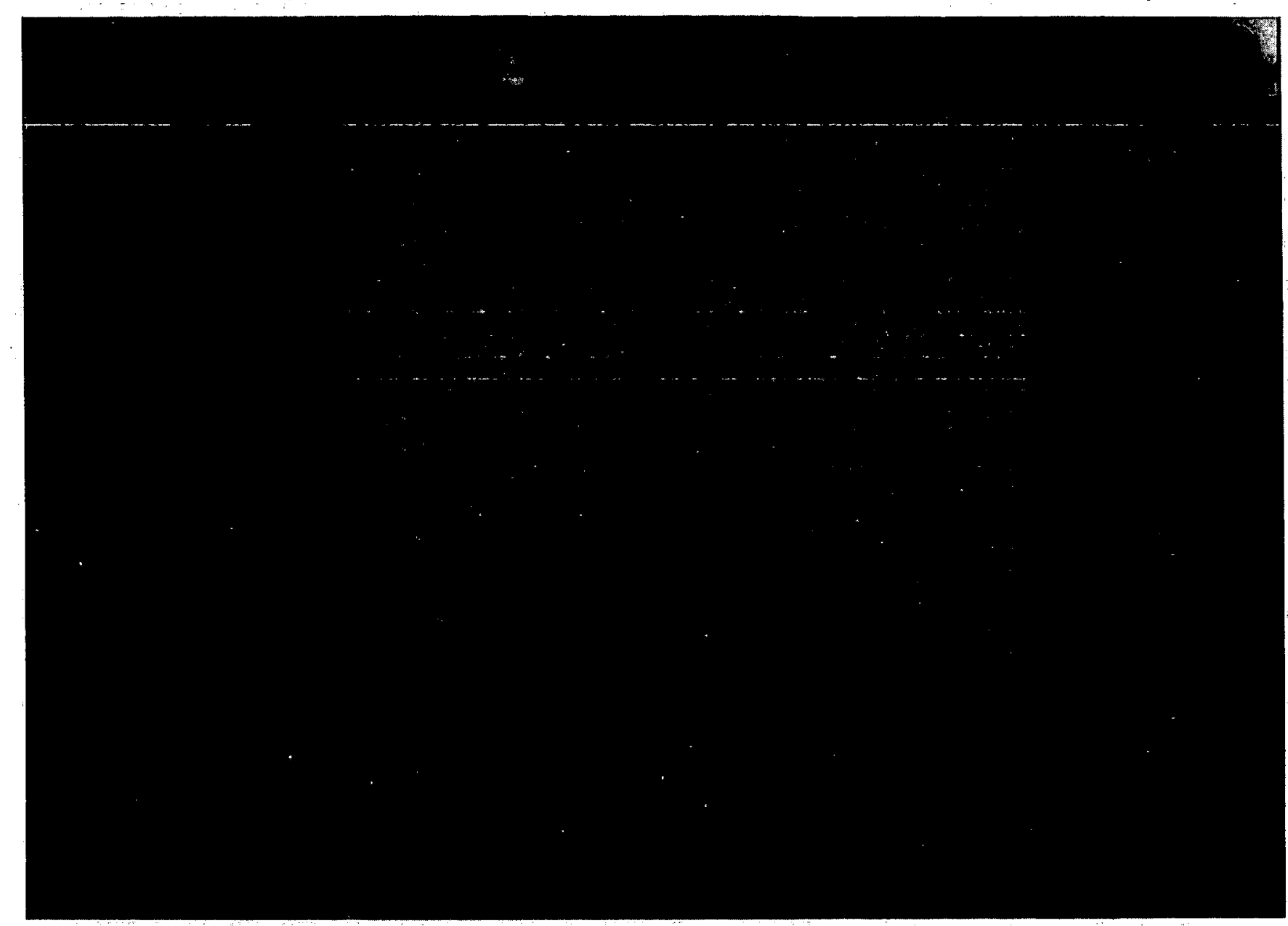


Fig. 7-2. Dark stain on side face D of element 17.02.F.08 (Mosalc 2 of 4) 


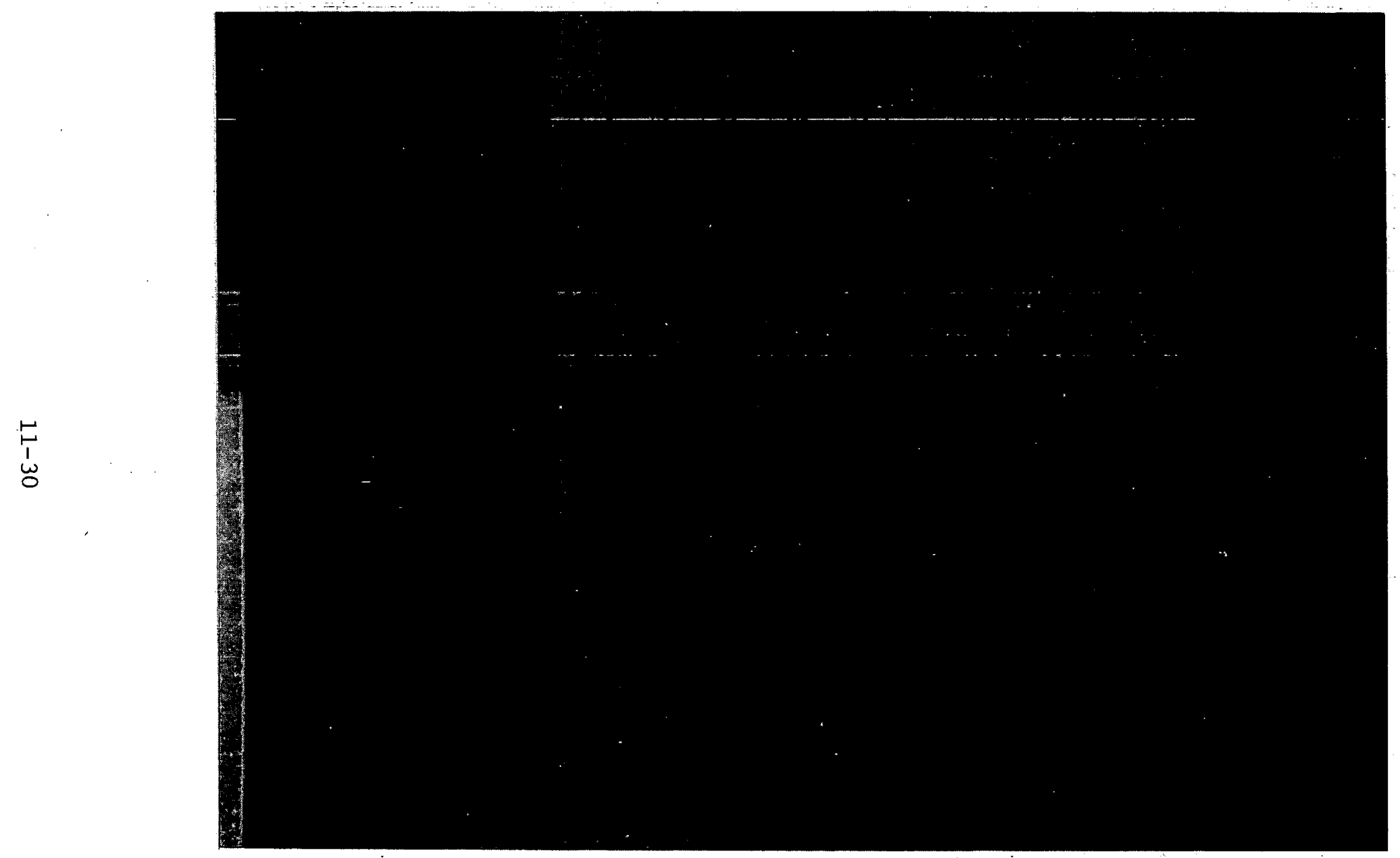

Fig. 7-3. Dark stain on side face D of element 17.02.F.08 (Mosaic 3 of 4) 
Fig. 7-4. Dark stain on side face D of element 17.02.F.08 (mosaic 4 of 4) 



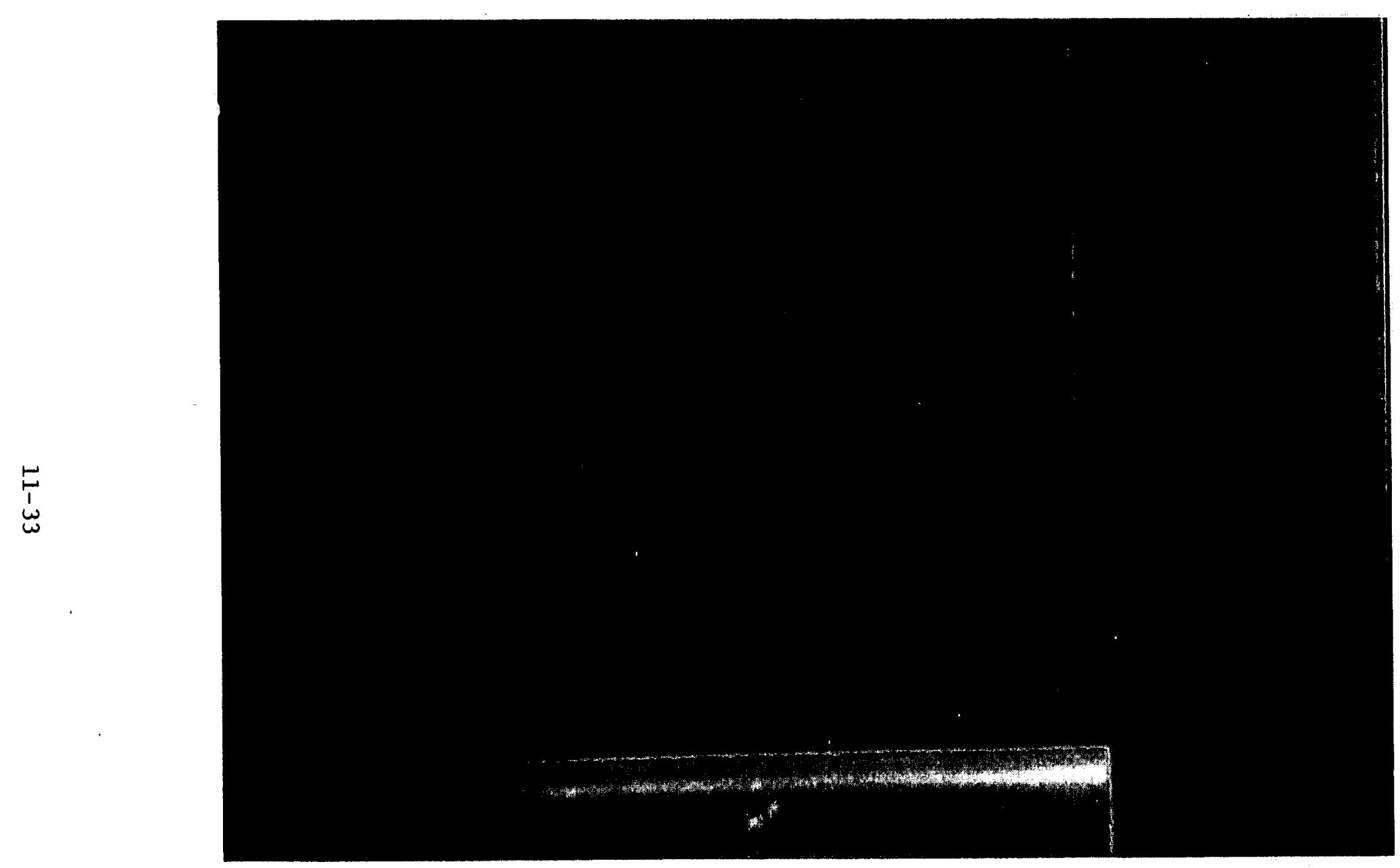

Fig. 7-6. Interface mark on side face A of element 17.01.F.07 


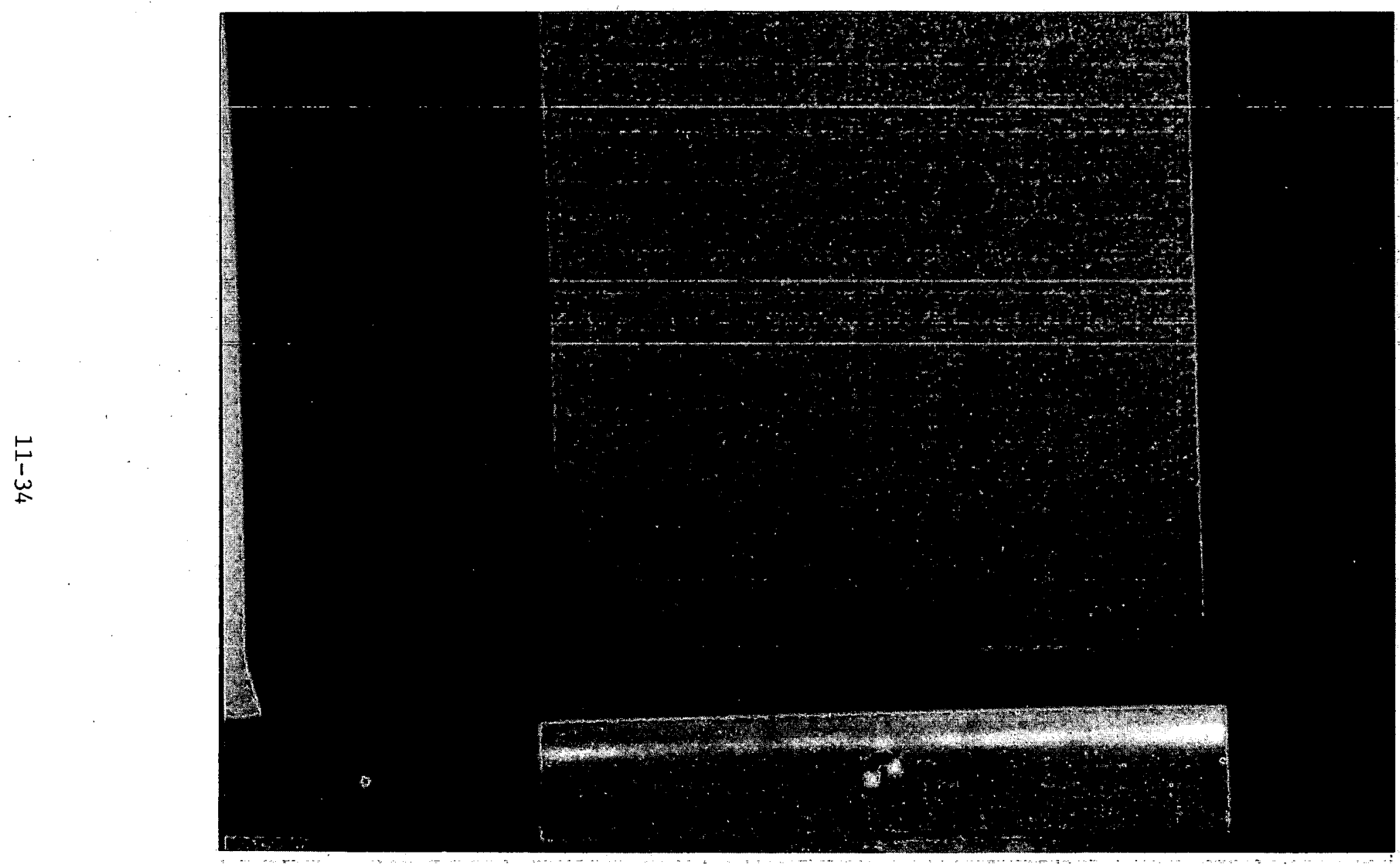

Fig. 7-7. Soot deposits on bottom side face $E$ of element 17.03.F.05 
Fig. 7-8. Scratch on side face $C$ of element 17.06.F.05 (Mosaic 1 of 4) 


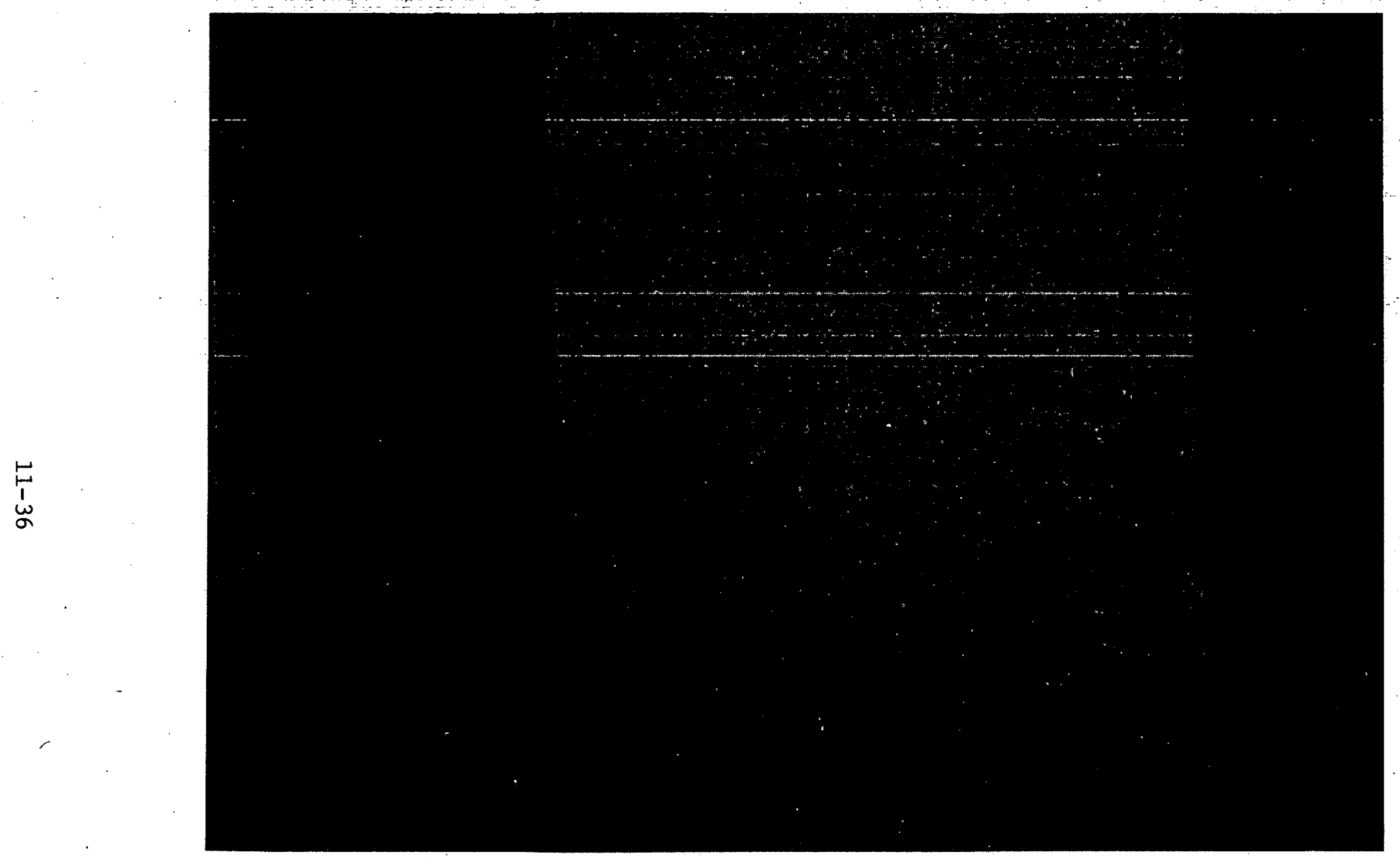

Fig. $7-9, \ldots$ Scratch on side face $C$ of element 17.06.F.05 (Mosaic 2 of 4)

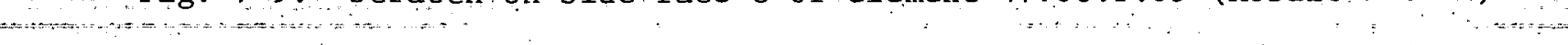




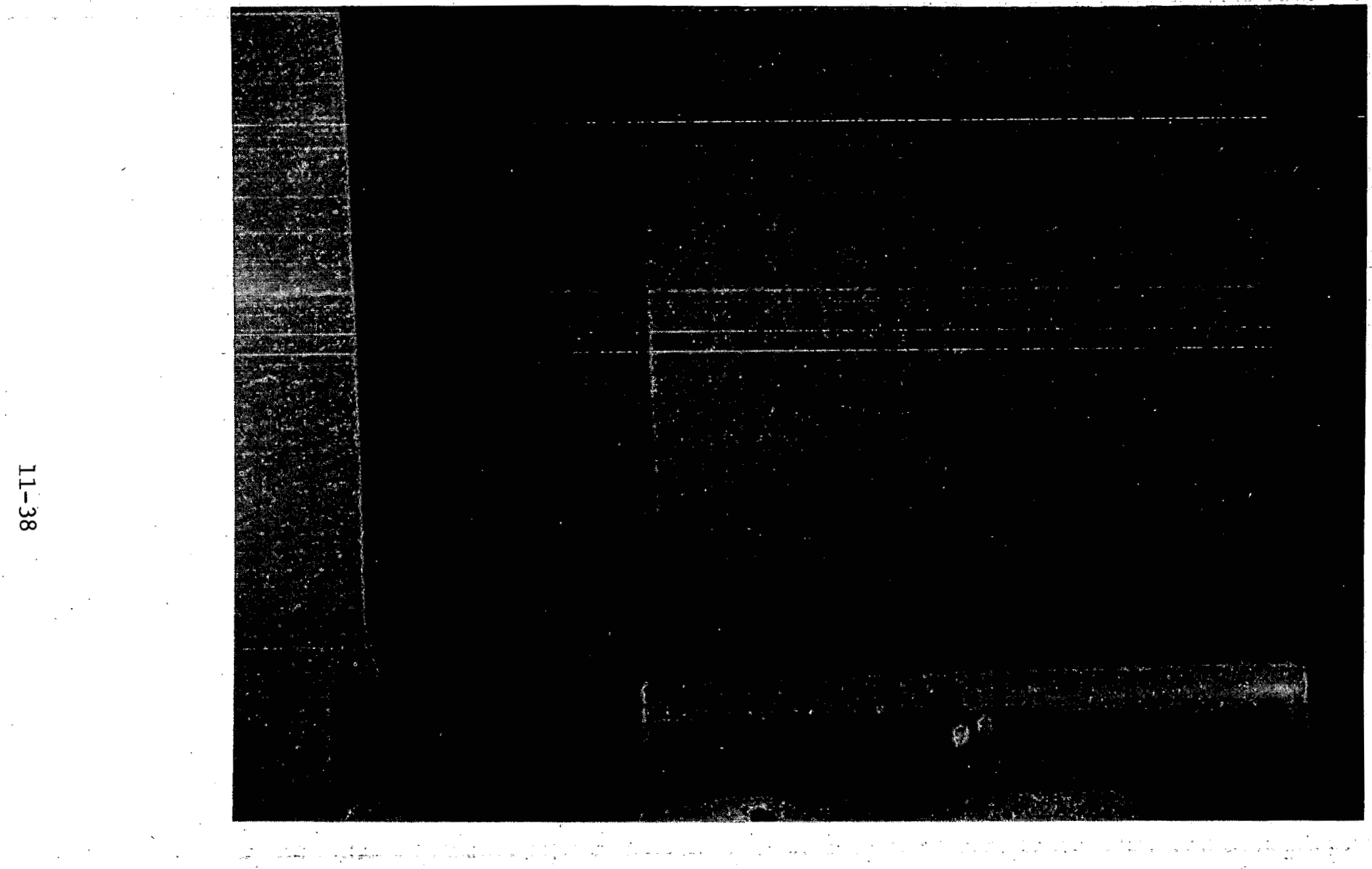

Fig. 7-11. Scratch on side face $\mathrm{C}$ of element 17.06.F.05 (Mosaic 4 of 4) 


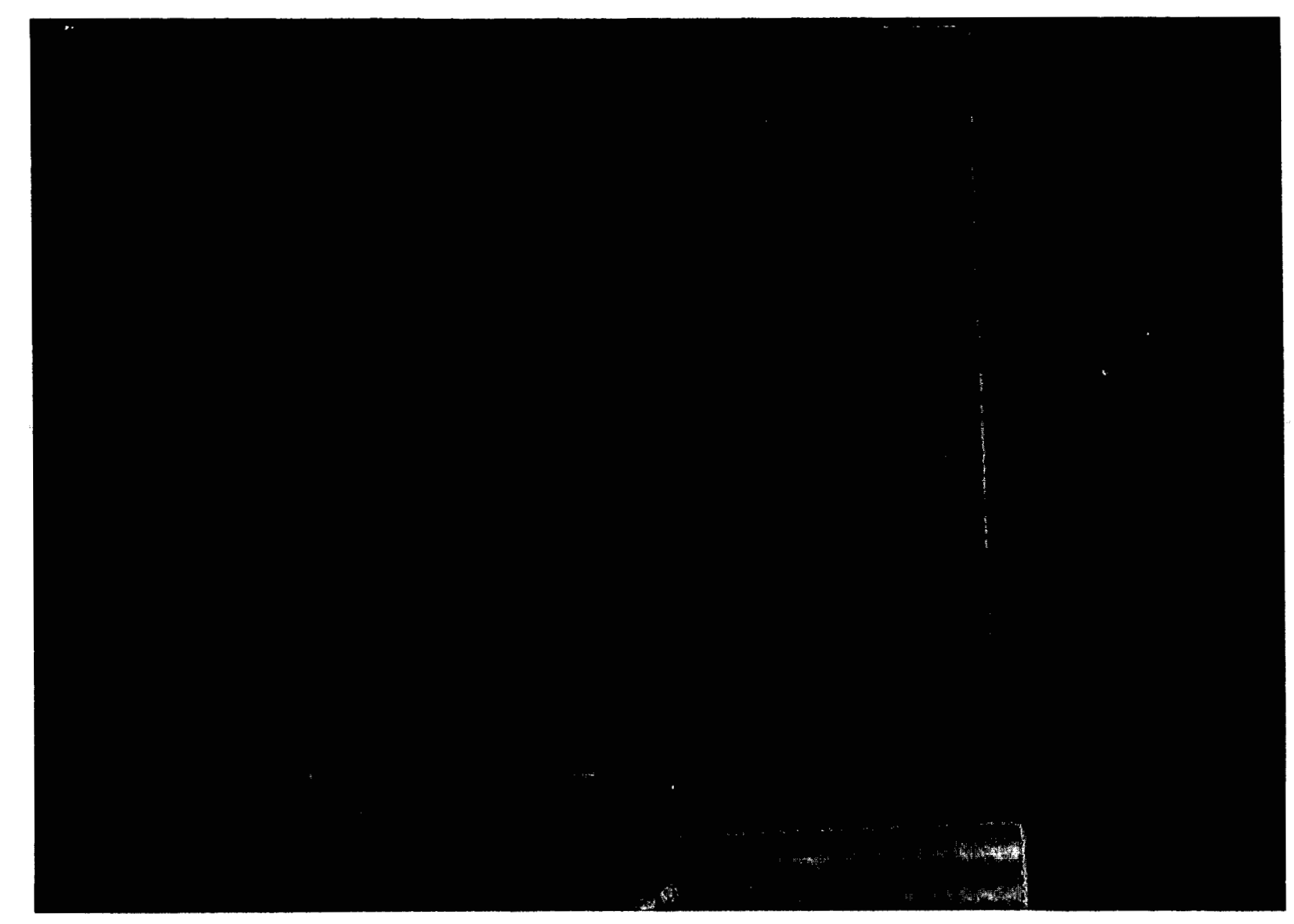

Fig. 7-12. Fingerprints on bottom side face B of element 17.01.F.07 



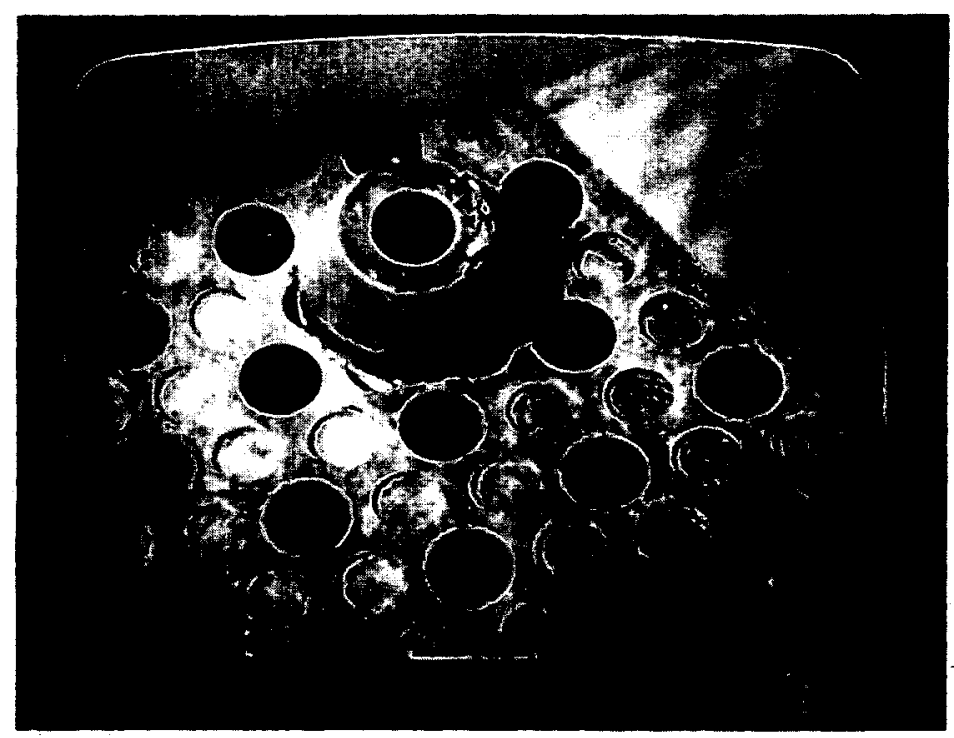

Fig. 7-14. Debris on dowel of element 17.04.F.07

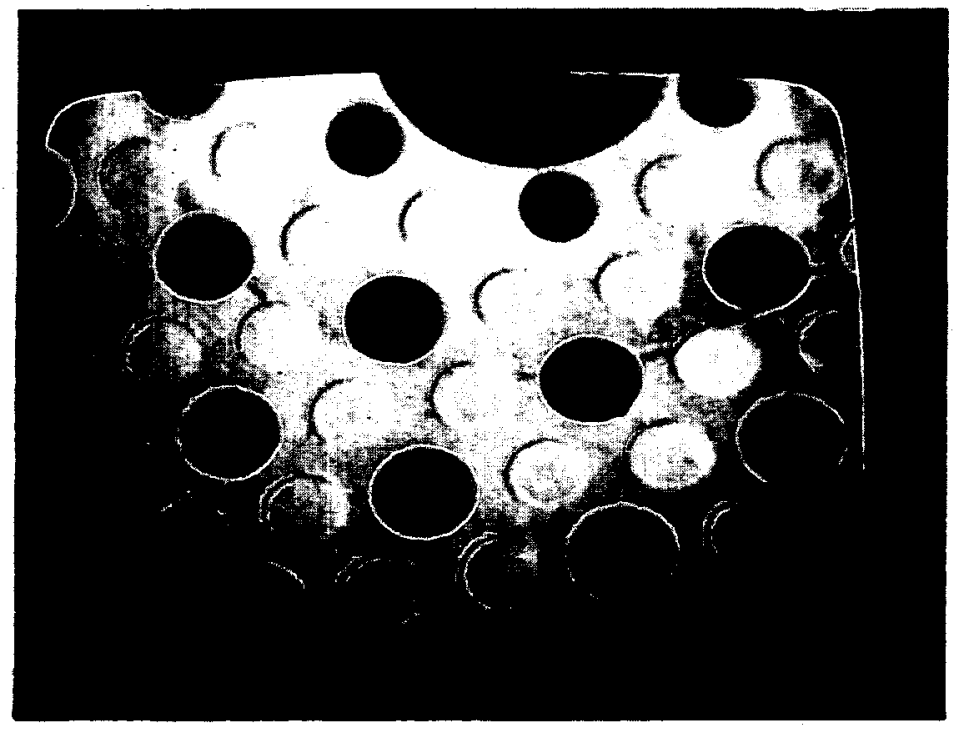

Fig. 7-15. Circle around fuel handling hole on top surface of element $17.07 . \mathrm{F} .07$ 
